Supplementary material for

\title{
Chromene Chromium Carbene Complexes in the Syntheses of Naphthopyran and Naphthopyrandione Units Present in Photochromic Materials and Biologically Active Natural Products
}

\author{
Manish Rawat, Victor Prutyanov and William D.Wulff* \\ Department of Chemistry, Michigan State University, East Lansing, MI 48824
}

\section{Preparation of Imidazolidine 28.}

To a stirred solution of ortho-anisaldehyde $(6.67 \mathrm{~g}, 49.3 \mathrm{mmol})$ in EtOH $(200 \mathrm{~mL})$ was added N,N-dimethylethylenediamine $(5.27 \mathrm{~g}, 60 \mathrm{mmol})$ dropwise. The reaction mixture was stirred at $25^{\circ} \mathrm{C}$ for $24 \mathrm{~h}$ followed by filtration through a pad of $\mathrm{MgSO}_{4}$ and washing with ether. The ether/ethanol solution was concentrated in vacuo and the product was purified by crystallization from hexane to afford the $7.65 \mathrm{~g}(37.1 \mathrm{mmol}, \mathbf{7 5 \%})$ of imidazolidinone $\mathbf{2 8}$ as white crystalline solid. Spectral

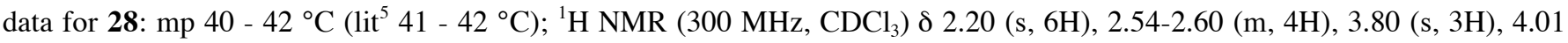
(s, 1H), $6.87(\mathrm{dd}, 1 \mathrm{H}, J=8.4,1.0 \mathrm{~Hz}), 6.95(\mathrm{dt}, 1 \mathrm{H}, \mathrm{J}=7.4,0.9 \mathrm{~Hz}), 7.21(\mathrm{~m}, 1 \mathrm{H}), 7.65(\mathrm{dd}, 1 \mathrm{H}, J=7.4,1.9 \mathrm{~Hz})$.

\section{Synthesis of Anisaldehyde 29.}

To a stirred solution of $\mathbf{2 8}(9.05 \mathrm{~g}, 43.8 \mathrm{mmol})$ in $350 \mathrm{~mL}$ ether at $-40{ }^{\circ} \mathrm{C}$ was added tert-BuLi $(52 \mathrm{~mL}, 87.6 \mathrm{mmol}, 1.7$ M solution in pentane) over $1 \mathrm{~h}$. The reaction mixture was warmed to $-20{ }^{\circ} \mathrm{C}$ and stirred at this temperature for $7 \mathrm{~h}$ then the reaction mixture was cooled to $-78{ }^{\circ} \mathrm{C}$ and transferred by cannula to a solution of $\left(\mathrm{BrCl}_{2} \mathrm{C}\right)_{2}(29 \mathrm{mg}, 87.6 \mathrm{mmol})$ in $150 \mathrm{~mL}$ $\mathrm{Et}_{2} \mathrm{O}$ at $0{ }^{\circ} \mathrm{C}$ over $1 \mathrm{~h}$. The reaction mixture was warmed to $\mathrm{RT}$ over $2 \mathrm{~h}$ and then the mixture was stirred at this temperature for $12 \mathrm{~h}$. The reaction was then quenched carefully with $2 \mathrm{~N} \mathrm{HCl}(750 \mathrm{~mL})$ and stirred at $\mathrm{RT}$ for $1 \mathrm{~h}$. This was followed by extraction of the water layer with $4 \times 200 \mathrm{~mL} \mathrm{CH} \mathrm{Cl}_{2}$. The $\mathrm{CH}_{2} \mathrm{Cl}_{2}$ layer was washed with $200 \mathrm{~mL}$ of saturated ammonium chloride solution. The water layer was then back extracted with 3x100 mL dichloromethane. The combined organic layer was dried and concentrated in vacuo. The product was purified by silica gel column chromatography using (20\% to 40\%) EtOAc : hexane to give $6.5 \mathrm{~g}$ of a mixture of $\mathbf{2 9}$ and $\mathbf{3 0}$ in the ratio of 50:1 (29:30) as an off-white solid. When the reaction was run at 25 ${ }^{\circ} \mathrm{C}$, a 2:1 mixture of 29 and $\mathbf{3 0}$ was obtained. The structure of $\mathbf{2 9}$ was assigned by comparison of the ${ }^{1} \mathrm{H}$ NMR spectrum and $\mathrm{mp}$ with the literature values. ${ }^{5}$ The structure of $\mathbf{3 0}$ was tentatively assigned by the presence of peaks at $\delta=10.36 \mathrm{ppm}$ in the crude ${ }^{1} \mathrm{H}$ NMR spectrum and by two peaks at $m / z=170$ and 172 in a 3:1 ratio in the mass spectrum. Spectral data for 29: $\mathrm{mp} 56-58$ ${ }^{\circ} \mathrm{C}\left(\mathrm{lit}{ }^{5} 57-58{ }^{\circ} \mathrm{C}\right){ }^{1} \mathrm{H}$ NMR $\left(300 \mathrm{MHz}, \mathrm{CDCl}_{3}\right) \delta 3.89(\mathrm{~s}, 3 \mathrm{H}), 6.92(\mathrm{~d}, 1 \mathrm{H}, J=8.2 \mathrm{~Hz}), 7.21(\mathrm{~d}, 1 \mathrm{H}, J=8.5 \mathrm{~Hz}), 7.30(\mathrm{t}, 1 \mathrm{H}, J$ $=8.3 \mathrm{~Hz}), 10.39(\mathrm{~s}, 1 \mathrm{H})$. 


\section{Cleavage of the Ether 29 to ortho-Hydroxybenzaldehyde 23.}

To a stirred solution of $29(6.5 \mathrm{~g}, 30 \mathrm{mmol})$ in $50 \mathrm{~mL} \mathrm{CH}_{2} \mathrm{Cl}_{2}$ was added $40 \mathrm{~mL}$ of $\mathrm{BBr}_{3}\left(1.0 \mathrm{M}\right.$ solution in $\mathrm{CH}_{2} \mathrm{Cl}_{2}$ ) dropwise at $0{ }^{\circ} \mathrm{C}$. The reaction mixture was warmed to RT and stirred for 30 min before quenching with $20 \mathrm{~mL}$ of water. The organic layer was separated and the aqueous layer was extracted with $2 \times 50 \mathrm{~mL}$ of $\mathrm{CH}_{2} \mathrm{Cl}_{2}$. The organic layer was dried over $\mathrm{MgSO}_{4}$, concentrated in vacuo and purified by silica gel column chromatography using ether/hexane (1/10) as eluent to give benzaldehyde 23 (94\% yield) as light green solid. Spectral data for 23 : mp 50-52 ${ }^{\circ} \mathrm{C}\left(1 \mathrm{it}{ }^{5} 51-52{ }^{\circ} \mathrm{C}\right)$; ${ }^{1} \mathrm{H} \mathrm{NMR}(500 \mathrm{MHz}$, $\left.\mathrm{CDCl}_{3}\right) \delta 6.91(\mathrm{~d}, 1 \mathrm{H}, J=8.3 \mathrm{~Hz}), 7.13(\mathrm{dd}, 1 \mathrm{H}, J=7.8,1.0 \mathrm{~Hz}), 7.30(\mathrm{t}, 1 \mathrm{H}, J=8.3 \mathrm{~Hz}) 10.30(\mathrm{~s}, 1 \mathrm{H}), 11.95(\mathrm{~s}, 1 \mathrm{H})$.

\section{Synthesis of bromochromene 21 in Two Steps from Benzaldehyde 23.}

To a stirred solution of 1-bromo-2-methyl-1-propene $(3.87 \mathrm{~g}, 28.67 \mathrm{mmol})$ in $100 \mathrm{~mL}$ ether at $-78{ }^{\circ} \mathrm{C}$ was added tertBuLi (34 mL, $57.34 \mathrm{mmol}$ ) over $15 \mathrm{~min}$. After stirring for $30 \mathrm{~min}$, the reaction mixture was transferred by cannula to a solution of 23 ( $2.62 \mathrm{~g}, 13.03 \mathrm{mmol})$ in $100 \mathrm{~mL}$ ether at $-78{ }^{\circ} \mathrm{C}$. The solution was stirred at $-78{ }^{\circ} \mathrm{C}$ for $2 \mathrm{~h}$ and slowly warmed to RT. The stirring was continued at RT for another $16 \mathrm{~h}$. After $16 \mathrm{~h}$, the reaction was quenched by careful addition of $20 \mathrm{~mL}$ water and $20 \mathrm{~mL}$ saturated ammonium chloride solution. The water layer was extracted with $3 \times 30 \mathrm{~mL}$ ether. The organic layer was then washed with $20 \times 2 \mathrm{~mL}$ of brine, dried over $\mathrm{MgSO}_{4}$ and concentrated in vacuo to give a light green oil. The crude compound so obtained was dissolved in toluene and $\mathrm{TsOH}(50 \mathrm{mg})$ was added. The reaction mixture was heated to 50 ${ }^{\circ} \mathrm{C}$ for $1 \mathrm{~h}$. After $1 \mathrm{~h}$, the reaction mixture was filtered through Celite, concentrated in vacuo and purified by silica gel column chromatography using (1\%) EtOAc:hexane solvent system. This gave a mixture of compounds $\mathbf{2 1}$ and $\mathbf{3 2}$ in the ratio of 10:1 along with a small amount of an unidentified impurity. Further purification was done using Kugelrohr distillation which afforded a $60 \%$ yield of bromochromene $\mathbf{2 1}$ and $\mathbf{3 2}$ in the ratio of 40:1 as colorless liquid (GC). The structure of $\mathbf{3 2}$ was tentatively assigned by two peaks at $\mathrm{m} / z=294$ and 296 in a $100: 98$ ratio in the mass spectrum. Spectral data for 21: ${ }^{1} \mathrm{H}$ NMR $\left(500 \mathrm{MHz}, \mathrm{CDCl}_{3}\right) \delta 1.40(\mathrm{~s}, 6 \mathrm{H}), 5.68(\mathrm{~d}, 1 \mathrm{H}, J=10.0 \mathrm{~Hz}), 6.62(\mathrm{~d}, 1 \mathrm{H}, J=6.6 \mathrm{~Hz}), 6.70(\mathrm{~d}, 1 \mathrm{H}, J=9.0 \mathrm{~Hz}), 6.92(\mathrm{t}$, $1 \mathrm{H}, J=8.1 \mathrm{~Hz}), 7.06(\mathrm{dd}, 1 \mathrm{H}, \mathrm{J}=8.0,1.1 \mathrm{~Hz}) ;{ }^{13} \mathrm{C} \mathrm{NMR}\left(75 \mathrm{MHz}, \mathrm{CDCl}_{3}\right) \delta 127.72,76.29,115.80,121.12,121.14,121.42$, 124.711, 129.44, 132.18, 154.10; mass spectrum (EI) $\mathrm{m} / \mathrm{z}$ (\% rel. int.) $240\left(8,{ }^{81} \mathrm{Br}\right), 238\left(9,{ }^{79} \mathrm{Br}\right), 226\left(12,{ }^{81} \mathrm{Br}\right), 224(18$, $\left.{ }^{79} \mathrm{Br}\right), 225\left(100,{ }^{81} \mathrm{Br}\right), 223\left(83,{ }^{79} \mathrm{Br}\right), 144\left(17,{ }^{81} \mathrm{Br}\right), 115$ (12, $\left.{ }^{79} \mathrm{Br}\right)$. ); IR (neat) 3056, 2976, 2926, 1558, $1444 \mathrm{~cm}^{-1}$; Anal calcd for $\mathrm{C}_{11} \mathrm{H}_{11} \mathrm{BrO}: \mathrm{C}, 55.25 ; \mathrm{H}, 4.64$. Found: $\mathrm{C}, 55.52 ; \mathrm{H}, 4.72$.

\section{Preparation of chromenyl chromium Carbene Complex 20 from Bromochromene 21.}

To a flame-dried $100 \mathrm{~mL}$ round-bottomed flask containing a solution of bromochromene 21 (1.310 g, $5.5 \mathrm{mmol})$ in ether $(25 \mathrm{~mL})$ at $-78{ }^{\circ} \mathrm{C}$ was added tert-BuLi $(6.5 \mathrm{~mL}, 11 \mathrm{mmol}, 1.7 \mathrm{M}$ solution in pentane). The reaction mixture was warmed to $0{ }^{\circ} \mathrm{C}$, stirred at this temperature for $5 \mathrm{~min}$ and cooled to $-78{ }^{\circ} \mathrm{C}$ before it was transferred by cannula to a suspension of $\mathrm{Cr}(\mathrm{CO})_{6}(1.32 \mathrm{~g}, 6.0 \mathrm{mmol})$ in $15 \mathrm{~mL}$ ether maintained at $0{ }^{\circ} \mathrm{C}$. The reaction mixture turned dark red in 5 min. Stirring was continued for $6 \mathrm{~h}$ at room temperature which was followed by removal of ether under vacuum and addition of $10 \mathrm{~mL}$ dichloromethane. $\mathrm{Me}_{3} \mathrm{OBF}_{4}(1.63 \mathrm{~g}, 11 \mathrm{mmol})$ was then added at RT and the reaction mixture was further stirred for $2 \mathrm{~h}$. The 
reaction mixture was then filtered through Celite and concentrated in vacuo. The product was purified by silica gel column chromatography using EtOAc:hexane (5\%) to give $1.75 \mathrm{~g}$ (81\% yield) of carbene complex $\mathbf{2 0}$ as a red crystalline solid. Spectral data for 20: $\mathrm{mp}=95-97^{\circ} \mathrm{C} ;{ }^{1} \mathrm{H}$ NMR $\left(500 \mathrm{MHz}, \mathrm{CDCl}_{3}\right) \delta 1.41(\mathrm{~s}, 6 \mathrm{H}), 4.18(\mathrm{~s}, 3 \mathrm{H}), 5.56(\mathrm{~d}, 1 \mathrm{H}, J=10.2 \mathrm{~Hz}), 5.96$ $(\mathrm{d}, 1 \mathrm{H}, J=10.0 \mathrm{~Hz}), 6.37(\mathrm{~d}, 1 \mathrm{H}, J=7.7 \mathrm{~Hz}), 6.70(\mathrm{dd}, 1 \mathrm{H}, J=8.3,0.9 \mathrm{~Hz}), 7.14(\mathrm{t}, 1 \mathrm{H}, J=7.9 \mathrm{~Hz}) ;{ }^{13} \mathrm{C} \mathrm{NMR}(75 \mathrm{MHz}$, $\left.\mathrm{CDCl}_{3}\right) \delta 27.63,65.66,76.16,110.98,112.93,116.38,118.17,129.06,132.68,152.88,215.85,224.60,357.52$, one sp ${ }^{2} \mathrm{C}$ not located; IR (neat) 2980, 2064, 1934, 1566, $1442 \mathrm{~cm}^{-1}$; mass spectrum (FAB) m/z (\% rel. int.) $394 \mathrm{M}^{+}, 366$ (82), 310 (78), 282 (100), 254 (70), 203 (25). Anal calcd for $\mathrm{C}_{18} \mathrm{H}_{14} \mathrm{CrO}_{7}$ : C, 54.83; H, 3.58. Found: C, 54.53; H, 3.41.

\section{Preparation of Chromenone 25. ${ }^{\mathrm{xxxx}}$}

To a stirred solution of cyclohexane-1,3-dione $27(24.1 \mathrm{~g}, 215 \mathrm{mmol})$ and 1,2-ethanediammoniumacetate in methanol $(300 \mathrm{~mL})$ was added 3-methyl-but-2-enal $(18.11 \mathrm{~g}, 215 \mathrm{mmol})$ over a duration of $5 \mathrm{~h}$. The reaction mixture was then stirred for $24 \mathrm{~h}$ at RT. After $24 \mathrm{~h}$, the reaction mixture was diluted with $500 \mathrm{~mL}$ ether and washed with $50 \mathrm{~mL}$ water and $50 \mathrm{~mL}$ brine. The water layer was extracted with $2 \times 50 \mathrm{~mL}$ ether. The combined organic layer was dried over $\mathrm{MgSO}_{4}$ and concentrated in vacuo. The product was purified by silica gel column chromatography using ether:hexanes (1:7) as eluent to give $30.5 \mathrm{~g}$ of chromenone 25 (78\%) yield. Spectral data for 25 : mp 40-42 ${ }^{\circ} \mathrm{C}\left(\mathrm{lit}^{16} 40-41{ }^{\circ} \mathrm{C}\right) ;{ }^{1} \mathrm{H} \mathrm{NMR}\left(500 \mathrm{MHz}, \mathrm{CDCl}_{3}\right) \delta 1.66(\mathrm{~s}, 6 \mathrm{H})$, 1.85-1.95 (m, 2H), 2.26-2.36 (m, 4H), $5.17(\mathrm{~d}, 1 \mathrm{H}, J=9.3 \mathrm{~Hz}), 6.34(\mathrm{~d}, 1 \mathrm{H}, J=9.8 \mathrm{~Hz})$.

\section{Oxidation of Chromenone 25 to Chromenol 33.}

To a stirred solution of chromenone 25 (3.36 g, $18.8 \mathrm{mmol})$ in $230 \mathrm{~mL}$ dioxane was added a solution of DDQ ( $8.96 \mathrm{~g}$, $39.5 \mathrm{mmol}$ ) in $60 \mathrm{~mL}$ dioxane. The reaction mixture was stirred at RT for $3 \mathrm{~h}$ and then heated to $110{ }^{\circ} \mathrm{C}$ for $42 \mathrm{~h}$. After $42 \mathrm{~h}$, the reaction mixture was cooled to RT and filtered through Celite, concentrated in vacuo and purified by silica gel column chromatography using a gradient of $1 \%$ to $5 \%$ EtOAc in hexane as eluent. The yellow solid so obtained was then crystallized with ether to afford chromenol $\mathbf{3 3}$ as yellow crystalline solid in 53\% yield. Spectral data for 33: mp 113-115 ${ }^{\circ} \mathrm{C}$; (lit ${ }^{6} 114-116$ $\left.{ }^{\circ} \mathrm{C}\right) ;{ }^{1} \mathrm{H}$ NMR $\left(500 \mathrm{MHz}, \mathrm{CDCl}_{3}\right) \delta 1.41(\mathrm{~s}, 6 \mathrm{H}), 4.83(\mathrm{~s}, 1 \mathrm{H}), 5.58(\mathrm{~d}, 1 \mathrm{H}, J=9.7 \mathrm{~Hz}), 6.28(\mathrm{~d}, 1 \mathrm{H}, J=8.3 \mathrm{~Hz}), 6.40(\mathrm{~d}, 1 \mathrm{H}, J$ $=8.8 \mathrm{~Hz}), 6.61(\mathrm{~d}, 1 \mathrm{H}, J=10.2 \mathrm{~Hz}), 6.92(\mathrm{t}, 1 \mathrm{H}, J=7.8 \mathrm{~Hz})$.

\section{Preparation of the Chromene Triflate 24.}

To a stirred solution of $\mathbf{3 3}(200 \mathrm{mg}, 1.13 \mathrm{mmol})$ in $10 \mathrm{~mL} \mathrm{CH}_{2} \mathrm{Cl}_{2}$ at $0{ }^{\circ} \mathrm{C}$ was added di-isopropylethyl amine (235 $\mu \mathrm{L}$, $1.35 \mathrm{mmol})$ and $\mathrm{Tf}_{2} \mathrm{O}(208 \mu \mathrm{L}, 1.13 \mathrm{mmol})$. The reaction mixture was stirred at $0{ }^{\circ} \mathrm{C}$ for $2 \mathrm{~h}$. After $2 \mathrm{~h}$, the reaction mixture was concentrated in vacuo, purified by silica gel column chromatography using 5\% EtOAc in hexane as the solvent system to give compound 24 (324 mg, 93\% yield) as a colorless oil. Spectral data for 24: ${ }^{1} \mathrm{H}$ NMR $\left(500 \mathrm{MHz}, \mathrm{CDCl}_{3}\right) \delta 1.43(\mathrm{~s}, 6 \mathrm{H})$, $5.76(\mathrm{~d}, 1 \mathrm{H}, J=8.2 \mathrm{~Hz}), 6.51(\mathrm{~d}, 1 \mathrm{H}, J=9.7 \mathrm{~Hz}), 6.78(\mathrm{~d}, 2 \mathrm{H}, J=7.8 \mathrm{~Hz}), 7.11(\mathrm{t}, 1 \mathrm{H}, J=8.3 \mathrm{~Hz}) ;{ }^{13} \mathrm{C} \mathrm{NMR}(75 \mathrm{MHz}$, $\left.\mathrm{CDCl}_{3}\right) \delta 27.71,76.72,113.28,115.01,115.17,116.48,118.62(\mathrm{q}, J=319 \mathrm{~Hz}), 129.04,132.99,145.17,154.31$. IR (neat) 
2980, 2937, 1637, 1616, $1568 \mathrm{~cm}^{-1}$; mass spectrum (FAB) $\mathrm{m} / z$ (\% rel. int.) $308 \mathrm{M}^{+}$(5), 293 (24), 256 (5), 161 (13), 160 (100), 159 (17), 132 (13). Anal calcd for $\mathrm{C}_{12} \mathrm{H}_{11} \mathrm{~F}_{3} \mathrm{O}_{4} \mathrm{~S}$ : C, 46.75; H, 3.60. Found: C, 46.52; $\mathrm{H}, 3.35$.

\section{Conversion of the Chromenyl Triflate 24 to Chromene Stannane 34 by Cross-Coupling with Hexamethylditin.}

To a mixture of hexamethylditin $(675 \mathrm{mg}, 2.17 \mathrm{mmol}), \mathrm{Pd}\left(\mathrm{PPh}_{3}\right)_{4}(50 \mathrm{mg}, 0.04 \mathrm{mmol}) \mathrm{dppf}(54 \mathrm{mg}, 0.10 \mathrm{mmol})$ and $\mathrm{LiCl}(552 \mathrm{mg}, 13.02 \mathrm{mmol})$ was added a solution of compound 24 (670 mg, $2.17 \mathrm{mmol})$ in $15 \mathrm{~mL}$ dioxane. The solution was deoxygenated using the freeze-thaw method ( -196 to $25^{\circ} \mathrm{C}, 3$ cycles). The reaction mixture was then stirred at $110{ }^{\circ} \mathrm{C}$ for 3 days. After 3 days, the reaction mixture was filtered through Celite and washed using hexane. The solvent was then concentrated in vacuo to give a mixture of compounds which consisted of $\mathbf{3 4}$ and $\mathbf{3 5}$ (84:7) along with triphenylphosphine and small amounts of other impurities. This mixture was loaded onto a silica gel column and eluted with hexane and EtOAc (20:1) to give a mixture of compounds but with the amounts of $\mathbf{3 4}$ and $\mathbf{3 5}$ enhanced and in the same ratio. The following ${ }^{1} \mathrm{H}$ NMR data for 34 was extracted from the ${ }^{1} \mathrm{H}$ NMR spectrum of the mixture. Spectral data for $34:{ }^{1} \mathrm{H} \mathrm{NMR}(500 \mathrm{MHz}, \mathrm{CDCl} 3) \delta 0.30$ $(\mathrm{s}, 9 \mathrm{H}), 1.41(\mathrm{~s}, 6 \mathrm{H}), 5.61(\mathrm{~d}, 1 \mathrm{H}, J=9.6 \mathrm{~Hz}), 6.28(\mathrm{~s}, 1 \mathrm{H}, J=9.0 \mathrm{~Hz}), 6.74(\mathrm{dd}, 1 \mathrm{H}, J=8.0,0.5 \mathrm{~Hz}), 6.94(\mathrm{dd}, 1 \mathrm{H}, J=7.2,0.6$ $\mathrm{Hz}), 7.06(\mathrm{t}, 1 \mathrm{H}, \mathrm{J}=7.4 \mathrm{~Hz})$.

\section{Conversion of the Chromenyl Triflate 24 to the Bromochromene 21 without Isolation of 34.}

To a mixture of hexamethylditin $(675 \mathrm{mg}, 2.17 \mathrm{mmol}), \mathrm{Pd}\left(\mathrm{PPh}_{3}\right)_{4}(50 \mathrm{mg}, 0.04 \mathrm{mmol}), \mathrm{dppf}(54 \mathrm{mg}, 0.10 \mathrm{mmol})$ and $\mathrm{LiCl}(552 \mathrm{mg}, 13.02 \mathrm{mmol})$ was added solution of compound 24 (670 mg, $2.17 \mathrm{mmol})$ in $15 \mathrm{~mL}$ dioxane. The solution was deoxygenated using freeze-thaw method $\left(-196\right.$ to $25^{\circ} \mathrm{C}, 3$ cycles). The reaction mixture was then stirred at $110{ }^{\circ} \mathrm{C}$ for 3 days. After 3 days, the reaction mixture was filtered through Celite and washed with hexane. The solvent was then evaporated using a rotary evaporater to give an oily residue, which was dissolved in THF and solid NBS (579 mg, 3.25 mmol) was added. After stirring for $1 \mathrm{~h}$ at $\mathrm{RT}$, the reaction mixture was concentrated in vacuo and purified by flash silica gel column chromatography (5\%) ether in pentane to give 5-bromo chromene 21 as a colorless oil in $75 \%$ yield. The compound from this reaction had spectral data identical with that reported above.

\section{Synthesis of the TBS-Protected Naphthopyran 36b from Carbene Complex 20 and Phenylacetylene.}

To a flame-dried $25 \mathrm{~mL}$ flask with the 14/20 joint replaced by a high-vacuum threaded Teflon stopcock was added chromene carbene complex 20 (100 mg, $0.254 \mathrm{mmol}), 5 \mathrm{~mL}$ benzene, phenyl acetylene (56 $\mu \mathrm{L}, 0.508 \mathrm{mmol}), \mathrm{TBSCl}(115 \mathrm{mg}$, $0.762 \mathrm{mmol})$ and $\mathrm{N}, \mathrm{N}$-diisopropylethylamine $(55 \mu \mathrm{L}, 1.270 \mathrm{mmol})$. The system was deoxygenated by the freeze-pump-thaw method ( -196 to $25^{\circ} \mathrm{C}, 3$ cycles). The flask was back-filled with Ar at room temperature and sealed. The reaction mixture was then stirred at $50{ }^{\circ} \mathrm{C}$ for $24 \mathrm{~h}$ and then at RT for another $24 \mathrm{~h}$. The reaction mixture was opened to air and allowed to stir for $12 \mathrm{~h}$. The reaction mixture was filtered through Celite, concentrated in vacuo and the product was purified by silica gel column chromatography with 5\% EtOAc in hexanes to give naphthopyran $36 \mathbf{b}$ (31 mg) in $27 \%$ yield as a colorless liquid. 
Spectral data for 36b: ${ }^{1} \mathrm{H}$ NMR $\left(500 \mathrm{MHz}, \mathrm{CDCl}_{3}\right) \delta-0.41(\mathrm{~s}, 6 \mathrm{H}), 0.97(\mathrm{~s}, 9 \mathrm{H}), 1.47(\mathrm{~s}, 6 \mathrm{H}), 3.92(\mathrm{~s}, 3 \mathrm{H}), 5.58,(\mathrm{~d}, 1 \mathrm{H}, J=$ $10.2 \mathrm{~Hz}), 6.83(\mathrm{~s}, 1 \mathrm{H}), 7.04(\mathrm{~d}, 1 \mathrm{H}, J=9.1 \mathrm{~Hz}), 7.27-7.34(\mathrm{~m}, 1 \mathrm{H}), 7.40(\mathrm{t}, 2 \mathrm{H}, J=7.8 \mathrm{~Hz}), 7.63(\mathrm{dd}, 2 \mathrm{H}, J=7.2,1.4 \mathrm{~Hz}), 7.76$ $(\mathrm{d}, 1 \mathrm{H}, J=10.2 \mathrm{~Hz}), 7.98(\mathrm{~d}, 1 \mathrm{H}, J=9.1 \mathrm{~Hz}) ;{ }^{13} \mathrm{C} \mathrm{NMR}\left(75 \mathrm{MHz}, \mathrm{CDCl}_{3}\right) \delta-4.36,18.45,26.08,27.86,55.85,74.72,109.75$, $114.40,118.14,122.47,123.32,124.61,125.19,125.89,126.66,127.11,128.11,130.25,140.16,142.01,151.57,151.92 ;$ IR (neat) 2955, 2930, 2856, 1452, $1381 \mathrm{~cm}^{-1}$; mass spectrum (EI) $\mathrm{m} / \mathrm{z}$ (\% rel. int.) $447 \mathrm{M}^{+}+1$ (16), $446 \mathrm{M}^{+}$(9), 422 (27), 432 (100), 417 (6), 390 (3). Anal calcd for $\mathrm{C}_{28} \mathrm{H}_{34} \mathrm{O}_{3} \mathrm{Si}: \mathrm{C}, 75.29$; H, 7.67. Found: C, 74.99; H, 7.40.

\section{Synthesis of the TMS-Protected Naphthopyran 36c from Carbene Complex 20 and Phenylacetylene.}

To a flame-dried $10 \mathrm{~mL}$ flask with the 14/20 joint replaced by a high-vacuum threaded Teflon stopcock was added chromene carbene complex 20 ( $25 \mathrm{mg}, 0.063 \mathrm{mmol}), 1.2 \mathrm{~mL}$ benzene, phenyl acetylene (14 $\mu \mathrm{L}, 0.126 \mathrm{mmol})$, TMSCl (24 $\mu \mathrm{L}$, $0.189 \mathrm{mmol})$ and $\mathrm{N}, \mathrm{N}$-diisopropylethylamine $(55 \mu \mathrm{L}, 0.315 \mathrm{mmol})$. The system was deoxygenated by the freeze-pump-thaw method ( -196 to $25^{\circ} \mathrm{C}, 3$ cycles). The flask was back-filled with argon at RT and sealed. The reaction mixture was then stirred at $50{ }^{\circ} \mathrm{C}$ for $24 \mathrm{~h}$ and then at RT for another $24 \mathrm{~h}$. The reaction mixture was opened to air and allowed to stir for $12 \mathrm{~h}$. The reaction mixture was filtered through Celite, concentrated in vacuo and the product was purified by silica gel column chromatography with $5 \%$ EtOAc in hexanes to give naphthopyran 36c $(16.5 \mathrm{mg})$ in $65 \%$ yield as colorless liquid. Spectral data for 36c: ${ }^{1} \mathrm{H}$ NMR $\left(500 \mathrm{MHz}, \mathrm{CDCl}_{3}\right) \delta-0.16(\mathrm{~s}, 9 \mathrm{H}), 1.47(\mathrm{~s}, 6 \mathrm{H}), 3.91(\mathrm{~s}, 3 \mathrm{H}), 5.58(\mathrm{~d}, 1 \mathrm{H}, J=10.1 \mathrm{~Hz}), 6.79(\mathrm{~s}, 1 \mathrm{H})$, $7.04(\mathrm{~d}, 1 \mathrm{H}, J=9.6 \mathrm{~Hz}), 7.26-7.34(\mathrm{~m}, 1 \mathrm{H}), 7.41(\mathrm{t}, 2 \mathrm{H}, J=7.5 \mathrm{~Hz}), 7.58(\mathrm{dd}, 2 \mathrm{H}, J=6.9,1.6 \mathrm{~Hz}), 7.75(\mathrm{~d}, 1 \mathrm{H}, J=10.2 \mathrm{~Hz})$,

$7.85(\mathrm{~d}, 1 \mathrm{H}, J=9.3 \mathrm{~Hz}) ;{ }^{13} \mathrm{C} \mathrm{NMR}\left(75 \mathrm{MHz}, \mathrm{CDCl}_{3}\right) \delta 0.32,27.35,55.87,74.76,109.53,114.51,118.50,112.48,123.29$, $124.64,124.87,125.89,126.75,127.18,128.20,130.17,140.09,142.43,151.59,151.99 ; \quad$ IR (neat) 2965, 2939, 2848, 1452, $1366 \mathrm{~cm}^{-1}$; mass spectrum (EI) $\mathrm{m} / z$ (\% rel. int.) $405 \mathrm{M}^{+}+1$ (11), $404 \mathrm{M}^{+}$(36), 391 (23), 390 (100), 376 (6), 375 (15), 374 (5), 302 (5). Anal calcd for $\mathrm{C}_{25} \mathrm{H}_{28} \mathrm{O}_{3} \mathrm{Si}: \mathrm{C}, 74.22 ; \mathrm{H}, 6.98$. Found: $\mathrm{C}, 73.99 ; \mathrm{H}, 7.39$.

\section{Synthesis of the Acetylated Naphthopyran 36d from Carbene Complex 20 and Phenylacetylene.}

To a flame-dried $25 \mathrm{~mL}$ flask with the 14/20 joint replaced by a high-vacuum threaded Teflon stopcock was added chromene carbene complex $20(100 \mathrm{mg}, 0.254 \mathrm{mmol})$, benzene $(5.0 \mathrm{~mL})$, phenyl acetylene $(56 \mu \mathrm{L}, 0.508 \mathrm{mmol})$, acetic anhydride (72 $\mu \mathrm{L}, 0.762 \mathrm{mmol})$ and $\mathrm{N}, \mathrm{N}$-diisopropylethylamine $(221 \mu \mathrm{L}, 1.270 \mathrm{mmol})$. The system was deoxygenated by the freeze-pump-thaw method (-196 to $25{ }^{\circ} \mathrm{C}, 3$ cycles). The flask was back-filled with argon at RT and sealed. The reaction mixture was then stirred at $50{ }^{\circ} \mathrm{C}$ for $24 \mathrm{~h}$ and then at RT for another $24 \mathrm{~h}$. The reaction mixture was opened to air and allowed to stir for $12 \mathrm{~h}$. The reaction mixture was filtered through Celite, concentrated in vacuo and the product was purified by silica gel column chromatography with $15 \%$ EtOAc in hexane to give naphthopyran $36 \mathbf{d}(58 \mathrm{mg})$ in $58 \%$ yield as white solid. Spectral data for 36d: $\mathrm{mp}=164-166{ }^{\circ} \mathrm{C} ; \quad{ }^{1} \mathrm{H}$ NMR $\left(500 \mathrm{MHz}, \mathrm{CDCl}_{3}\right) \delta 1.45(\mathrm{~s}, 6 \mathrm{H}), 2.15(\mathrm{~s}, 3 \mathrm{H}), 3.95(\mathrm{~s}, 3 \mathrm{H}), 5.60(\mathrm{~d}, 1 \mathrm{H}, J$ $=10.2 \mathrm{~Hz}), 6.83(\mathrm{~s}, 1 \mathrm{H}), 7.09(\mathrm{~d}, 1 \mathrm{H}, J=8.8 \mathrm{~Hz}), 7.31-7.37(\mathrm{~m}, 1 \mathrm{H}), 7.42(\mathrm{t}, 2 \mathrm{H}, J=7.6 \mathrm{~Hz}), 7.50(\mathrm{dd}, 2 \mathrm{H}, J=7.6,1.4 \mathrm{~Hz})$, $7.59(\mathrm{~d}, 1 \mathrm{H}, J=8.8 \mathrm{~Hz}), 7.72(\mathrm{~d}, 1 \mathrm{H}, J=10.2 \mathrm{~Hz}) ;{ }^{13} \mathrm{C} \mathrm{NMR}\left(75 \mathrm{MHz}, \mathrm{CDCl}_{3}\right) \delta 20.71,27.19,55.71,74.86,108.10,115.15$, 
$120.01,122.30,122.71,123.06,124.45,127.37,127.74,128.14,128.38,128.96,137.22,138.18,152.16,154.89,169.65 ;$ IR (neat) $3059,3014,2970,2926,1759,1622 \mathrm{~cm}^{-1}$; mass spectrum (EI) $\mathrm{m} / z$ (\% rel. int.) $375 \mathrm{M}^{+}+1(23), 374 \mathrm{M}^{+}(77), 360(11)$, 318 (100), 302 (26). Anal calcd for $\mathrm{C}_{24} \mathrm{H}_{22} \mathrm{O}_{4}$ : C, 76.99; H, 5.92. Found: C, 77.09; H, 6.16.

\section{Synthesis of the MOM-Protected Naphthopyran 36e from Carbene Complex 20 and Phenylacetylene.}

To a flame-dried $25 \mathrm{~mL}$ flask with the 14/20 joint replaced by a high-vacuum threaded Teflon stopcock was added chromene carbene complex $20(100 \mathrm{mg}, 0.254 \mathrm{mmol})$ in benzene $(5.0 \mathrm{~mL})$, phenyl acetylene $(56 \mu \mathrm{L}, 0.508 \mathrm{mmol}), \mathrm{MOCl}(58$ $\mu \mathrm{L}, 0.762 \mathrm{mmol})$ and $\mathrm{N}, \mathrm{N}$-diisopropylethylamine $(221 \mu \mathrm{L}, 1.270 \mathrm{mmol})$ in benzene $(5.0 \mathrm{~mL})$. The system was deoxygenated by the freeze-pump-thaw method $\left(-196\right.$ to $25^{\circ} \mathrm{C}, 3$ cycles). The flask was back-filled with argon at $25{ }^{\circ} \mathrm{C}$ and sealed. The reaction mixture was then stirred at $50{ }^{\circ} \mathrm{C}$ for $24 \mathrm{~h}$ and then at $\mathrm{RT}$ for another $24 \mathrm{~h}$. The reaction mixture was opened to air and allowed to stir for $12 \mathrm{~h}$. The reaction mixture was filtered through Celite, concentrated in vacuo and the product was purified by silica gel column chromatography using $5 \%$ EtOAc in hexane to give naphthopyran 36e (57 mg) in $60 \%$ yield as a colorless

liquid. Spectral data for 36e: ${ }^{1} \mathrm{H}$ NMR $\left(500 \mathrm{MHz}^{\mathrm{C}} \mathrm{CDCl}_{3}\right) \delta 1.46(\mathrm{~s}, 6 \mathrm{H}), 3.17(\mathrm{~s}, 3 \mathrm{H}), 3.93(\mathrm{~s}, 3 \mathrm{H}), 4.7$ (s, $\left.2 \mathrm{H}\right), 5.58(\mathrm{~d}, 1 \mathrm{H}, J$ $=10.2 \mathrm{~Hz}), 6.80(\mathrm{~s}, 1 \mathrm{H}), 7.10(\mathrm{~d}, 1 \mathrm{H}, J=9.3 \mathrm{~Hz}), 7.28-7.37(\mathrm{~m}, 1 \mathrm{H}), 7.43(\mathrm{t}, 2 \mathrm{H}, J=7.5 \mathrm{~Hz}), 7.62(\mathrm{dd}, 2 \mathrm{H}, J=7.5,1.4 \mathrm{~Hz})$, $7.73(\mathrm{~d}, 1 \mathrm{H}, J=10.1 \mathrm{~Hz}), 8.06(\mathrm{~d}, 1 \mathrm{H}, J=9.0 \mathrm{~Hz}) ;{ }^{13} \mathrm{C} \mathrm{NMR}\left(75 \mathrm{MHz}, \mathrm{CDCl}_{3}\right) \delta 27.25,55.74,57.55,74.78,99.71,108.92$, $114.79,119.33,122.47,123.17,124.15,126.11,126.96,127.38,127.60,128.34,129.63,139.25,143.87,152.12,153.43 ;$ IR (neat) $2974,2934,1613,1591,1371 \mathrm{~cm}^{-1}$; mass spectrum (EI) $\mathrm{m} / z$ (\% rel. int.) $377 \mathrm{M}^{+}+1(29), 376 \mathrm{M}^{+}$(100), 363 (12), 332 (40), 330 (17), 301 (11), 300 (14). Anal calcd for $\mathrm{C}_{24} \mathrm{H}_{24} \mathrm{O}_{4}$ : C,76.57; H, 6.43. Found: C, 76.75; H, 6.29.

\section{Synthesis of the TMS-Protected Naphthopyran 38c from Carbene Complex 20 and 1-Pentyne.}

To a flame-dried $10 \mathrm{~mL}$ flask with the 14/20 joint replaced by a high-vacuum threaded Teflon stopcock was added chromene carbene complex 20 (25 mg, $0.063 \mathrm{mmol})$, benzene (1.2 mL), 1-pentyne (13 $\mu \mathrm{L}, 0.126 \mathrm{mmol}), \mathrm{TMSCl}(24 \mu \mathrm{L}, 0.189$ mmol) and N,N-diisopropylethylamine $(55 \mu \mathrm{L}, 0.315 \mathrm{mmol})$. The system was deoxygenated by the freeze-pump-thaw method (-196 to $25^{\circ} \mathrm{C}, 3$ cycles). The flask was back-filled with argon at $25^{\circ} \mathrm{C}$ and sealed. The reaction mixture was then stirred at $50{ }^{\circ} \mathrm{C}$ for $24 \mathrm{~h}$ and at RT for another $24 \mathrm{~h}$. The reaction mixture was opened to air and allowed to stir for $12 \mathrm{~h}$. The reaction mixture was filtered through Celite, concentrated in vacuo and the product was purified by silica gel column chromatography using 5\% EtOAc in hexanes to give naphthopyran 38c $(22.4 \mathrm{mg})$ in $98 \%$ yield as colorless liquid. Spectral data for 38c: ${ }^{1} \mathrm{H}$ NMR $\left(500 \mathrm{MHz}, \mathrm{CDCl}_{3}\right) \delta 0.25(\mathrm{~s}, 9 \mathrm{H}), 0.97(\mathrm{t}, 3 \mathrm{H}, J=7.17 \mathrm{~Hz}), 1.44(\mathrm{~s}, 6 \mathrm{H}), 1.59-1.74(\mathrm{~m}, 2 \mathrm{H}), 2.68-2.78(\mathrm{~m}, 2 \mathrm{H}), 3.88(\mathrm{~s}$, 3H), $5.55(\mathrm{~d}, 1 \mathrm{H}, J=10.1 \mathrm{~Hz}), 6.63(\mathrm{~s}, 1 \mathrm{H}), 6.98(\mathrm{dd}, 1 \mathrm{H}, J=9.1,0.6 \mathrm{~Hz}), 7.71(\mathrm{dd}, 1 \mathrm{H}, J=10.3,0.6 \mathrm{~Hz}), 7.80(\mathrm{~d}, 1 \mathrm{H}, J=9.1$ $\mathrm{Hz}) ;{ }^{13} \mathrm{C} \mathrm{NMR}\left(75 \mathrm{MHz}, \mathrm{CDCl}_{3}\right) \delta 0.91,14.20,23.48,27.33,32.91,55.85,74.59,109.45,114.45,118.09,121.55,123.39$, $124.25,124.38,125.57,127.04,142.81,151.22,141.32$; IR (neat) 2961, 2930, 2870, 1591, 1454, 1307 $\mathrm{cm}^{-1}$; mass spectrum (EI) $m / z$ (\% rel. int.) $371 \mathrm{M}^{+}+1$ (24), $370 \mathrm{M}^{+}$(82), 358 (11), 356 (100), 355 (19). Anal calcd for $\mathrm{C}_{22} \mathrm{H}_{30} \mathrm{O}_{3} \mathrm{Si}: \mathrm{C}, 71.31$; $\mathrm{H}, 8.16$. Found: C, 71.75; H, 8.43. 


\section{Synthesis of the TBS-Protected Naphthopyran 38b from Carbene Complex 20 and 1-Pentyne.}

To a flame-dried $25 \mathrm{~mL}$ flask with the 14/20 joint replaced by a high-vacuum threaded Teflon stopcock was added chromene carbene complex 20 (100 mg, $0.254 \mathrm{mmol})$, benzene (5.0 mL), 1-pentyne (56 $\mu \mathrm{L}, 0.508 \mathrm{mmol}), \mathrm{TBSCl}(115 \mathrm{mg}$, $0.762 \mathrm{mmol})$ and $\mathrm{N}, \mathrm{N}$-diisopropylethylamine $(55 \mu \mathrm{L}, 1.270 \mathrm{mmol})$ were then added to the reaction mixture. The system was deoxygenated by the freeze-pump-thaw method (-196 to $25^{\circ} \mathrm{C}, 3$ cycles). The flask was back-filled with argon at $25^{\circ} \mathrm{C}$ and sealed. The reaction mixture was then stirred at $50{ }^{\circ} \mathrm{C}$ for $24 \mathrm{~h}$ and then at RT for another $24 \mathrm{~h}$. The reaction mixture was opened to air and allowed to stir for $12 \mathrm{~h}$. The reaction mixture was filtered through Celite, concentrated in vacuo and the product was purified by silica gel column chromatography using $25 \%$ benzene in hexane to give $\mathbf{3 8 b}$ in $78 \%$ yield along with a $10 \%$ yield of slightly impure quinone 39. Spectral data for 38b: ${ }^{1} \mathrm{H}$ NMR $\left(500 \mathrm{MHz}, \mathrm{CDCl}_{3}\right) \delta 0.11(\mathrm{~s}, 6 \mathrm{H}), 0.93(\mathrm{t}, 3 \mathrm{H}, J=$ $7.2 \mathrm{~Hz}), 1.07$ (s, 9H), 1.43 (s, 6H), 1.52-1.70 (m, 2H), 2.63 (t, 2H, J = 7.7 Hz), 3.87 (s, 3H), 5.53 (d, 1H, J = 10.2 Hz), 6. 63 (s, $1 \mathrm{H}), 6.95(\mathrm{~d}, 1 \mathrm{H}, J=9.1 \mathrm{~Hz}), 7.70(\mathrm{~d}, 1 \mathrm{H}, J=10.2 \mathrm{~Hz}), 7.83(\mathrm{~d}, 1 \mathrm{H}, J=9.1 \mathrm{~Hz}) ;{ }^{13} \mathrm{C} \mathrm{NMR}\left(75 \mathrm{MHz}, \mathrm{CDCl}_{3}\right) \delta-3.29,14.02$, $18.64,23.61,26.12,27.26,32.61,55.84,74.53,109.55,114.27,117.61,121.56,123.39,124.49,124.72,125.39,126.91$, 142.32, 151.16, 151.24; IR (neat) 2959, 2930, 2858, 1591, 1454, $1337 \mathrm{~cm}^{-1}$; mass spectrum (EI) $\mathrm{m} / \mathrm{z}$ (\% rel. int.) $413 \mathrm{M}^{+}+1$ (95), $412 \mathrm{M}^{+}$(15), 400 (22), 399 (79), 398 (100), 383 (6). Anal calcd for $\mathrm{C}_{25} \mathrm{H}_{36} \mathrm{O}_{3} \mathrm{Si}: \mathrm{C}, 72.77 ; \mathrm{H}, 8.79$. Found: C, 72.60; $\mathrm{H}$, 8.40 .

\section{Synthesis of the Triflated Naphthopyran 38f from Carbene Complex 20 and 1-Pentyne.}

To a flame-dried $25 \mathrm{~mL}$ flask with the 14/20 joint replaced by a high-vacuum threaded Teflon stopcock was added chromene carbene complex 20 (75 mg, $0.189 \mathrm{mmol})$ in benzene $(3.8 \mathrm{~mL})$ and 1-pentyne $(47 \mu \mathrm{L}, 0.473 \mathrm{mmol})$. The system was deoxygenated by the freeze-pump-thaw method $\left(-196\right.$ to $25^{\circ} \mathrm{C}, 3$ cycles). The flask was back-filled with argon at $25^{\circ} \mathrm{C}$, sealed and the mixture was then stirred at $55{ }^{\circ} \mathrm{C}$ for $24 \mathrm{~h}$. The reaction mixture was cooled to $0{ }^{\circ} \mathrm{C}$ and was treated with trifloromethane sulfonic anhydride $(48 \mu \mathrm{L}, 0.283 \mathrm{mmol})$ and $\mathrm{N}, \mathrm{N}$-diisopropylethylamine $(66 \mu \mathrm{L}, 0.378 \mathrm{mmol})$. The system was deoxygenated by the freeze-pump-thaw method ( -196 to $25{ }^{\circ} \mathrm{C}, 3$ cycles) and back-filled with argon at $25{ }^{\circ} \mathrm{C}$. The reaction mixture was stirred at $25{ }^{\circ} \mathrm{C}$ for $24 \mathrm{~h}$. The reaction mixture was opened to air and allowed to stir for $12 \mathrm{~h}$. The reaction mixture was then filtered through Celite, concentrated in vacuo and the product was purified by silica gel column chromatography using 5\% EtOAc in hexane to give naphthopyran $\mathbf{3 8 f}(56 \mathrm{mg})$ in $69 \%$ yield as off-white solid. Spectral data of 38f: $\mathrm{mp}=90-92{ }^{\circ} \mathrm{C} ;{ }^{1} \mathrm{H} \operatorname{NMR}\left(500 \mathrm{MHz}, \mathrm{CDCl}_{3}\right) \delta 0.98(\mathrm{t}, 3 \mathrm{H}, J=7.3 \mathrm{~Hz}), 1.45(\mathrm{~s}, 6 \mathrm{H}), 1.62-1.76(\mathrm{~m}, 2 \mathrm{H}), 2.74-2.82(\mathrm{~m}$, 2H), $3.94(\mathrm{~s}, 3 \mathrm{H}), 5.59(\mathrm{~d}, 1 \mathrm{H}, J=10.3 \mathrm{~Hz}), 6.64(\mathrm{~s}, 1 \mathrm{H}), 7.14(\mathrm{~d}, 1 \mathrm{H}, J=9.3 \mathrm{~Hz}), 7.64(\mathrm{~d}, 1 \mathrm{H}, J=9.8 \mathrm{~Hz}), 7.80(\mathrm{~d}, 1 \mathrm{H}, J=9.3$ $\mathrm{Hz}) ;{ }^{13} \mathrm{C}$ NMR $\left(75 \mathrm{MHz}, \mathrm{CDCl}_{3}\right) \delta 13.89,23.32,27.24,32.52,55.64,74.90,107.37,115.02,118.87$ (q, J = $\left.318 \mathrm{~Hz}\right), 120.46$, 121.91, 122.33, 122.66, 124.36, 128.14, 130.12, 136.37, 152.07, 156.27; IR (neat) 2970, 2936, 2876m 1628m $1456 \mathrm{~cm}^{-1}$; mass spectrum (FAB) m/z (\% rel. int.) $430 \mathrm{M}^{+}$(98), 415 (20), 297 (100), 281 (15), 267 (15); HRMS (FAB) calcd for $m / z$ $\mathrm{C}_{20} \mathrm{H}_{21} \mathrm{~F}_{3} \mathrm{O}_{5} \mathrm{~S} 430.1062$, measd 430.1064. Anal calcd for $\mathrm{C}_{20} \mathrm{H}_{21} \mathrm{~F}_{3} \mathrm{O}_{5} \mathrm{~S}: \mathrm{C}, 55.81 ; \mathrm{H}, 4.92$. Found: C, 56.07, H, 5.06. 


\section{Synthesis of Naphthopyran 43 via Suzuki Coupling with Naphthopyran $38 f$.}

To a flame-dried $25 \mathrm{~mL}$ flask with the 14/20 joint replaced by a high-vacuum threaded Teflon stopcock was added $\mathrm{Pd}\left(\mathrm{PPh}_{3}\right)_{4}(20 \mathrm{mg}, 0.017 \mathrm{mmol})$, phenyl boronic acid $(17 \mathrm{mg}, 0.14 \mathrm{mmol}), \mathrm{K}_{3} \mathrm{PO}_{4}(30 \mathrm{mg}, 0.14 \mathrm{mmol})$ and naphthopyran triflate $\mathbf{3 8 f}$ ( $31 \mathrm{mg}, 0.07 \mathrm{mmol})$ in 1,4 dioxane $(4 \mathrm{~mL})$. The system was deoxygenated by the freeze-pump-thaw method $(-196$ to $25^{\circ} \mathrm{C}, 3$ cycles). The flask was back-filled with argon at RT, sealed and the reaction mixture was stirred at $80{ }^{\circ} \mathrm{C}$ for 3 days. The reaction mixture was then filtered through Celite, concentrated in vacuo and the product was purified by silica gel column chromatography using 5\% EtOAc in hexane to give coupling product $\mathbf{4 3}(17.4 \mathrm{mg})$ in $69 \%$ yield as an off-white solid. Spectral data of 43: $\mathrm{mp}=107-108{ }^{\circ} \mathrm{C} ;{ }^{1} \mathrm{H}$ NMR $\left(500 \mathrm{MHz}, \mathrm{CDCl}_{3}\right) \delta 0.80(\mathrm{t}, 3 \mathrm{H}, J=7.3 \mathrm{~Hz}), 1.44(\mathrm{~s}, 6 \mathrm{H}), 1.46-1.58(\mathrm{~m}, 2 \mathrm{H}), 2.34-$ $2.42(\mathrm{~m}, 2 \mathrm{H}), 3.98(\mathrm{~s}, 3 \mathrm{H}), 5.57(\mathrm{~d}, 1 \mathrm{H}, J=10.2 \mathrm{~Hz}), 6.78(\mathrm{~s}, 1 \mathrm{H}), 6.86(\mathrm{~d}, 1 \mathrm{H}, J=9.3 \mathrm{~Hz}), 7.10(\mathrm{~d}, 1 \mathrm{H}, J=9.3 \mathrm{~Hz}), 7.10$ (d, $1 \mathrm{H}, J=9.3 \mathrm{~Hz}), 7.18-7.22(\mathrm{~m}, 2 \mathrm{H}), 7.36-7.40(\mathrm{~m}, 1 \mathrm{H}), 7.40-7.46(\mathrm{~m}, 2 \mathrm{H}), 7.76(\mathrm{~d}, 1 \mathrm{H}, J=10.3 \mathrm{~Hz}) ;{ }^{13} \mathrm{C} \mathrm{NMR}(75 \mathrm{MHz}$, $\left.\mathrm{CDCl}_{3}\right) \delta 14.14,24.64,27.15,35.87,55.46,74.46,108.25,114.41,118.51,120.52,123.68,126.73,127.06,128.10,128.19$, 130.83, 130.88, 131.46, 135.42, 140.08, 150.88, 156.05; IR (neat) 2959, 2928, 2870, 1630; mass spectrum (FAB) $\mathrm{m} / z$ (\% rel. int.) $359 \mathrm{M}^{+}+1(60), 358 \mathrm{M}^{+}$(100), 343 (60); HRMS (FAB) calcd for $m / z \mathrm{C}_{25} \mathrm{H}_{26} \mathrm{O}_{2}$ 358.1933, measd 358.1935. Anal calcd for $\mathrm{C}_{25} \mathrm{H}_{26} \mathrm{O}_{2} ; \mathrm{C}, 83.76 ; \mathrm{H}, 7.31$. Found: C, 83.89; H, 7.39.

\section{Synthesis of the TMS-Protected Naphthopyran 41c from Carbene Complex 20 and 3-Hexyne.}

To a flame-dried $10 \mathrm{~mL}$ flask with the 14/20 joint replaced by a high-vacuum threaded Teflon stopcock was added chromene carbene complex 20 (18 mg, $0.045 \mathrm{mmol})$, benzene (1.9 mL), 3-hexyne (11 $\mu \mathrm{L}, 0.090 \mathrm{mmol})$, TMSCl (12 $\mu \mathrm{L}, 0.135$ mmol) and N,N-diisopropylethylamine ( $39 \mu \mathrm{L}, 0.742 \mathrm{mmol})$. The system was deoxygenated by the freeze-pump-thaw method ( -196 to $25^{\circ} \mathrm{C}, 3$ cycles). The flask was back-filled with argon at RT and sealed. The reaction mixture was then stirred at 50

${ }^{\circ} \mathrm{C}$ for $24 \mathrm{~h}$ and then at RT for another $24 \mathrm{~h}$. The reaction mixture was opened to air and allowed to stir for $12 \mathrm{~h}$, filtered through Celite and concentrated in vacuo. The reaction mixture was diluted with in $10 \mathrm{~mL}$ of pentane and kept at $0{ }^{\circ} \mathrm{C}$ for $5 \mathrm{~h}$. After $5 \mathrm{~h}$, the pentane solution was filtered through Celite and concentrated in vacuo to give $16.5 \mathrm{mg}$ (95\%) of essentially pure naphthopyran 41c as a light yellow oil. Spectral data for 41c: ${ }^{1} \mathrm{H}$ NMR $\left(500 \mathrm{MHz}, \mathrm{CDCl}_{3}\right) \delta 0.26(\mathrm{~s}, 9 \mathrm{H}), 1.14(\mathrm{t}, 3 \mathrm{H}, J=7.8$ $\mathrm{Hz}), 1.22$ (t, 3H, $J=7.3 \mathrm{~Hz}), 1.46$ (s, 6H), 2.71 (q, 2H, $J=7.6 \mathrm{~Hz}), 2.79$ (q, 2H, $J=7.5 \mathrm{~Hz}), 3.63$ (s, 3H), 5.59 (d, $1 \mathrm{H}, J=9.8$ $\mathrm{Hz}), 6.93(\mathrm{~d}, 1 \mathrm{H}, J=8.8 \mathrm{~Hz}), 7.59(\mathrm{~d}, 1 \mathrm{H}, J=9.8 \mathrm{~Hz}), 7.80(\mathrm{~d}, 1 \mathrm{H}, J=9.3 \mathrm{~Hz}) ;{ }^{13} \mathrm{C} \mathrm{NMR}\left(125 \mathrm{MHz}, \mathrm{CDCl}_{3}\right) \delta 0.94,14.64$, $16.00,20.23,20.61,27.09,61.38,74.64,113.03,117.01,123.00,123.43,123.99,124.68,126.80,126.96,134.83,145.80$, 148.70, 151.40; IR (neat) 2970, 2936, 2882, $1639 \mathrm{~cm}^{-1}$; mass spectrum (FAB) $\mathrm{m} / z$ (\% rel. int.) $385 \mathrm{M}^{+}+1(40), 384 \mathrm{M}^{+}(100)$, 369 (40), 283 (5); HRMS (FAB) calcd for $m / z \mathrm{C}_{23} \mathrm{H}_{32} \mathrm{O}_{3} \mathrm{Si} 384.2120$, measd $385.2124\left(\mathrm{M}^{+}+1\right)$. 


\section{Synthesis of the TBS-Protected Naphthopyran 41b from Carbene Complex 20 and 3-Hexyne.}

To a flame-dried $25 \mathrm{~mL}$ flask with the 14/20 joint replaced by a high-vacuum threaded Teflon stopcock was added chromene carbene complex 20 (100 mg, $0.254 \mathrm{mmol})$, benzene $(5.0 \mathrm{~mL}), 3$-hexyne (58 $\mu \mathrm{L}, 0.508 \mathrm{mmol}), \mathrm{TBSCl}(115 \mathrm{mg}$, $0.762 \mathrm{mmol}$ ) and $\mathrm{N}, \mathrm{N}$-diisopropylethylamine $(55 \mu \mathrm{L}, 1.270 \mathrm{mmol})$. The system was deoxygenated by the freeze-pump-thaw method ( -196 to $25^{\circ} \mathrm{C}, 3$ cycles). The flask was back-filled with argon at RT and sealed. The reaction mixture was then stirred at $50{ }^{\circ} \mathrm{C}$ for $24 \mathrm{~h}$ and then at RT for another $24 \mathrm{~h}$. The reaction mixture was opened to air and stirred for $12 \mathrm{~h}$. The reaction mixture was filtered through Celite, concentrated in vacuo and the product was purified by silica gel column chromatography using $25 \%$ benzene in hexane to give naphthopyran $41 \mathbf{b}(92 \mathrm{mg})$ in $85 \%$ yield as a white solid. Spectral data for 41b: $\mathrm{mp}=104-106{ }^{\circ} \mathrm{C} ;{ }^{1} \mathrm{H} \mathrm{NMR}\left(500 \mathrm{MHz}, \mathrm{CDCl}_{3}\right) \delta 0.14(\mathrm{~s}, 6 \mathrm{H}), 1.07(\mathrm{~s}, 9 \mathrm{H}), 1.09(\mathrm{t}, 3 \mathrm{H}, J=7.5 \mathrm{~Hz}), 1.22(\mathrm{t}, 3 \mathrm{H}, J=$ $7.4 \mathrm{~Hz}), 1.46$ (s, 6H), 2.60-2.90 (m, 4H), 3.63 (s, 3H), 5.59 (d, 1H, $J=10.0 \mathrm{~Hz}), 6.90$ (d, 1H, $J=9.1 \mathrm{~Hz}), 7.59$ (d, $1 \mathrm{H}, J=10.0$ $\mathrm{Hz}), 7.83(\mathrm{~d}, 1 \mathrm{H}, J=9.1 \mathrm{~Hz}) ;{ }^{13} \mathrm{C}$ NMR $\left(75 \mathrm{MHz}, \mathrm{CDCl}_{3}\right) \delta-3.09,14.91,16.04,18.70,20.17,20.33,26.10,27.06,61.37$, 74.63, 112.89, 116.58, 123.06, 123.50, 123.84, 125.24, 126.86, 127.04, 134.94, 145.27, 148.70, 151.41; IR (neat) 2969, 2982, 2869, 1449, 1377, $1257 \mathrm{~cm}^{-1}$; mass spectrum (EI) m/z (\% rel. int.) $427 \mathrm{M}^{+}+1$ (75), $426 \mathrm{M}^{+}$(8), 413 (54), 412 (100), 411 (10); Anal calcd for $\mathrm{C}_{26} \mathrm{H}_{38} \mathrm{O}_{3} \mathrm{Si}$ : C,73.19; H, 8.98. Found: C, 73.45; H, 9.21.

\section{Synthesis of the TMS-Protected Naphthopyran 42c from Carbene Complex 20 and Trimethylsilylacetyelene.}

To a flame-dried $10 \mathrm{~mL}$ flask with the 14/20 joint replaced by a high-vacuum threaded Teflon stopcock was added chromene carbene complex $20(25 \mathrm{mg}, 0.063 \mathrm{mmol})$, benzene $(1.2 \mathrm{~mL})$, trimethylsilylacetylene ( $25 \mu \mathrm{L}, 0.126 \mathrm{mmol}), \mathrm{TMSCl}$ $(24 \mu \mathrm{L}, 0.189 \mathrm{mmol})$ and $\mathrm{N}, \mathrm{N}$-diisopropylethylamine $(55 \mu \mathrm{L}, 0.315 \mathrm{mmol})$ were then added to the reaction mixture. The system was deoxygenated by the freeze-pump-thaw method (-196 to $25^{\circ} \mathrm{C}, 3$ cycles). The flask was back-filled with argon at RT and sealed. The reaction mixture was stirred at $50{ }^{\circ} \mathrm{C}$ for $24 \mathrm{~h}$ and then at RT for another $24 \mathrm{~h}$. The reaction mixture was opened to air and stirred for $12 \mathrm{~h}$, filtered through Celite and concentrated in vacuo. The product was purified by silica gel column chromatography using 2\% EtOAc in hexanes to give naphthopyran 42c $(22.5 \mathrm{mg}$ ) in $89 \%$ yield as a white solid. Spectral data for 42c: $\mathrm{mp}=79-81{ }^{\circ} \mathrm{C} ;{ }^{1} \mathrm{H}$ NMR $\left(300 \mathrm{MHz}, \mathrm{CDCl}_{3}\right) \delta 0.25(\mathrm{~s}, 9 \mathrm{H}), 0.34(\mathrm{~s}, 9 \mathrm{H}), 1.44(\mathrm{~s}, 6 \mathrm{H}), 3.88(\mathrm{~s}, 3 \mathrm{H}), 5.54$ $(\mathrm{d}, 1 \mathrm{H}, J=10.1 \mathrm{~Hz}), 6.77(\mathrm{~s}, 1 \mathrm{H}), 6.96(\mathrm{dd}, 1 \mathrm{H}, J=9.2,0.9 \mathrm{~Hz}), 7.71(\mathrm{dd}, 1 \mathrm{H}, J=10.1,0.7 \mathrm{~Hz}), 7.85(\mathrm{~d}, 1 \mathrm{H}, J=9.2 \mathrm{~Hz}) ;{ }^{13} \mathrm{C}$ NMR $\left(75 \mathrm{MHz}, \mathrm{CDCl}_{3}\right) \delta$ 0.26, 1.62, 27.32, 55.92, 74.77, 112.41, 114.41, 117.63, 120.26, 123.30, 123.98, 124.96, 125.07, 126.89, 150.96, 151.58, 152.11; IR (neat) 2955, 2926, 2855, 1448, $1389 \mathrm{~cm}^{-1}$; mass spectrum (EI) $\mathrm{m} / z$ (\% rel. int.) $400 \mathrm{M}^{+}$ (24), 387(12), 386 (100), 371 (6), 297 (5). Anal calcd for $\mathrm{C}_{22} \mathrm{H}_{32} \mathrm{O}_{3} \mathrm{Si}_{2}: \mathrm{C}, 65.95 ; \mathrm{H}, 8.05$. Found: C, 66.06; H, 8.40.

\section{Synthesis of the MOM-Protected Naphthopyran 42e from Carbene Complex 20 and Trimethylsilylacetyelene.}

To a flame-dried $10 \mathrm{~mL}$ flask with the 14/20 joint replaced by a high-vacuum threaded Teflon stopcock was added chromene carbene complex $20(100 \mathrm{mg}, 0.254 \mathrm{mmol})$ and benzene $(5 \mathrm{~mL})$. The trimethylsilyl acetylene $(72 \mu \mathrm{L}, 0.508 \mathrm{mmol})$, $\mathrm{MOMCl}(58 \mu \mathrm{L}, 0.762 \mathrm{mmol})$ and $\mathrm{N}, \mathrm{N}$-diisopropylethylamine $(221 \mu \mathrm{L}, 1.270 \mathrm{mmol})$ were then added to the reaction mixture. 
The system was deoxygenated by the freeze-pump-thaw method ( -196 to $25{ }^{\circ} \mathrm{C}, 3$ cycles). The flask was back-filled with argon at RT and sealed. The reaction mixture was stirred at $50{ }^{\circ} \mathrm{C}$ for $24 \mathrm{~h}$ and then at RT for another $24 \mathrm{~h}$. The reaction mixture was opened to air stirred for $12 \mathrm{~h}$, filtered through Celite and concentrated in vacuo. The product was purified by silica gel column chromatography with $5 \%$ benzene in hexane to give naphthopyran $42 \mathrm{e}(81 \mathrm{mg})$ in $85 \%$ yield as a white solid. Spectral data for 42e: $\mathrm{mp}=86-88{ }^{\circ} \mathrm{C} ;{ }^{1} \mathrm{H}$ NMR $\left(500 \mathrm{MHz}, \mathrm{CDCl}_{3}\right) \delta 0.35(\mathrm{~s}, 9 \mathrm{H}), 1.44(\mathrm{~s}, 6 \mathrm{H}), 3.63(\mathrm{~s}, 3 \mathrm{H}), 3.90(\mathrm{~s}, 3 \mathrm{H}), 5.02$ (s, 2H), $5.55(\mathrm{~d}, 1 \mathrm{H}, J=9.8 \mathrm{~Hz}), 6.78(\mathrm{~s}, 1 \mathrm{H}), 7.05(\mathrm{dd}, 1 \mathrm{H}, J=8.8,1.0 \mathrm{~Hz}), 7.70(\mathrm{~d}, 1 \mathrm{H}, J=10.2 \mathrm{~Hz}), 8.0(\mathrm{~d}, 1 \mathrm{H}, J=9.3 \mathrm{~Hz})$;

${ }^{13} \mathrm{C}$ NMR $\left(75 \mathrm{MHz}, \mathrm{CDCl}_{3}\right) \delta$ 0.01, 27.25, 55.74, 57.71, 74.79, 101.00, 111.28, 114.28, 118.91, 123.20, 124.12, 124.31, 125.54, 125.40, 127.09, 152.32, 153.04, 153.31; IR (neat) 2953, 2895, 2840, 1603, $1450 \mathrm{~cm}^{-1}$; mass spectrum (EI) $\mathrm{m} / z$ (\% rel. int.) $373 \mathrm{M}^{+}+1$ (100), $372 \mathrm{M}^{+}(80), 358$ (66), 357 (18), 328 (16), 298 (23), 297 (22), 296 (23). Anal calcd for $\mathrm{C}_{21} \mathrm{H}_{28} \mathrm{O}_{4} \mathrm{Si}: \mathrm{C}$, 67.71; H, 7.58. Found: C, 68.08; H, 7.96.

\section{Deprotection of the TMS-Protected Naphthopyran 38c - Isolation of the Hydroxynaphthopyran 38a.}

To a stirred solution of $38 \mathrm{c}(31 \mathrm{mg}, 0.083 \mathrm{mmol})$ in $5 \mathrm{~mL}$ THF at $0{ }^{\circ} \mathrm{C}$ was added TBAF $(166 \mu \mathrm{L}, 0.166 \mathrm{mmol}, 1.0 \mathrm{M}$ solution in THF) dropwise. The reaction mixture was stirred for $30 \mathrm{~min}$ and, quenched with $5 \mathrm{~mL}$ water and extracted with EtOAc $(2 \times 10 \mathrm{~mL})$. The organic layer was concentrated in vacuo and the product was purified by silica gel column chromatography with 5\% EtOAc in hexane to give slightly impure phenol 38a in 75\% yield (18.5 mg) as a colorless oil. This compound contained slight amounts of impurities and its purity could not be enhanced by additional chromatography. This compound was fully characterized upon conversion to quinone 39 (vide infra). Spectral data for 38a: ${ }^{1} \mathrm{H} \mathrm{NMR}(500 \mathrm{MHz}$, $\left.\mathrm{CDCl}_{3}\right) \delta 0.99(\mathrm{t}, 3 \mathrm{H}, J=7.3 \mathrm{~Hz}), 1.44(\mathrm{~s}, 6 \mathrm{H}), 1.60-1.78(\mathrm{~m}, 2 \mathrm{H}), 2.63(\mathrm{t}, 2 \mathrm{H}, J=7.7 \mathrm{~Hz}), 3.87(\mathrm{~s}, 3 \mathrm{H}), 4.63(\mathrm{~s}, 1 \mathrm{H}), 5.56(\mathrm{~d}$, $1 \mathrm{H}, J=10.1 \mathrm{~Hz}), 6.60(\mathrm{~s}, 1 \mathrm{H}), 7.03(\mathrm{dd}, 1 \mathrm{H}, J=9.1,0.6 \mathrm{~Hz}), 7.71(\mathrm{dd}, 1 \mathrm{H}, J=10.5,0.6 \mathrm{~Hz}), 7.95(\mathrm{~d}, 1 \mathrm{H}, J=9.1 \mathrm{~Hz}) ;{ }^{13} \mathrm{C}$ $\operatorname{NMR}\left(75 \mathrm{MHz}, \mathrm{CDCl}_{3}\right) \delta 14.03,23.34,27.20,32.09,56.15,74.62,109.75,114.52,118.39,118.45,121.58,122.16,122.83$, 123.26, 127.28, 142.52, 150.84, $1 \mathrm{sp}^{2} \mathrm{C}$ not located; IR (neat) 3455, 2961, 2930, 2870, 1626, $1454 \mathrm{~cm}^{-1}$; mass spectrum (EI) $m / z$ (\% rel. int.) $298 \mathrm{M}^{+}$(29), 284 (21), 283 (100), 268 (21), 239 (10).

\section{Oxidation of the Hydroxynaphthopyhran 38a to Naphthoquinonepyran 39.}

To a stirred solution of $\mathbf{3 8 a}(9.0 \mathrm{mg}, 0.030 \mathrm{mmol})$ in $2 \mathrm{~mL}$ THF at $0{ }^{\circ} \mathrm{C}$ was added CAN (41 $\left.\mathrm{mg}, 0.075 \mathrm{mmol}\right)$ in 0.2 $\mathrm{mL}$ water. The reaction mixture was stirred for $30 \mathrm{~min}$ at $0{ }^{\circ} \mathrm{C}$ and then quenched with water. The water layer was then extracted with $2 \times 10 \mathrm{~mL}$ EtOAc. The combined organic layer was washed with $5 \mathrm{~mL}$ of water, dried over $\mathrm{MgSO}_{4}$ and concentrated in vacuo. The crude product was purified by silica gel column chromatography with $5 \%$ EtOAc in hexane to give a $65 \%$ yield of quinone 39 as a yellow oil. Spectral data for 39: ${ }^{1} \mathrm{H} \mathrm{NMR}\left(500 \mathrm{MHz}, \mathrm{CDCl}_{3}\right) \delta 0.97(\mathrm{t}, 3 \mathrm{H}, J=7.3 \mathrm{~Hz}), 1.45$ (s, 6H), 1.50-62 (m, 2H), 2.42-2.52 (m, 2H), 5.89 (d, 1H, $J=10.2 \mathrm{~Hz}), 6.63(\mathrm{t}, 1 \mathrm{H}, J=1.3 \mathrm{~Hz}), 7.03(\mathrm{dd}, 1 \mathrm{H}, J=8.5,0.8 \mathrm{~Hz})$, $7.74(\mathrm{dd}, 1 \mathrm{H}, J=10.4,0.7 \mathrm{~Hz}), 7.94(\mathrm{~d}, 1 \mathrm{H}, J=8.5 \mathrm{~Hz}) ;{ }^{13} \mathrm{C} \mathrm{NMR}\left(75 \mathrm{MHz}, \mathrm{CDCl}_{3}\right) \delta 13.85,21.17,27.99,31.05,76.88$, $119.88,120.47,121.08,126.57,126.81,128.90,134.69,136.12,150.11,158.58,184.50,188.06$; IR (neat) 2964, 2930, 2874 , 
1657, $1298 \mathrm{~cm}^{-1}$; mass spectrum (EI) $\mathrm{m} / z$ (\% rel. int.) $282 \mathrm{M}^{+}, 268$ (21), 267 (100), 239 (4), 238 (4), 210 (4). Anal calcd for $\mathrm{C}_{18} \mathrm{H}_{18} \mathrm{O}_{3}: \mathrm{C}, 76.57 ; \mathrm{H}, 6.43$. Found: $\mathrm{C}, 76.42 ; \mathrm{H}, 6.01$.

Deprotection of the TMS-Protected Naphthopyran 36c - Isolation of the Hydroxynaphthopyran 36a.

To a stirred solution of $\mathbf{3 6 c}(20 \mathrm{mg}, 0.049 \mathrm{mmol})$ in $5 \mathrm{~mL}$ THF at $0{ }^{\circ} \mathrm{C}$ was added TBAF $(73 \mu \mathrm{L}, 0.073 \mathrm{mmol}, 1.0 \mathrm{M}$ solution in THF) dropwise. The reaction mixture was stirred for $30 \mathrm{~min}$ and then quenched with $2 \mathrm{~mL}$ water. The reaction mixture was extracted with EtOAc $(2 \times 10 \mathrm{~mL})$, dried over $\mathrm{MgSO}_{4}$ and then the organic layer was concentrated in vacuo and purified by silica gel column chromatography using 5\% EtOAc in hexane to give compound $36 \mathrm{a}$ in $65 \%$ yield as a colorless oil. The ${ }^{1} \mathrm{H}$ NMR spectrum revealed that the phenol 36a was not completely pure. The compound was not stable long enough to provide a good ${ }^{13} \mathrm{C}$ NMR spectrum. This compound was characterized by conversion to the quinone $\mathbf{3 7}$ (vide infra). Spectral data for 36a: ${ }^{1} \mathrm{H}$ NMR (500 MHz, $\left.\mathrm{CDCl}_{3}\right) \delta 1.46(\mathrm{~s}, 6 \mathrm{H}), 3.89$ (s, 3H), 5.40 (s, 1H), 5.59 (d, 1H, J=10.1 Hz), 6.73 (s, 1H), $7.08(\mathrm{~d}, 1 \mathrm{H}, J=8.8 \mathrm{~Hz}), 7.36-7.44(\mathrm{~m}, 1 \mathrm{H})$ 7.48-7.54 (m, 4H), 7.75 (d, 1H, $J=10 \mathrm{~Hz}), 8.10(\mathrm{~d}, 1 \mathrm{H}, J=9.1 \mathrm{~Hz})$; IR (neat) 3555, 2970, 2926, 2851.1626, 1591, $1454 \mathrm{~cm}^{-1}$; mass spectrum (EI) $\mathrm{m} / z$ (\% rel. int.) $332 \mathrm{M}^{+}$(39), 318 (26), 317 (15), 303 (27).

\section{Oxidation of the Hydroxynaphthopyhran 36a to Naphthoquinonepyran 37.}

To a stirred solution of $36 \mathrm{a}(10.5 \mathrm{mg}, 0.031 \mathrm{mmol})$ in $2 \mathrm{~mL}$ THF at $0{ }^{\circ} \mathrm{C}$ was added CAN (43 mg, $\left.0.077 \mathrm{mmol}\right)$ in 0.5 $\mathrm{mL}$ water. The reaction mixture was stirred for $30 \mathrm{~min}$ at $0{ }^{\circ} \mathrm{C}$ and then quenched with water. The water layer was then extracted with $2 \times 10 \mathrm{~mL}$ EtOAc. The combined organic layer was washed with $5 \mathrm{~mL}$ of water, dried over $\mathrm{MgSO}_{4}$ and concentrated in vacuo. The product was purified by silica gel column chromatography with $5 \%$ EtOAc in hexane to give a $65 \%$ yield of quinone 37 as an orange solid. Spectral data for 37: $\mathrm{mp}=156-158{ }^{\circ} \mathrm{C} ;{ }^{1} \mathrm{H} \mathrm{NMR}\left(500 \mathrm{MHz}, \mathrm{CDCl}_{3}\right) \delta 1.47(\mathrm{~s}$, $6 \mathrm{H}), 5.93(\mathrm{~d}, 1 \mathrm{H}, J=10.2 \mathrm{~Hz}), 6.94(\mathrm{~s}, 1 \mathrm{H}), 7.09(\mathrm{dd}, 1 \mathrm{H}, J=8.8,1.0 \mathrm{~Hz}), 7.68-7.90(\mathrm{~m}, 3 \mathrm{H}), 7.50-7.52(\mathrm{~m}, 2 \mathrm{H}), 7.78(\mathrm{~d}, 1 \mathrm{H}$, $J=10.1 \mathrm{~Hz}), 8.03(\mathrm{~d}, 1 \mathrm{H}, J=8.8 \mathrm{~Hz}) ;{ }^{13} \mathrm{C} \mathrm{NMR}\left(75 \mathrm{MHz}, \mathrm{CDCl}_{3}\right) \delta 28.02,77.03,119.84,120.43,121.39,126.93,128.29$, $129.38,129.39,129.82,133.30,134.95,136.48,146.64,158.74,183.60,187.95$, one $\mathrm{sp}^{2} \mathrm{C}$ not located; IR (neat) 3061, 2978, $2930,1655 \mathrm{~cm}^{-1}$; mass spectrum (EI) $\mathrm{m} / z$ (\% rel. int.) $316 \mathrm{M}^{+}$(2), 302 (26), 301 (100), 273 (2); HRMS (FAB) calcd for $m / z$ $\mathrm{C}_{21} \mathrm{H}_{16} \mathrm{O}_{3} 316.3499$, measd 317.1177 $\left(\mathrm{M}^{+}+1\right)$.

\section{The Reaction of the Carbene Complex 20 with Triyne 44 - Isolation of the Olefin Insertion Product 47a.}

To a flame-dried $10 \mathrm{~mL}$ flask with the 14/20 joint replaced by a high-vacuum threaded Teflon stopcock was added chromene carbene complex 20 (50 mg, $0.127 \mathrm{mmol})$, bis-TIPS triyne 44 (49 mg, 0.127) and dichloromethane (2.5 mL). The system was deoxygenated by the freeze-pump-thaw method (-196 to $25^{\circ} \mathrm{C}, 3$ cycles). The flask was back-filled with argon at RT and sealed. The mixture was then stirred at $90{ }^{\circ} \mathrm{C}$ for $24 \mathrm{~h}$. The reaction was opened to air and allowed to stir for $12 \mathrm{~h}$. The reaction mixture was filtered through Celite and concentrated in vacuo. The product was purified by silica gel column chromatography using a 2:98) mixture of EtOAc/hexane to give the olefin-addition product $47 \mathbf{a}(66 \mathrm{mg})$ in $88 \%$ yield as a 
brown oil. Spectral data for 47a: ${ }^{1} \mathrm{H}$ NMR $\left(500 \mathrm{MHz}, \mathrm{CDCl}_{3}\right) \delta 1.17(\mathrm{~s}, 21 \mathrm{H}), 1.15(\mathrm{~s}, 21 \mathrm{H}), 1.36(\mathrm{~s}, 6 \mathrm{H}), 3.22(\mathrm{~s}, 2 \mathrm{H}), 4.03$ $(\mathrm{s}, 3 \mathrm{H}), 6.91(\mathrm{dd}, 1 \mathrm{H}, J=7.7,0.8 \mathrm{~Hz}), 7.39(\mathrm{t}, 1 \mathrm{H}, J=8.2 \mathrm{~Hz}), 7.60(\mathrm{dd}, 1 \mathrm{H}, J=8.5,1.1 \mathrm{~Hz}) ;{ }^{13} \mathrm{C} \mathrm{NMR}\left(125 \mathrm{MHz}, \mathrm{CDCl}_{3}\right) \delta$ $11.40,11.48,18.81,18.82,26.29,39.65,61.63,75.39,99.64,100.03,101.47,103.21,112.56,114.20,119.04,121.08,128.00$, 128.33, 130.62, 151.82, 158.26, one sp ${ }^{2} \mathrm{C}$ not located; IR (neat) $2943,2888,2145,1464 \mathrm{~cm}^{-1}$; mass spectrum (FAB) $\mathrm{m} / z(\%$ rel. int.) $588 \mathrm{M}^{+}$(100), 488 (60), 445 (20), 157 (19). Anal calcd for $\mathrm{C}_{37} \mathrm{H}_{56} \mathrm{O}_{2} \mathrm{Si}_{2}$ : C,75.45; H, 9.58. Found: C, 75.59; H, 9.56.

\section{Desilylation of 47a - Isolation of the Bis-Terminal Alkyne 47b.}

To a stirred solution of $47 \mathbf{a}(54 \mathrm{mg}, 0.09 \mathrm{mmol})$ in $5 \mathrm{~mL}$ THF at RT was added TBAF $(0.27 \mathrm{mmol}, 270 \mu \mathrm{L}, 1 \mathrm{M}$ solution in THF). After $5 \mathrm{~min}$ at RT, the reaction mixture was quenched with $5 \mathrm{~mL}$ water and diluted with EtOAc $(20 \mathrm{~mL})$. The organic layer was washed with $5 \mathrm{~mL}$ water, dried over $\mathrm{MgSO}_{4}$, concentrated in vacuo. The product was purified by silica gel column chromatography using hexane and EtOAc (20:1) as eluent to give $17 \mathrm{mg}$ of compound $\mathbf{4 7} \mathbf{b}$ (68\% yield) as a colorless oil. Spectral data for 47b: ${ }^{1} \mathrm{H}$ NMR $\left(500 \mathrm{MHz}, \mathrm{CDCl}_{3}\right) \delta 1.38(\mathrm{~s}, 6 \mathrm{H}), 3.20(\mathrm{~s}, 2 \mathrm{H}), 3.55(\mathrm{~s}, 1 \mathrm{H}), 3.61(\mathrm{~s}, 1 \mathrm{H}), 4.09$ $(\mathrm{s}, 3 \mathrm{H}), 6.95(\mathrm{dd}, 1 \mathrm{H}, J=6.9,1.0 \mathrm{~Hz}), 7.43(\mathrm{t}, 1 \mathrm{H}, J=7.8 \mathrm{~Hz}), 7.64(\mathrm{dd}, 1 \mathrm{H}, J=8.6,1.0 \mathrm{~Hz}) ;{ }^{13} \mathrm{C} \mathrm{NMR}\left(125 \mathrm{MHz}, \mathrm{CDCl}_{3}\right) \delta$ 26.88, 39.10, 61.89, 75.52, 78.75, 79.96, 85.20, 85.69, 112.81, 113.09, 114.29, 117.80, 121.16, 128.10, 128.75, 130.36, 151.95, 158.11; IR (neat) 3289, 2974, 2928, 2851, 1578, $1489 \mathrm{~cm}^{-1}$; mass spectrum (EI) $\mathrm{m} / \mathrm{z}$ (\% rel. int.) 276 (M+), 275 (47), 261 (42), 260 (48), 246 (30), 245 (23), 203 (65), 202 (67). Anal calcd for $\mathrm{C}_{19} \mathrm{H}_{16} \mathrm{O}_{2}$ : C, 82.58; H, 5.84; Found: C, 82.39; H, 5.62.

\section{Preparation of Bromochromane 59 via Reduction of 21.}

To a stirred solution of 21 (100 mg, $0.418 \mathrm{mmol}$ ) in $15 \mathrm{~mL}$ EtOH was added $50 \mathrm{mg}$ of $\mathrm{Rh}$ on alumina (5\% $\mathrm{Rh}$ on alumina). The reaction mixture was stirred for $2 \mathrm{~h}$ at RT under $\mathrm{H}_{2}$ atmosphere ( $\left.1 \mathrm{~atm}\right)$. After $2 \mathrm{~h}$, the reaction mixture was filtered through Celite and concentrated in vacuo. The product was purified by silica gel column chromatography using hexane and EtOAc (20:1) as eluent to give bromochromane 59 in 92\% yield as a colorless oil. Spectral data for 59: ${ }^{1} \mathrm{H}$ NMR (500 $\left.\mathrm{MHz}, \mathrm{CDCl}_{3}\right) \delta 1.32(\mathrm{~s}, 6 \mathrm{H}), 1.81(\mathrm{t}, 2 \mathrm{H}, J=6.8 \mathrm{~Hz}), 2.74(\mathrm{t}, 2 \mathrm{H}, J=6.9 \mathrm{~Hz}), 6.74(\mathrm{~d}, 1 \mathrm{H}, J=8.2 \mathrm{~Hz}), 6.95(\mathrm{t}, 1 \mathrm{H}, J=8.1$ $\mathrm{Hz}), 7.09(\mathrm{~d}, 1 \mathrm{H}, J=8.3 \mathrm{~Hz}) ;{ }^{13} \mathrm{C} \mathrm{NMR}\left(75 \mathrm{MHz}, \mathrm{CDCl}_{3}\right) \delta 23.85,26.47,32.75,74.30,116.50,121.27,123.44,125.19$, 127.93, 144.07; IR (neat) 2976.54, 2930, 1593, $1566 \mathrm{~cm}^{-1}$; mass spectrum (FAB) $\mathrm{m} / \mathrm{z}$ (\% rel. int.) 242 (96, $\left.{ }^{81} \mathrm{Br}\right), 240(100$, $\left.{ }^{79} \mathrm{Br}\right), 227\left(12,{ }^{81} \mathrm{Br}\right), 225\left(13,{ }^{79} \mathrm{Br}\right), 187\left(14,{ }^{81} \mathrm{Br}\right), 185$ (17, $\left.{ }^{79} \mathrm{Br}\right), 161$ (91), 146 (28), 145 (29). Anal calcd for $\mathrm{C}_{11} \mathrm{H}_{13} \mathrm{BrO}$ : C, 54.79; H, 5.43. Found: C, 54.66; H, 5.20.

\section{Synthesis of the Chromane Carbene Complex 60.}

To a flame-dried $100 \mathrm{~mL}$ round-bottomed flask containing a solution of bromochromane $\mathbf{5 9}$ (310 mg, $1.45 \mathrm{mmol})$ in ether $(10 \mathrm{~mL})$ at $-78{ }^{\circ} \mathrm{C}$ was added tert-BuLi $(1.7 \mathrm{~mL}, 2.90 \mathrm{mmol}, 1.7 \mathrm{M}$ solution in pentane). The mixture was warmed to 0 ${ }^{\circ} \mathrm{C}$, stirred for $5 \mathrm{~min}$ and then cooled to $-78^{\circ} \mathrm{C}$ before it was transferred by cannula to a suspension of $\mathrm{Cr}(\mathrm{CO})_{6}(350 \mathrm{~g}, 1.59$ mmol) in $10 \mathrm{~mL}$ ether maintained at $0{ }^{\circ} \mathrm{C}$. The reaction mixture turned dark red in $5 \mathrm{~min}$. Stirring was continued for $6 \mathrm{~h}$ at RT 
which was followed by removal of ether under vacuum. After addition of $10 \mathrm{~mL}$ dichloromethane, $\mathrm{Me}_{3} \mathrm{OBF}_{4}(1.63 \mathrm{~g}, 11$ mmol) was added at RT and the mixture allowed to stir for $2 \mathrm{~h}$. The reaction mixture was then filtered through Celite and concentrated in vacuo. The product was purified by silica gel column chromatography with 5\% EtOAc in hexane to give 344 $\mathrm{mg}$ (65\% yield) of carbene complex $\mathbf{6 0}$ as an orange solid. Spectral data for $\mathbf{6 0}: \mathrm{mp} 108{ }^{\circ} \mathrm{C} \mathrm{dec} ;{ }^{1} \mathrm{H} \mathrm{NMR}\left(500 \mathrm{MHz}, \mathrm{CDCl}_{3}\right)$ $\delta 1.32$ (s, 6H), 1.78 (br, s, 2H), 2.43 (br, s, 2H), 4.25 (br, s, 3H), 6.35 (d, 1H, J = 6.8 Hz), 6.70 (d, 1H, J = 7.8 Hz), 7.14 (d, 1H, $J=7.8 \mathrm{~Hz}) ;{ }^{13} \mathrm{C} \mathrm{NMR}\left(75 \mathrm{MHz}, \mathrm{CDCl}_{3}\right) \delta 19.94,26.82,32.25,65.47,74.23,110.11,111.44,117.12,127.56,154.05,216.00$, 224.22, 359.39, one $\mathrm{sp}^{2} \mathrm{C}$ not located; ); IR (neat) 2978, 2064, 1930, $1576 \mathrm{~cm}^{-1}$; mass spectrum (FAB) $\mathrm{m} / z$ (\% rel. int.) 396 $\mathrm{M}^{+}$(38), 368 (80), 312 (82), 284 (100), 256 (90), 205 (38), 189 (40). Anal calcd for $\mathrm{C}_{18} \mathrm{H}_{16} \mathrm{CrO}_{7}$ : C, 54.55; H, 4.07. Found: C, $54.66 ; \mathrm{H}, 3.96$.

\section{Reaction of the Chromane Carbene Complex 60 with 1-Pentyne.}

To a flame-dried $10 \mathrm{~mL}$ flask with the 14/20 joint replaced by a high-vacuum threaded Teflon stopcock was added chromane carbene complex $60(35 \mathrm{mg}, 0.088 \mathrm{mmol})$, benzene $(1.7 \mathrm{~mL}), 1$-pentyne (18 $\mu \mathrm{L}, 0.090 \mathrm{mmol}), \mathrm{TBSCl}(40 \mathrm{mg}, 0.264$ mmol) and N,N-diisopropylethylamine $(77 \mu \mathrm{L}, 0.440 \mathrm{mmol})$. The system was deoxygenated by the freeze-pump-thaw method ( -196 to $25^{\circ} \mathrm{C}, 3$ cycles). The flask was back-filled with argon at RT and sealed. The mixture was then stirred at $50{ }^{\circ} \mathrm{C}$ for 24 $\mathrm{h}$ and at RT for another $24 \mathrm{~h}$. The reaction was opened to air and allowed to stir for $12 \mathrm{~h}$. The reaction mixture was filtered through Celite, concentrated in vacuo and the product was purified by silica gel column chromatography using hexane and EtOAc (20:1) to give a 77\% yield of naphthodihydropyran $61(28 \mathrm{mg})$ as a colorless oil. Spectral data for 61: ${ }^{1} \mathrm{H}$ NMR (500 $\left.\mathrm{MHz}, \mathrm{CDCl}_{3}\right) \delta 0.11(\mathrm{~s}, 6 \mathrm{H}), 0.93(\mathrm{t}, 3 \mathrm{H}, J=7.3 \mathrm{~Hz}), 1.08(\mathrm{~s}, 9 \mathrm{H}), 1.34(\mathrm{~s}, 6 \mathrm{H}), 1.55-1.65(\mathrm{~m}, 2 \mathrm{H}), 1.79(\mathrm{t}, 2 \mathrm{H}, J=6.6 \mathrm{~Hz})$, 2.58-2.68 (m, 2H), $3.41(\mathrm{t}, 2 \mathrm{H}, J=6.8 \mathrm{~Hz}), 3.84(\mathrm{~s}, 3 \mathrm{H}), 6.59(\mathrm{~s}, 1 \mathrm{H}), 6.90(\mathrm{~d}, 1 \mathrm{H}, J=9.9 \mathrm{~Hz}), 7.77(\mathrm{~d}, 1 \mathrm{H}, J=9.3 \mathrm{~Hz}) ;{ }^{13} \mathrm{C}$ NMR (125 MHz, $\left.\mathrm{CDCl}_{3}\right) \delta-3.30,14.02,18.64,23.04,23.67,26.13,26.52,32.60,33.57$, 55.74, 72.98, 108.92, 113.69, 118.82, 122.68, 124.21, 125.00, 125.02, 142.20, 151.04, 151.83; IR (neat) 2957, 2930, 2858, 1603, $1460 \mathrm{~cm}^{-1}$; mass spectrum (FAB) $m / z$ (\% rel. int.) $415 \mathrm{M}^{+}+1$ (40), 414 (100), 413 (20), 400 (10), 399 (10), 357 (5); HRMS (FAB) calcd for $m / z \mathrm{C}_{25} \mathrm{H}_{38} \mathrm{O}_{3} \mathrm{Si}$ 414.2590, measd 414.2587.

\section{Reaction of the Chromane Carbene Complex 60 with Triyne 44.}

To a flame-dried $10 \mathrm{~mL}$ flask with the 14/20 joint replaced by a high-vacuum threaded Teflon stopcock was added chromane carbene complex 60 (50 mg, $0.126 \mathrm{mmol})$, bis-TIPS triyne $44(49 \mathrm{mg}, 0.127)$ and benzene $(2.6 \mathrm{~mL})$. The system was deoxygenated by the freeze-pump-thaw method ( -196 to $25^{\circ} \mathrm{C}, 3$ cycles). The flask was back-filled with argon at RT and sealed. The mixture was then stirred at $90{ }^{\circ} \mathrm{C}$ for $24 \mathrm{~h}$. The reaction was opened to air and allowed to stir for $2 \mathrm{~h}$. The reaction mixture was filtered through Celite, concentrated in vacuo and the product was purified by silica gel column chromatography using a 1:2 mixture of benzene and hexane to give chromanylfuran $\mathbf{6 2}(49 \mathrm{mg})$ in $63 \%$ yield as a brown oil. This compound decomposes quickly and as a result it was not possible to obtain a ${ }^{13} \mathrm{C}$ NMR spectrum. Spectral data for 62: ${ }^{1} \mathrm{H}$ NMR (300 
$\left.\mathrm{MHz}, \mathrm{CDCl}_{3}\right) \delta 1.11(\mathrm{~s}, 21 \mathrm{H}), 1.15(\mathrm{~s}, 21 \mathrm{H}), 1.37(\mathrm{~s}, 6 \mathrm{H}), 1.80(\mathrm{t}, 2 \mathrm{H}, J=6.6 \mathrm{~Hz}), 2.88(\mathrm{t}, 2 \mathrm{H}, J=6.6 \mathrm{~Hz}), 4.24(\mathrm{~s}, 3 \mathrm{H}), 6.82$ (dd, $1 \mathrm{H}, J=8.2,1.3 \mathrm{~Hz}), 7.09$ (t, $1 \mathrm{H}, J=8.0 \mathrm{~Hz}), 7.40$ (dd, $1 \mathrm{H}, J=7.6,1.3 \mathrm{~Hz}$ ); IR (neat) 2943, 2868, 2148, 1606, $1579 \mathrm{~cm}^{-1}$; mass spectrum (FAB) $m / z$ (\% rel. int.) $619 \mathrm{M}^{+}+1$ (38), $618 \mathrm{M}^{+}$(40), 591 (45), 578 (32). Anal calcd for $\mathrm{C}_{38} \mathrm{H}_{58} \mathrm{O}_{3} \mathrm{Si}_{2}: \mathrm{C}, 73.73$; H, 9.44; Found: C, 73.55; H, 9.62.

\section{Synthesis of the Tungsten Chromenyl Carbene Complex 63.}

To a flame-dried $100 \mathrm{~mL}$ round-bottomed flask containing a solution of bromochromene 21 (536 mg, $2.24 \mathrm{mmol}$ ) in ether $(20 \mathrm{~mL})$ at $-78{ }^{\circ} \mathrm{C}$ was added tert-BuLi $(2.6 \mathrm{~mL}, 4.48 \mathrm{mmol}, 1.7 \mathrm{M}$ solution in pentane). The reaction mixture was warmed to $0{ }^{\circ} \mathrm{C}$, stirred for $5 \mathrm{~min}$ and then cooled to $-78{ }^{\circ} \mathrm{C}$ before it was transferred by cannula to a suspension of $\mathrm{W}(\mathrm{CO})_{6}$ $(867 \mathrm{mg}, 2.46 \mathrm{mmol})$ in $10 \mathrm{~mL}$ ether maintained at $0{ }^{\circ} \mathrm{C}$. The resulting mixture was stirred for $6 \mathrm{~h}$ at $\mathrm{RT}$ and then the ether was removed under vacuum. After addition of $10 \mathrm{~mL}$ dichloromethane, $\mathrm{Me}_{3} \mathrm{OBF}_{4}(497 \mathrm{gm}, 3.36 \mathrm{mmol}$ ) was added at $\mathrm{RT}$ and the mixture stirred for $2 \mathrm{~h}$. This was followed by filtration through Celite, concentration in vacuo and purification by silica gel column chromatography with 5\% EtOAc in hexane to give $773 \mathrm{mg}$ (66\% yield) of carbene complex 63 as an orange solid. Spectral data for 63: $\mathrm{mp} 76-78{ }^{\circ} \mathrm{C} ;{ }^{1} \mathrm{H}$ NMR $\left(500 \mathrm{MHz}, \mathrm{CDCl}_{3}\right) \delta 1.41(\mathrm{~s}, 6 \mathrm{H}), 4.54(\mathrm{br}, \mathrm{s}, 3 \mathrm{H}), 5.65(\mathrm{~d}, 1 \mathrm{H}, J=9.8 \mathrm{~Hz}), 6.04$ $(\mathrm{d}, 1 \mathrm{H}, J=9.9 \mathrm{~Hz}), 6.49(\mathrm{~d}, 1 \mathrm{H}, J=6.9 \mathrm{~Hz}), 6.68(\mathrm{dd}, 1 \mathrm{H}, J=8.1,0.8 \mathrm{~Hz}), 7.11(\mathrm{t}, 1 \mathrm{H}, J=8.6 \mathrm{~Hz}) ;{ }^{13} \mathrm{C} \mathrm{NMR}(75 \mathrm{MHz}$, $\mathrm{CDCl}_{3}$ ) $\delta$ 27.64, 76.00, 77.20, 114.44, 111.86, 116.58, 118.48, 128.29, 132.00, 152.58, 196.77, three C s not located; IR (neat) 2980, 2071, 1925, $1442 \mathrm{~cm}^{-1}$; mass spectrum (FAB) m/z (\% rel. int.) $526 \mathrm{M}^{+}$(40), 498 (40), 469 (38),; 442 (50), 386 (25), 341 (20), 203(100). Anal calcd for $\mathrm{C}_{18} \mathrm{H}_{14} \mathrm{O}_{7} \mathrm{~W}: \mathrm{C}, 41.09 ; \mathrm{H}, 2.68$. Found: C, 41.49; H, 2.70.

\section{Reaction of the Tungsten Chromenyl Carbene Complex 63 with 3-Hexyne.}

To a flame-dried $10 \mathrm{~mL}$ flask with the 14/20 joint replaced by a high-vacuum threaded Teflon stopcock was added chromene carbene complex 63 (107 mg, $0.203 \mathrm{mmol})$, benzene $(4 \mathrm{~mL})$ and 3-hexyne ( $46 \mu \mathrm{L}, 0.406 \mathrm{mmol})$. The system was deoxygenated by the freeze-pump-thaw method (-196 to $25{ }^{\circ} \mathrm{C}, 3$ cycles). The flask was back-filled with argon at RT and sealed. The mixture was then stirred at $90{ }^{\circ} \mathrm{C}$ for $24 \mathrm{~h}$. After $24 \mathrm{~h}$, the reaction was opened to air and allowed to stir for $12 \mathrm{~h}$. The reaction mixture was filtered through Celite, concentrated in vacuo and the product was purified by silica gel column chromatography using hexane and benzene (5:2) to give $64(52 \mathrm{mg})$ in $91 \%$ yield as a colorless oil. Spectral data for 64: ${ }^{1} \mathrm{H}$ NMR $\left(500 \mathrm{MHz}, \mathrm{CDCl}_{3}\right) \delta 0.54(\mathrm{t}, 3 \mathrm{H}, J=7.3 \mathrm{~Hz}), 1.11(\mathrm{t}, 3 \mathrm{H}, J=7.6 \mathrm{~Hz}), 1.40(\mathrm{~s}, 3 \mathrm{H}), 1.43(\mathrm{~s}, 3 \mathrm{H}), 1.66-1.76(\mathrm{~m}, 1 \mathrm{H})$, 1.88-1.99 (m, 1H), 2.06-2.16 (m, 1H), 2.60-2.72 (m, 1H), $3.26(\mathrm{t}, 1 \mathrm{H}, J=4.8 \mathrm{~Hz}), 3.75(\mathrm{~s}, 3 \mathrm{H}), 5.61(\mathrm{~d}, 1 \mathrm{H}, J=9.8 \mathrm{~Hz}), 6.57$ $(\mathrm{d}, 1 \mathrm{H}, J=7.8 \mathrm{~Hz}), 7.01(\mathrm{~d}, 1 \mathrm{H}, J=10.3 \mathrm{~Hz}), 7.02(\mathrm{~d}, 1 \mathrm{H}, J=8.3 \mathrm{~Hz}) ;{ }^{13} \mathrm{C}$ NMR $\left(75 \mathrm{MHz}, \mathrm{CDCl}_{3}\right) \delta 8.34,14.19,18.10$, 22.40, 27.51, 27.97, 45.17, 60.37, 75.25, 112.35, 113.65, 119.26, 122.61, 130.14, 135.08, 135.89, 137.48, 151.70, 153.98; IR (neat) 2968, 2932, 2870, 1631, $1593 \mathrm{~cm}^{-1}$; mass spectrum (FAB) $\mathrm{m} / z$ (\% rel. int.) $285 \mathrm{M}^{+}+1$ (90), $284 \mathrm{M}^{+}$(100), 283 (70), 269 (80), 255 (30), 225 (30); HRMS (FAB) calcd for $m / z \mathrm{C}_{19} \mathrm{H}_{24} \mathrm{O}_{2} 284.1776$, found $284.1777\left(\mathrm{M}^{+}\right.$). 


\section{Reaction of the Tungsten Chromenyl Carbene Complex 63 with Triyne 44.}

To a flame-dried $10 \mathrm{~mL}$ flask with the 14/20 joint replaced by a high-vacuum threaded Teflon stopcock was added chromene carbene complex 63 (89 mg, $0.169 \mathrm{mmol})$, bis-TIPS triyne $44(49 \mathrm{mg}, 0.127)$ and toluene $(2.5 \mathrm{~mL})$. The system was deoxygenated by the freeze-pump-thaw method ( -196 to $25{ }^{\circ} \mathrm{C}, 3$ cycles). The flask was back-filled with argon at RT and sealed. The mixture was then stirred at $130{ }^{\circ} \mathrm{C}$ for $24 \mathrm{~h}$. The reaction was opened to air and allowed to stir for $12 \mathrm{~h}$. The reaction mixture was filtered through Celite and concentrated in vacuo and the residue was chromatographed using $2 \%$ ethylacetate in hexane which afforded $85 \mathrm{mg}$ of a mixture of compounds. The column was then flushed using a solvent gradient beginning with 5\% ethyl acetate in hexane and ending with neat ethyl acetate to give $9 \mathrm{mg}$ of a complex mixture which did not showed any aromatic protons in the ${ }^{1} \mathrm{H}$ NMR spectrum nor any distinct spot on the TLC plate. The $85 \mathrm{mg}$ fraction was again purified using $2.5 \%$ benzene in hexane which afforded three fractions: the first fraction and the third fraction which weighed $30 \mathrm{mg}$ and $18 \mathrm{mg}$, respectively showed very faint peaks in the aromatic region in the ${ }^{1} \mathrm{H}$ NMR spectrum. The second fraction $(30 \mathrm{mg}$ ) consisted of two compounds; complex 63 and the olefin-addition product $47 \mathbf{a}$ in the ratio of $10: 1$. The second fraction had a ${ }^{1} \mathrm{H}$ NMR spectrum that had the presence of all the absorptions observed for pure samples of 47a and 63 . 


\section{Theoretical Study on the Reaction of Complex 20 with Triyne 44.}

Theoretical calculations were performed using the Spartan 5.1.3 program. Initially the geometries of the proposed organometallic intermediates, reactants and final products outlined in Scheme 15 of the text were fully optimized by semi empirical PM3tm method. The PM3tm-optimized geometries were subjected to BP86 single point (SP) calculations with DN* basis set (comparable in size to Pople 6-31g* basis set) as implemented in the Spartan program. Tips groups were substituted with TMS groups to save computational time. PM3tm heats of formation were used only to compare energies of closely related intermediates and should be treated with caution. PM3tm heats of formation, (SP) BP86 relative energies of reactants, products and intermediates are presented in Table 7.

We tested the method on the intermediates from the benzannulation reaction of the unsubstituted vinyl carbene complex with ethyne and compared the results with those reported by Hess and coworkers. ${ }^{1}$ The present method would be expected to be less accurate that those from pure BP86/SVP, nonetheless, we found the same trend; the energy decreased in the order of $\eta^{1}, \eta^{3}$-vinyl carbene complex, vinyl ketene complex and arene chromium tricarbonyl complex. Reactant stability was, however, overestimated, yielding a smaller value for the overall energy release (58 instead of $63 \mathrm{kcal})$. The loss in accuracy is compensated by the significantly shorter computational time which then allows for the treatment of larger molecules in the present study.

In course of the reaction the chromium tricarbonyl fragment normally ends up coordinated to an electron-rich aromatic ring in the product. In the case of the olefin insertion product 47a (Scheme 15) the product isolated has lost the chromium tricarbonyl unit presumably due to ligand displacement or air oxidation. This is also generally true for furan, indene and cyclopropane products of the type 46,54 and 57. This is also often true for phenol products of the type 45 upon exposure of the reaction mixture to air. In addition, the starting materials and products also differ by one or two carbon monoxide ligands. Therefore, to relate the energies of the starting materials and the various intermediates with those of the various products, the energy of each product is summed with the energy of the proper number of molecules of carbon monoxide (one or two) and with the energy of benzene chromium tricarbonyl 64 and the energies of the starting materials are summed with the energy of benzene.

Analysis of the data in the Table 7 reveals that all four reactions under consideration are exothermic with 2,3-dihydrobenzo[de]chromene 47a being the most stable $(-18 \mathrm{kcal} / \mathrm{mol})$, followed by naphthol $45(-10 \mathrm{kcal} / \mathrm{mol})$, and furan $46(0.0 \mathrm{kcal} / \mathrm{mol})$. Indene 54 is less stable than furan 46 by $7.6 \mathrm{kcal} / \mathrm{mol}$, but still having less energy than reactants (18 kcal/mol). The cyclopropane 57 appears to be highly strained and would not be expected to be a product from this 
reaction. All of the possible reactions are expected to proceed via high energy intermediates with highly exothermic last steps. Therefore, all four processes should be irreversible, and it is reasonable to suggest that kinetic barriers will determine which product is being formed.

Table 7. Relative Energies of Reactants, Products and Intermediates from Reaction of 20 and 44.

\begin{tabular}{|c|c|c|c|}
\hline Entry & Compound & $\begin{array}{l}\text { Heat of formation } \\
\text { PM3tm, kcal/mol }\end{array}$ & $\begin{array}{l}\text { Energy, } \\
\text { kcal/mol }\end{array}$ \\
\hline 1 & $20+44$ & - & $17.9^{1}$ \\
\hline 3 & 45 & - & $-9.7^{2}$ \\
\hline 4 & 46 & - & $0.0^{2}$ \\
\hline 5 & 47 & - & $-18.0^{3}$ \\
\hline 6 & $(E)-50$ & -115 & 34.5 \\
\hline 7 & $(Z)-50$ & -115 & 84.9 \\
\hline 8 & 51 & -87 & 100.3 \\
\hline 9 & 52 & -82 & 94.4 \\
\hline 10 & 53 & -41 & 99.1 \\
\hline 11 & 54 & -22 & $7.6^{3}$ \\
\hline 12 & 55 & -129 & 77.6 \\
\hline 13 & 56 & -114 & $41.9^{3}$ \\
\hline 14 & 57 & 66 & 92.4 \\
\hline 15 & 58 & -124 & 79.6 \\
\hline
\end{tabular}

${ }^{1}$ Also includes the energy of benzene. ${ }^{2}$ Also includes the energy of $\mathrm{CO}$ and benzene chromium tricarbonyl 64. ${ }^{3}$ Also includes the energy of 2 CO's and 64.

The three intermediat $₫ S)-(\mathbf{5 0},(Z)-\mathbf{5 0}$ and $\mathbf{5 5}$ differ by only by a coordination to a different double-bond or to a different stereoisomer of the same double-bond. The $\eta^{1}, \eta^{3}$-vinyl carbene complexed intermediate $(E)$-50 with relative energy of $34 \mathrm{kcal} / \mathrm{mol}$ is the most stable among these species. The vinyl ketene complex $\mathbf{5 1}$ is the least stable of all of the reaction intermediates shown in Scheme 15. Interestingly enough, the reaction outcome correlates pretty well with the calculated relative stabilities of the reaction intermediates. A possible explanation could be drawn along the lines of the Hammond postulate. One can argue that as energy goes up hill, the associated transition state also is further uphill and the reaction rate would thereby correlate the with thermodynamics of that step. Thus, a route via complex $\mathbf{5 5}$ through to the abnormal product $\mathbf{4 7} \mathbf{a}$ emerges as the most kinetically accessible, since all post branching intermediates $\mathbf{5 5}, \mathbf{5 6}$ and $\mathbf{5 8}$ on the way to 47 a would be lower in energy than the intermediate $\mathbf{5 2}$ on the path to furan 46 (Figure 1), and lower than the 
intermediate $\mathbf{5 1}$ on the way to phenol $\mathbf{4 5}$ (not shown in Figure 1) and lower than intermediate $\mathbf{5 3}$ on the way to indene $\mathbf{5 4}$ (not shown in Figure 1).

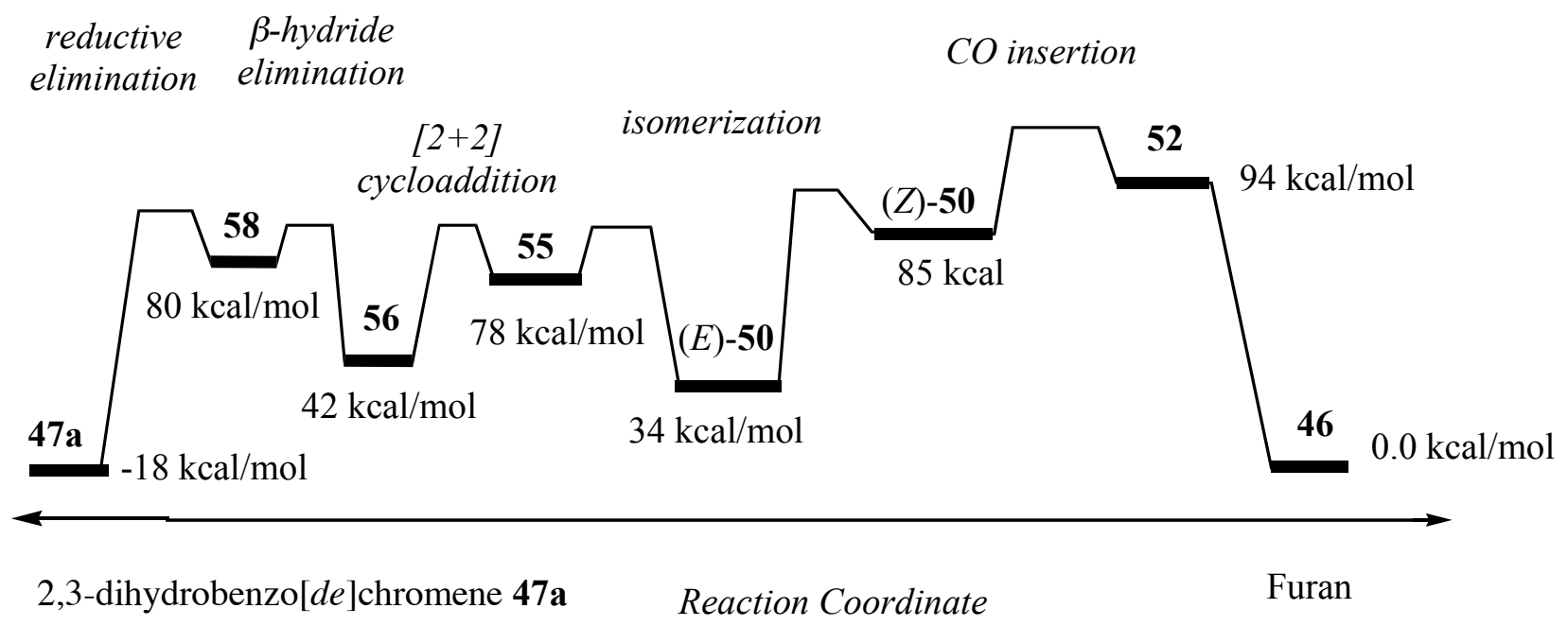

Figure 1. Reaction Manifold for the formation of Furan $\mathbf{4 6}$ and Chromene 47a.

In absence of the double bond in the pyran ring, there is no possibility for thformation of intermediate $\mathbf{5 5}$ and then the second kinetically most plausible route would be expected to occur. takes precedence over the naphthol formation. The vinyl ketene complex 51 is higher in energy than its isomer 52 (Scheme 15). Thus the higher energy of the CO insertion transition state for naphthol formation would be in agreement with our experimental observations.

It should be emphasized that these calculations werperformd by initial optimization of the geometries with PM3tm and then single point energy calculations with DFT methods. Energy calculations with the PM3tm method gave energies that were wildly divergent from the relative energies for the various intermediates that were calculated by Hess and Dötz. Employing PM3tm for geometries and then DFT for energies gave results where the relative energies of all the key intermediates matched those of Hess and Dötz. This method thus was performed to give the correct relative, if not absolute energies. For example, the energy difference $50 \mathrm{Kcal} /$ mole between the $\mathrm{E}$ and $\mathrm{Z}$ isomers of the vinyl carbene complexed intermediate $\mathbf{5 0}$ is not realistic since products are observed from each. To get a handle on a more precise energy difference between the two, higher level calculations were done with ONIOM(B3LYP/LanI2DZ:HF/STO-3G) and it was found that a more reasonable energy difference of $5 \mathrm{Kcal} / \mathrm{mole}$ was predicted. While this method gives more precise energies for organometallic systems, it is very time consuming and expensive to do which has prohibited us from doing this on each intermediate. 
In conclusion, experimental data and the computational study both suggest that the reaction proceeds through high-energy intermediates and operates under kinetic control. The kinetic barriers can be associated with the stability of key intermediates - vinyl ketenes complexes 51, 52, Casey's intermediate $\mathbf{5 3}$ and the chelated chromium carbene complex $\mathbf{5 8 .}$

\section{Computational details, Spartan output files}

The relative energy was obtained by deducting the sum of single point energies (SPE) of furan $46, \mathrm{C}_{6} \mathrm{H}_{6} \mathrm{Cr}(\mathrm{CO})_{3} \mathbf{6 4}$ and CO from energy of reactants and intermediates as follows.

$\mathrm{E}($ Reactants $)=$ SPE $20+$ SPE $44+$ SPE benzene - [SPE 46 - SPE 64 -SPE CO]

E 45 = SPE $45-$ SPE 46

$\mathrm{E}(E)-\mathbf{5 0}=\mathrm{SPE}(E)-\mathbf{5 0}+\mathrm{SPE}$ benzene $+\mathrm{SPE} \mathrm{CO}-[\mathrm{SPE} \mathbf{4 6}-\mathrm{SPE}$ 64-SPE CO]

The same formula was used for $(Z)-\mathbf{5 0}, \mathbf{5 1}, \mathbf{5 2}, \mathbf{5 5}, \mathbf{5 6}, \mathbf{5 8}$.

E 53 = SPE 53 + SPE benzene + 2 SPE CO - [SPE 46 -SPE $64-$ SPE CO $]$

E 54 = SPE $54+$ SPE CO -SPE 46

The last formula was used also for $\mathbf{4 7 a}$ and $\mathbf{5 7}$.

Table 8. Relative Energies and SPE from the Reaction of 20 and 44.

\begin{tabular}{|l|l|l|l|l|}
\hline Entry & Compound & $\begin{array}{l}\text { Heat of formation } \\
\text { PM3tm, kcal/mol }\end{array}$ & $\begin{array}{l}\text { SP BP86 } \\
\text { Energy. (h/p) }\end{array}$ & Energy. kcal/mol \\
\hline 1 & $\mathbf{2 0}+\mathbf{4 4}$ & - & -3545.70415 & $17.9^{1}$ \\
\hline 3 & $\mathbf{4 5}$ & - & -3545.7480 & $-9.7^{2}$ \\
\hline 4 & $\mathbf{4 6}$ & - & -3545.7326 & $0.0^{2}$ \\
\hline 5 & $\mathbf{4 7}$ & - & -3545.7613 & $-18.0^{3}$ \\
\hline 6 & $(E)-\mathbf{5 0}$ & -115 & -3200.0016 & 34.5 \\
\hline 7 & $(Z)-\mathbf{5 0}$ & -115 & -3199.9212 & 84.9 \\
\hline 8 & $\mathbf{5 1}$ & -87 & -3199.8967 & 100.3 \\
\hline 9 & $\mathbf{5 2}$ & -82 & -3199.9060 & 94.4 \\
\hline 10 & $\mathbf{5 3}$ & -40.5 & -3086.5368 & 99.1 \\
\hline 11 & $\mathbf{5 4}$ & -22 & -1701.7485 & $7.6^{3}$ \\
\hline 12 & $\mathbf{5 5}$ & -129 & -3199.9329 & 77.6 \\
\hline 13 & $\mathbf{5 6}$ & -114 & -3199.9897 & 41.9 \\
\hline 14 & $\mathbf{5 7}$ & 66 & -1701.6134 & $92.4^{3}$ \\
\hline 15 & $\mathbf{5 8}$ & 23 & -3199.9296 & 79.6 \\
\hline 16 & PhH & -232.3143 & - \\
\hline
\end{tabular}




\begin{tabular}{|l|l|l|l|l|}
\hline 17 & $\mathrm{C}_{6} \mathrm{H}_{6} \mathrm{Cr}(\mathrm{CO})_{3} \mathbf{6 4}$ & -46 & -1617.2484 & - \\
\hline 18 & $\mathrm{CO}$ & -19.7 & -113.3618 & - \\
\hline
\end{tabular}

${ }^{1}$ Also includes the energy of benzene. ${ }^{2}$ Also includes the energy of $\mathrm{CO}$ and benzene chromium tricarbonyl $64 .{ }^{3}$ Also includes the energy of 2 CO's and 64.

Chromium Fisher carbene complex 20.

begin Wed Mar 30 18:02:05 2005 on Coulson
run type: $\quad$ ENERGY
model: NLSDA/BP86/DN*
number of shells: 188
$\quad$ 108 S shells
$\quad$ 53 P shells
$\quad 27$ D shells

number of valence orbitals: 402

point group symmetry used: $\mathrm{C} 1$

spin multiplicity: $\quad 1$

cartesian coordinates (angstroms)

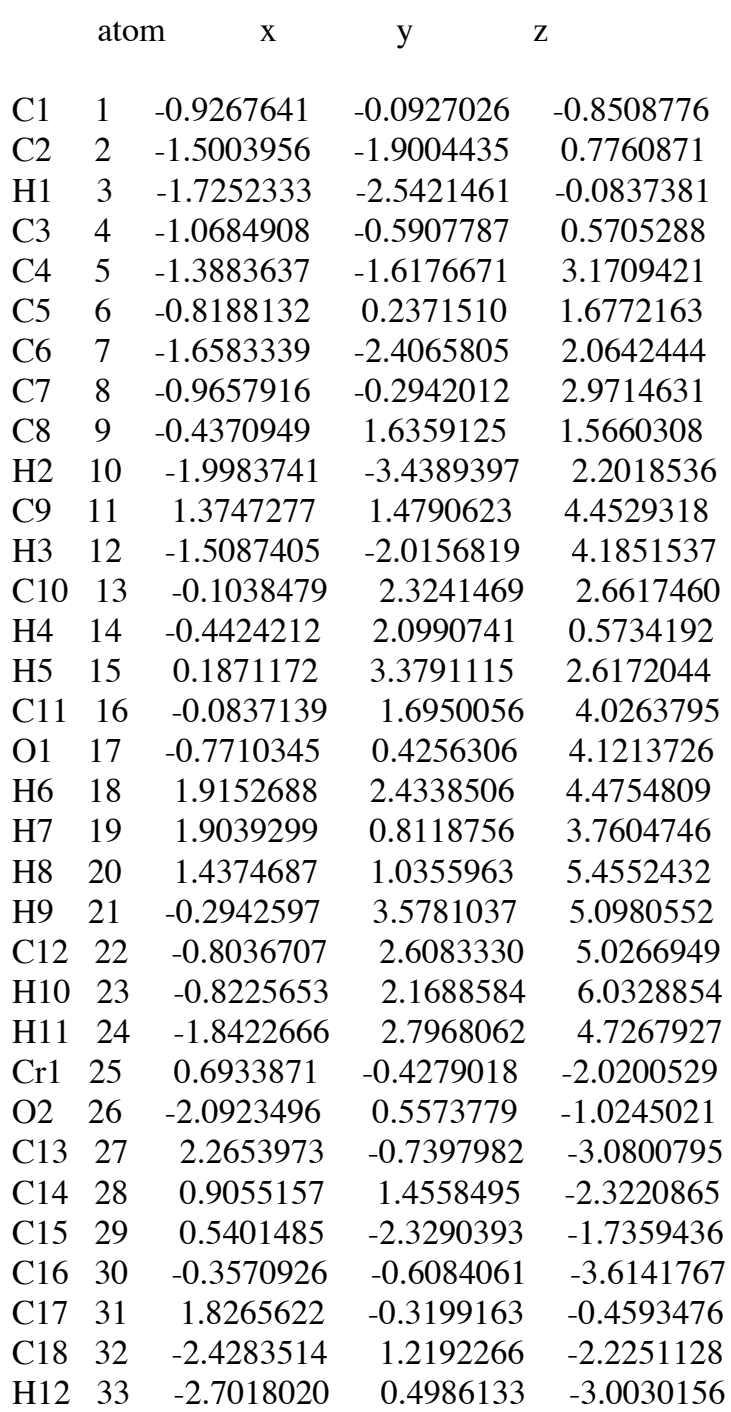




$\begin{array}{lccrc}\text { H13 } & 34 & -1.6297385 & 1.8777532 & -2.5848778 \\ \text { H14 } & 35 & -3.3028728 & 1.8075045 & -1.9329351 \\ \text { O3 } & 36 & 3.2193427 & -0.9234641 & -3.7254555 \\ \text { O4 } & 37 & 1.0604758 & 2.5977158 & -2.5045082 \\ \text { O5 } & 38 & 2.5533569 & -0.2687495 & 0.4478957 \\ \text { O6 } & 39 & -0.9428558 & -0.7509667 & -4.6142643 \\ \text { O7 } & 40 & 0.4672442 & -3.4815014 & -1.5881095\end{array}$

stoichiometry: $\quad \mathrm{CrO} 7 \mathrm{C} 18 \mathrm{H} 14$

molecular charge $\quad 0.0$

number of electrons $\quad 202.0$

integration mesh: $\quad$ FINE

integration points and checksum: 171248201.999986

$\mathrm{E}(\mathrm{DFT})=-2266.14005 \quad \mathrm{BP} 86$

total time: $283 \mathrm{~min} .41 .4 \mathrm{sec}$.

end Wed Mar 30 22:55:47 2005

\section{Bis-Trimethylsilyl analog of Triyne $\mathbf{4 4}$}

begin Tue Mar 29 09:50:37 2005 on pauling

run type: ENERGY

model: $\quad$ NLSDA/BP86/DN*

number of shells: $\quad 124$

$80 \mathrm{~S}$ shells

$30 \mathrm{P}$ shells

$14 \mathrm{D}$ shells

number of valence orbitals: 240

point group symmetry used: $\mathrm{C} 2 \mathrm{~V}$

spin multiplicity:

cartesian coordinates (angstroms)

\begin{tabular}{|c|c|c|c|c|}
\hline \multicolumn{3}{|c|}{ atom } & \multicolumn{2}{|l|}{ t } \\
\hline Sil & 1 & 4.9210497 & 0.0000000 & 0.0000000 \\
\hline $\mathrm{C} 1$ & 2 & 3.1667685 & 0.0000000 & 0.0000000 \\
\hline $\mathrm{C} 2$ & 3 & 1.9656087 & 0.0000000 & 0.0000000 \\
\hline C3 & 4 & 0.5993750 & 0.0000000 & 0.0000000 \\
\hline $\mathrm{C} 4$ & 5 & -0.5993750 & 0.0000000 & 0.0000000 \\
\hline $\mathrm{C} 5$ & 6 & -1.9656087 & 0.0000000 & 0.0000000 \\
\hline C6 & 7 & -3.1667685 & 0.0000000 & 0.0000000 \\
\hline $\mathrm{Si} 2$ & 8 & -4.9210497 & 0.0000000 & 0.0000000 \\
\hline C7 & 9 & 5.5430159 & -1.5501199 & 0.8949621 \\
\hline $\mathrm{C} 8$ & 10 & 5.5430159 & 0.0000000 & -1.7899243 \\
\hline C9 & 11 & 5.5430159 & 1.5501199 & 0.8949621 \\
\hline $\mathrm{C} 10$ & 12 & -5.5430159 & -1.5501199 & 0.8949621 \\
\hline C11 & 13 & -5.5430159 & 1.5501199 & 0.8949621 \\
\hline C12 & 14 & -5.5430159 & 0.0000000 & -1.7899243 \\
\hline H1 & 15 & 6.6363265 & -1.5716353 & 0.9073840 \\
\hline $\mathrm{H} 2$ & 16 & 5.1920198 & -2.4583170 & 0.3982196 \\
\hline $\mathrm{H} 3$ & 17 & 5.1920198 & -1.5740268 & 1.9298552 \\
\hline H4 & 18 & 5.1920198 & 0.8842902 & -2.3280748 \\
\hline H5 & 19 & 5.1920198 & -0.8842902 & -2.3280748 \\
\hline
\end{tabular}




$\begin{array}{lcccc}\text { H6 } & 20 & 6.6363265 & 0.0000000 & -1.8147681 \\ \text { H7 } & 21 & 5.1920198 & 2.4583170 & 0.3982196 \\ \text { H8 } & 22 & 6.6363265 & 1.5716353 & 0.9073840 \\ \text { H9 } & 23 & 5.1920198 & 1.5740268 & 1.9298552 \\ \text { H10 } & 24 & -6.6363265 & -1.5716353 & 0.9073840 \\ \text { H11 } & 25 & -5.1920198 & -1.5740268 & 1.9298552 \\ \text { H12 } & 26 & -5.1920198 & -2.4583170 & 0.3982196 \\ \text { H13 } & 27 & -5.1920198 & 2.4583170 & 0.3982196 \\ \text { H14 } & 28 & -5.1920198 & 1.5740268 & 1.9298552 \\ \text { H15 } & 29 & -6.6363265 & 1.5716353 & 0.9073840 \\ \text { H16 } & 30 & -5.1920198 & 0.8842902 & -2.3280748 \\ \text { H17 } & 31 & -6.6363265 & 0.0000000 & -1.8147681 \\ \text { H18 } & 32 & -5.1920198 & -0.8842902 & -2.3280748\end{array}$

stoichiometry: $\mathrm{Si} 2 \mathrm{C} 12 \mathrm{H} 18$

molecular charge $\quad 0.0$

number of electrons $\quad 118.0$

integration mesh: $\quad$ FINE

integration points and checksum: $33133 \quad 118.000012$

$\mathrm{E}(\mathrm{DFT})=\quad-1047.24979 \quad \mathrm{BP} 86$

total time: $2 \mathrm{~min} .41 .3 \mathrm{sec}$.

end Tue Mar 29 09:53:28 2005

\section{Phenol 45}

begin Fri Apr 1 10:46:27 2005 on pauling

run type: $\quad$ ENERGY

model: NLSDA/BP86/DN*

number of shells: $\quad 254$

$159 \mathrm{~S}$ shells

$64 \mathrm{P}$ shells

$31 \mathrm{D}$ shells

number of valence orbitals: 506

point group symmetry used: $\mathrm{C} 1$

spin multiplicity:

cartesian coordinates (angstroms)

\begin{tabular}{|c|c|c|c|c|}
\hline & \multicolumn{2}{|c|}{ atom } & \multicolumn{2}{|l|}{$y$} \\
\hline H1 & 1 & 4.2947857 & -1.4071375 & 3.1610025 \\
\hline $\mathrm{H} 2$ & 2 & 0.7809760 & -0.5012655 & 5.4391796 \\
\hline $\mathrm{H} 3$ & 3 & -1.4096761 & 3.0426553 & -3.1287158 \\
\hline $\mathrm{C} 1$ & 4 & -1.0030325 & 1.2510582 & -1.9479566 \\
\hline $\mathrm{C} 2$ & 5 & 0.1254269 & -0.1232813 & 0.2560153 \\
\hline $\mathrm{C} 3$ & 6 & -1.1737554 & -0.1505918 & -1.8400563 \\
\hline C4 & 7 & -0.2736915 & 1.9549264 & -0.9361129 \\
\hline C5 & 8 & 0.2699842 & 1.2903836 & 0.1559184 \\
\hline C6 & 9 & -0.5544515 & -0.8232687 & -0.7316136 \\
\hline C7 & 10 & -1.9595325 & -0.8123029 & -2.8358627 \\
\hline $\mathrm{O} 1$ & 11 & -0.1529016 & 3.3038800 & -1.1096567 \\
\hline $\mathrm{C} 8$ & 12 & 0.9691068 & 2.0008281 & 1.1614328 \\
\hline $\mathrm{O} 2$ & 13 & -0.7250132 & -2.2024749 & -0.5982526 \\
\hline C9 & 14 & 0.7011507 & -0.7726119 & 1.3772671 \\
\hline $\mathrm{H} 4$ & 15 & 3.5639789 & -0.1070510 & 4.1140655 \\
\hline
\end{tabular}




\begin{tabular}{|c|c|c|c|c|}
\hline $\mathrm{H} 5$ & 16 & 1.2696326 & -2.0309823 & \\
\hline & 17 & 1143469 & -4.3178224 & 4421880 \\
\hline & 18 & .5749021 & 2959782 & 412254 \\
\hline 8 & 19 & 4.1243943 & -1.5861191 & 137186 \\
\hline & 20 & & & \\
\hline 10 & 21 & -2.4751527 & -0.0890246 & \\
\hline 11 & 22 & -2.2955017 & -2.2232318 & \\
\hline & 23 & -3.2396584 & -0.6116361 & -4.9095455 \\
\hline 12 & 24 & -2.2707846 & 1.3134029 & -4.0197761 \\
\hline & 25 & -1.5576846 & & 517209 \\
\hline & 26 & 6733 & & 3501 \\
\hline & 27 & & & \\
\hline 14 & 28 & & & \\
\hline 12 & 29 & & & 304 \\
\hline & 30 & & 964 & 666 \\
\hline & 31 & & 494 & 1125 \\
\hline & 32 & $-2.9^{\prime}$ & -2.8018654 & 27031 \\
\hline & 33 & -1.9 & & \\
\hline & 34 & & & \\
\hline & 35 & & & \\
\hline & 36 & & & \\
\hline 18 & 37 & -2.6 & 253 & \\
\hline 17 & 38 & -2.8 & 7645 & 996 \\
\hline 18 & 39 & -2.7 & 7279 & 1651 \\
\hline & 40 & -1.5 & 7840 & 10563 \\
\hline 20 & 41 & -5.2 & -1.7 & -6 \\
\hline & 42 & -5.5 & & 5109 \\
\hline 22 & 43 & & & \\
\hline & 44 & & & \\
\hline & 45 & 2.4 & & \\
\hline 20 & 46 & & 797 & 823 \\
\hline & 47 & 1.93 & -1.9 & 1582 \\
\hline & 48 & & & 446 \\
\hline 22 & 49 & 525 & 206 & 005 \\
\hline 23 & 50 & & & 461 \\
\hline 24 & 51 & & & \\
\hline & 52 & & & \\
\hline & 53 & & & \\
\hline 23 & 54 & & & 6149 \\
\hline & 55 & 2.3952254 & 0859264 & 5.8121514 \\
\hline & 56 & & 8264 & 5.0050255 \\
\hline & 57 & 4755 & 0349 & 2.1576675 \\
\hline 27 & 58 & 2780 & 1.9362848 & 3.1861065 \\
\hline & 59 & & & \\
\hline & 60 & & & 3.3978037 \\
\hline & 61 & & 5.6597289 & 2.3265097 \\
\hline & 62 & & & \\
\hline & 63 & -0.1645496 & -1.9695525 & 5.1506276 \\
\hline
\end{tabular}

stoichiometry: $\quad \mathrm{Si} 2 \mathrm{O} 3 \mathrm{C} 26 \mathrm{H} 32$

molecular charge $\quad 0.0$

number of electrons $\quad 240.0$

integration mesh: $\quad$ FINE

integration points and checksum: 252034239.999852

$\mathrm{E}(\mathrm{DFT})=\quad-1815.13783 \quad$ BP86

total time: $100 \mathrm{~min} .37 .3 \mathrm{sec}$.

end Fri Apr 1 12:32:54 2005 


\section{Furan 46}

begin Thu Jul 15 02:09:19 2004 on boys run type: ENERGY model: NLSDA/BP86/DN* number of shells: $\quad 254$ $159 \mathrm{~S}$ shells $64 \mathrm{P}$ shells $31 \mathrm{D}$ shells number of valence orbitals: 506 point group symmetry used: $\mathrm{C} 1$ spin multiplicity: $\quad 1$

cartesian coordinates (angstroms)

\begin{tabular}{|c|c|c|c|c|}
\hline & ato & $\mathrm{m}$ & $\mathrm{y}$ & $\mathrm{z}$ \\
\hline $\mathrm{O} 1$ & 1 & 0.5011822 & 0.5668819 & -2.3539339 \\
\hline C1 & 2 & -2.1355538 & 2.1434387 & -0.6526926 \\
\hline $\mathrm{C} 2$ & 3 & -0.7425545 & 2.0328722 & -0.8182584 \\
\hline H1 & 4 & -3.8033897 & 3.4419173 & -0.2310561 \\
\hline $\mathrm{H} 2$ & 5 & -2.7726292 & 1.2665903 & -0.7559970 \\
\hline C3 & 6 & 0.0642284 & 3.1847845 & -0.6848120 \\
\hline H3 & 7 & -2.3863745 & 5.4641851 & -0.0037039 \\
\hline C4 & 8 & -1.9316446 & 4.5041250 & -0.2332910 \\
\hline H4 & 9 & 3.3220548 & -5.9211017 & -0.8979067 \\
\hline $\mathrm{C} 5$ & 10 & -2.7267465 & 3.3706188 & -0.3590884 \\
\hline C6 & 11 & 2.2091282 & 6.4095764 & 0.5593486 \\
\hline C7 & 12 & -0.5478084 & 4.4147944 & -0.4004999 \\
\hline Sil & 13 & 0.9950534 & -5.6277737 & -0.0781744 \\
\hline C8 & 14 & 2.8178120 & -6.0487636 & 0.0646953 \\
\hline C9 & 15 & 2.1964771 & 4.3036048 & -0.7485148 \\
\hline $\mathrm{C} 10$ & 16 & 1.5268247 & 5.6445043 & -0.5813195 \\
\hline $\mathrm{O} 2$ & 17 & 0.1287064 & 5.5931143 & -0.2390692 \\
\hline H5 & 18 & 3.2773226 & 6.5633939 & 0.3704681 \\
\hline H6 & 19 & 2.1013305 & 5.8720667 & 1.5092985 \\
\hline H7 & 20 & 1.7415208 & 7.3903941 & 0.7062245 \\
\hline H8 & 21 & 2.6896567 & 6.5960100 & -2.1780915 \\
\hline C11 & 22 & 1.6453731 & 6.4462889 & -1.8825823 \\
\hline H9 & 23 & 1.1715308 & 7.4295462 & -1.7794442 \\
\hline H10 & 24 & 1.1254367 & 5.9392345 & -2.7042966 \\
\hline H11 & 25 & -2.3377840 & -3.3156091 & 4.8190845 \\
\hline H12 & 26 & 0.3041998 & -7.8172273 & -1.0221690 \\
\hline $\mathrm{C} 12$ & 27 & 0.1744261 & -5.8737505 & 1.5931506 \\
\hline H13 & 28 & -4.0916065 & 0.1990276 & 3.1547876 \\
\hline H14 & 29 & -4.4054079 & -1.0707308 & 4.3510781 \\
\hline H15 & 30 & 3.3091667 & -5.4015743 & 0.7974177 \\
\hline H16 & 31 & 0.2824487 & -6.9103131 & 1.9260253 \\
\hline C13 & 32 & -0.2446437 & -0.4424922 & -0.4640095 \\
\hline H17 & 33 & -0.8218632 & -3.3416017 & 3.9008022 \\
\hline
\end{tabular}




$\begin{array}{lcccc}\mathrm{C} 14 & 34 & -0.8464708 & -0.6853135 & 0.7906994 \\ \mathrm{C} 15 & 35 & -0.1966865 & 0.7131836 & -1.1406043 \\ \mathrm{C} 16 & 36 & 0.1940639 & -6.7730863 & -1.3299508 \\ \mathrm{H} 18 & 37 & -0.8741006 & -6.5564303 & -1.4261289 \\ \mathrm{C} 17 & 38 & 0.4623149 & -1.4205815 & -1.2628725 \\ \mathrm{H} 19 & 39 & 0.6573339 & -6.6566868 & -2.3143252 \\ \mathrm{H} 20 & 40 & 2.9493190 & -7.0869942 & 0.3838733 \\ \mathrm{C} 18 & 41 & 0.8866472 & -0.7897278 & -2.3675262 \\ \mathrm{O} 3 & 42 & 1.6033379 & -1.3686282 & -3.3843641 \\ \mathrm{H} 21 & 43 & -1.7339465 & -0.4351514 & 5.7554371 \\ \mathrm{H} 22 & 44 & -0.2158235 & -0.4480267 & 4.8409823 \\ \mathrm{C} 19 & 45 & -1.3546766 & -0.9063157 & 1.8553740 \\ \mathrm{~S} 2 & 46 & -2.1022718 & -1.2613279 & 3.4439588 \\ \mathrm{C} 20 & 47 & -1.2857045 & -0.2273202 & 4.7792335 \\ \mathrm{C} 21 & 48 & -3.9342615 & -0.8586671 & 3.3866605 \\ \mathrm{C} 22 & 49 & -1.8832872 & -3.0804986 & 3.8520684 \\ \mathrm{C} 23 & 50 & 0.6550796 & -2.7772430 & -0.9196221 \\ \mathrm{C} 24 & 51 & 0.8003717 & -3.9244349 & -0.5968727 \\ \mathrm{H} 23 & 52 & 3.2785551 & 4.2875244 & -0.8479938 \\ \mathrm{C} 25 & 53 & 1.5225827 & 3.1510003 & -0.7916507 \\ \mathrm{H} 24 & 54 & -4.4388448 & -1.4559974 & 2.6213178 \\ \mathrm{H} 25 & 55 & 2.0411954 & 2.2070785 & -0.9088295 \\ \mathrm{H} 26 & 56 & -1.4037066 & 0.8401130 & 4.5697460 \\ \mathrm{H} 27 & 57 & -0.8933963 & -5.6415437 & 1.5382963 \\ \mathrm{H} 28 & 58 & 0.6283226 & -5.2233406 & 2.3468747 \\ \mathrm{H} 29 & 59 & -2.3557688 & -3.7082844 & 3.0905980 \\ \mathrm{C} 26 & 60 & 1.8969265 & -0.4578010 & -4.4367095 \\ \mathrm{H} 30 & 61 & 2.4631643 & -0.9967161 & -5.2020944 \\ \mathrm{H} 31 & 62 & 2.5166211 & 0.3707959 & -4.0769374 \\ \mathrm{H} 32 & 63 & 0.9774024 & -0.0808429 & -4.8975007\end{array}$

stoichiometry: $\mathrm{Si} 2 \mathrm{O} 3 \mathrm{C} 26 \mathrm{H} 32$

molecular charge $\quad 0.0$

number of electrons $\quad 240.0$

integration mesh: FINE

integration points and checksum: 252382239.999992

$\mathrm{E}(\mathrm{DFT})=\quad-1815.12242 \quad \mathrm{BP} 86$

total time: $520 \mathrm{~min} .14 .8 \mathrm{sec}$.

end Thu Jul 15 11:37:17 2004

\section{Naphthalene Derivative 47a}

begin Fri Jul 2 04:42:15 2004 on pauling

run type: $\quad$ ENERGY

model: $\quad$ NLSDA/BP86/DN*

number of shells: $\quad 242$

$153 \mathrm{~S}$ shells

$60 \mathrm{P}$ shells

29 D shells

number of valence orbitals: 478

point group symmetry used: $\mathrm{C} 1$

spin multiplicity: 
cartesian coordinates (angstroms)

\begin{tabular}{|c|c|c|c|c|}
\hline & & $\mathrm{X}$ & $\mathrm{y}$ & Z \\
\hline $\mathrm{O} 1$ & 1 & -0.0965149 & -2.1166162 & 2.9514823 \\
\hline $\mathrm{C} 1$ & 2 & 1.0404906 & -4.2034794 & 1.3885115 \\
\hline $\mathrm{H} 1$ & 3 & 2.2662955 & -5.8028184 & -1.3503280 \\
\hline $\mathrm{C} 2$ & 4 & 1.8684864 & -5.0002868 & -0.7350463 \\
\hline $\mathrm{C} 3$ & 5 & 1.5753325 & -5.2292423 & 0.6068835 \\
\hline $\mathrm{C} 4$ & 6 & 1.1291733 & -2.6995357 & -0.5105104 \\
\hline $\mathrm{C} 5$ & 7 & 0.8162154 & -2.9294620 & 0.8436927 \\
\hline C6 & 8 & 1.6256199 & -3.7481816 & -1.2982068 \\
\hline $\mathrm{H} 2$ & 9 & 2.4922748 & -0.9717911 & -2.4522564 \\
\hline H3 & 10 & 1.7481027 & -6.2103684 & 1.0415302 \\
\hline $\mathrm{C} 7$ & 11 & -0.2231259 & -2.8729335 & -3.5812603 \\
\hline Sil & 12 & -0.3419118 & 3.6712102 & -1.9635037 \\
\hline H4 & 13 & -1.2550704 & 4.7293990 & 4.3137951 \\
\hline $\mathrm{C} 8$ & 14 & 0.9251490 & -1.3588884 & -1.0953715 \\
\hline C9 & 15 & 1.4242199 & -1.2241653 & -2.5096770 \\
\hline $\mathrm{C} 10$ & 16 & 1.2517772 & -2.5321263 & -3.3047404 \\
\hline $\mathrm{O} 2$ & 17 & 1.8950300 & -3.6381302 & -2.6392478 \\
\hline H5 & 18 & -0.7150054 & -2.0776895 & -4.1513425 \\
\hline H6 & 19 & -0.7932223 & -3.0302424 & 00240 \\
\hline H7 & 20 & -0.3024044 & -3.8068309 & -4.1498441 \\
\hline H8 & 21 & 1.5551097 & -1.5689547 & -5.2507051 \\
\hline C11 & 22 & 1.9722836 & -2.3872009 & 4707 \\
\hline H9 & 23 & 1.9009071 & -3.3131151 & 70379 \\
\hline $\mathrm{H} 10$ & 24 & 3.0421969 & -2.1991996 & 072874 \\
\hline H11 & 25 & 0.9263510 & -0.4069008 & 7083 \\
\hline C12 & 26 & -2.1618330 & 3.8776390 & 5112 \\
\hline C13 & 27 & & 4.9292429 & 571 \\
\hline H12 & 28 & 1.1993463 & 4.8336957 & 87351 \\
\hline H13 & 29 & -3.4409855 & 2.7842115 & 34471 \\
\hline $\mathrm{H} 14$ & 30 & -2.3610987 & 4.8874645 & -2.7424106 \\
\hline H15 & 31 & 1.7430193 & 5882 & -3.3011592 \\
\hline $\mathrm{C} 14$ & 32 & -0.0367736 & -0.6368646 & 1.0459625 \\
\hline C15 & 33 & 0.3473062 & -0.38 & 3018 \\
\hline C16 & 34 & -0.6884818 & 0.4032866 & 1.7842382 \\
\hline $\mathrm{C} 17$ & 35 & 0.2362861 & -1.8219104 & 1.6392577 \\
\hline C18 & 36 & 0.6745838 & 3.9685188 & -3.5123500 \\
\hline H16 & 37 & -0.0321762 & 5.9467443 & -1.0202878 \\
\hline H17 & 38 & -4.0420659 & 2.7462370 & 1.7697365 \\
\hline H18 & 39 & 0.4080197 & 3.2515491 & -4.2947221 \\
\hline H19 & 40 & -2.7797498 & 3.7117619 & -1.4839770 \\
\hline C19 & 41 & 0.9342216 & -1.6906940 & 3.8438572 \\
\hline $\mathrm{H} 20$ & 42 & 1.0541491 & -0.6027777 & 3.8289456 \\
\hline $\mathrm{H} 21$ & 43 & 1.8871797 & -2.1773387 & 3.6094651 \\
\hline $\mathrm{H} 22$ & 44 & 0.6426188 & -1.9850975 & 4.8563157 \\
\hline $\mathrm{C} 20$ & 45 & -1.2326290 & 1.2900667 & 2.3842444 \\
\hline $\mathrm{Si} 2$ & 46 & -2.0461266 & 2.6318672 & 3.2459197 \\
\hline $\mathrm{C} 21$ & 47 & -3.2851994 & 3.4611969 & 2.1059790 \\
\hline $\mathrm{C} 22$ & 48 & -2.9413785 & 1.9722432 & 4.7566268 \\
\hline $\mathrm{C} 23$ & 49 & -0.7723164 & 3.8990292 & 3.7899338 \\
\hline $\mathrm{C} 24$ & 50 & 0.1420279 & 0.9146452 & -0.9071543 \\
\hline $\mathrm{C} 25$ & 51 & -0.0419524 & 2.0154589 & -1.3504587 \\
\hline $\mathrm{H} 23$ & 52 & 0.7938640 & -4.4108800 & 2.4271993 \\
\hline & 53 & -2.7859295 & 3.8717733 & 1.2235474 \\
\hline & 54 & -0.4483622 & 4.7877214 & 0.2537656 \\
\hline
\end{tabular}




$\begin{array}{rrrrr}\mathrm{H} 26 & 55 & -3.6986192 & 1.2368669 & 4.4685763 \\ \mathrm{H} 27 & 56 & -2.2395265 & 1.4899397 & 5.4436513 \\ \mathrm{H} 28 & 57 & 0.5004796 & 4.9769035 & -3.8995340 \\ \mathrm{H} 29 & 58 & -0.2360954 & 4.3049621 & 2.9269474 \\ \mathrm{H} 30 & 59 & -2.4699146 & 3.1639599 & -3.1414979 \\ \mathrm{H} 31 & 60 & -0.0407297 & 3.4471089 & 4.4664475 \\ \mathrm{H} 32 & 61 & -3.7943936 & 4.2806282 & 2.6219632\end{array}$

stoichiometry: $\quad \mathrm{Si} 2 \mathrm{O} 2 \mathrm{C} 25 \mathrm{H} 32$

molecular charge $\quad 0.0$

number of electrons $\quad 226.0$

integration mesh: $\quad$ FINE

integration points and checksum: 244496225.999963

$\mathrm{E}(\mathrm{DFT})=\quad-1701.78933 \quad$ BP86

total time: $83 \mathrm{~min} .19 .3 \mathrm{sec}$.

end Fri Jul 2 07:35:48 2004

Vinyl Carbene Intermediate (E)-50

molecule with a large size: set TOLG $=0.0008$

begin Fri Jul 2 02:26:28 2004 on boys

run type: ENERGY

model: $\quad$ NLSDA/BP86/DN*

number of shells: $\quad 300$

$182 \mathrm{~S}$ shells

79 P shells

39 D shells

number of valence orbitals: 614

point group symmetry used: $\mathrm{C} 1$

spin multiplicity: $\quad 1$

cartesian coordinates (angstroms)

\begin{tabular}{|c|c|c|c|c|}
\hline & atom & $\mathrm{x}$ & $\mathrm{y}$ & \\
\hline $\mathrm{O} 1$ & 1 & 1.6087019 & -1.3544871 & 1.4960855 \\
\hline $\mathrm{C} 1$ & 2 & -0.4845546 & -1.9847807 & -1.0586285 \\
\hline H1 & 3 & -1.3391235 & -1.4452452 & -0.6293064 \\
\hline $\mathrm{C} 2$ & 4 & 0.8107089 & -1.6715296 & -0.6353372 \\
\hline 5 & 5 & 0.3267312 & -3.6825953 & -2.5650769 \\
\hline $\mathrm{C} 4$ & 6 & 1.8913834 & -2.3927395 & -1.1822747 \\
\hline C5 & 7 & -0.7235873 & -2.9702822 & -2.0104999 \\
\hline C6 & 8 & 1.6317290 & -3.3884400 & -2.1441049 \\
\hline C7 & 9 & 3.2823446 & -2.1972272 & -0.8043975 \\
\hline $\mathrm{H} 2$ & 10 & -1.7516503 & -3.1875489 & -2.3192046 \\
\hline C8 & 11 & 4.4723381 & -3.2113066 & -3.8689042 \\
\hline H3 & 12 & 0.1436679 & -4.4644156 & -3.3106524 \\
\hline C9 & 13 & 4.2553798 & -2.8653713 & -1.4306069 \\
\hline H4 & 14 & 3.5097960 & -1.5023605 & 0.0122404 \\
\hline H5 & 15 & 5.3093887 & -2.7365846 & -1.1616575 \\
\hline $\mathrm{C} 10$ & 16 & 3.9806356 & -3.8256373 & -2.5501266 \\
\hline O2 1 & 17 & 2.5917174 & -4.1805524 & -2.7216090 \\
\hline & 18 & 5.5470367 & -2.9957567 & -3.8171281 \\
\hline
\end{tabular}




\begin{tabular}{|c|c|c|c|c|}
\hline H7 & 19 & 3.9534604 & -2.2709574 & -4.0939701 \\
\hline $\mathrm{H} 8$ & 20 & 4.3080633 & -3.8916891 & -4.7146800 \\
\hline H9 & 21 & 5.7890589 & -4.9942765 & -2.2233454 \\
\hline 11 & 22 & 4.7042601 & -5.1519155 & -2.2796989 \\
\hline $\mathrm{H} 10$ & 23 & .5155914 & -5.8844731 & -3.0757580 \\
\hline H11 & 24 & 4.3815623 & -5.6006758 & -1.3317332 \\
\hline & 25 & 1.3558486 & 1.5154368 & -0.1686511 \\
\hline 12 & 26 & -5.5260675 & 2.0236190 & 0.4942296 \\
\hline 13 & 27 & 3.2031669 & & 0.3510918 \\
\hline C14 & 28 & 1.2367318 & & -1.1105860 \\
\hline $\mathrm{C} 15$ & 29 & & & \\
\hline 16 & 30 & 1.99 & 24 & 303 \\
\hline 17 & 31 & -0.18 & & 4286 \\
\hline 18 & 32 & -0.5 & & 4547 \\
\hline 19 & 33 & -0.95 & & 76677 \\
\hline 20 & 34 & 0.9681684 & 6165 & 23557 \\
\hline $\mathrm{C} 21$ & 35 & -4.7627475 & 5577 & 4534 \\
\hline $\mathrm{O} 3$ & 36 & 4.312 & & \\
\hline $\mathrm{O} 4$ & 37 & & & \\
\hline $\mathrm{O} 5$ & 38 & & & \\
\hline O6 & 39 & 1.1 & 4.1 & -1. \\
\hline $\mathrm{C} 22$ & 40 & 1.84 & -0.7 & 4703 \\
\hline H12 & 41 & 0.922 & -0.5 & 5731 \\
\hline 1 & 42 & & & \\
\hline 14 & 43 & 2.4 & & 5822 \\
\hline $\mathrm{C} 23$ & 44 & -1.71 & & 2820 \\
\hline & 45 & -2.90 & & \\
\hline 24 & 46 & & & 063 \\
\hline 25 & 47 & -2.1 & & 968 \\
\hline $\mathrm{C} 26$ & 48 & -3.5 & 4646 & 15914 \\
\hline 27 & 49 & -1.8 & 328 & -0.6 \\
\hline $\mathrm{C} 28$ & 50 & -2.9 & & 99344 \\
\hline Si2 & 51 & -4.636 & 2.27 & -1.1633556 \\
\hline $\mathrm{C} 29$ & 52 & & & 43131 \\
\hline & 53 & & & \\
\hline 16 & 54 & & & \\
\hline 17 & 55 & -4.8 & 9084 & 36717 \\
\hline H18 & 56 & -4.2414614 & 4.2465925 & -2.6523225 \\
\hline H19 & 57 & -4.87 & 1.2554283 & -3.4389514 \\
\hline $\mathrm{H} 20$ & 58 & -1.2871306 & & 61141 \\
\hline $\mathrm{H} 21$ & 59 & -5.8093195 & 4.3692628 & -1.8410607 \\
\hline $\mathrm{H} 22$ & 60 & & & -0.9589699 \\
\hline $\mathrm{H} 23$ & 61 & & & 6.5829501 \\
\hline $\mathrm{H} 24$ & 62 & & & \\
\hline $\mathrm{H} 2$ & 63 & -4.24 & 1.9956732 & 5.2378228 \\
\hline & 64 & -6.4450989 & 3962511 & -2.6424243 \\
\hline & 65 & -4.0428216 & -1.9306442 & 3.4286228 \\
\hline $\mathrm{H} 28$ & 66 & -5.4626997 & 0.9811236 & 0.8216500 \\
\hline $\mathrm{H} 29$ & 67 & -2.6880350 & 2.6213582 & 4.6891986 \\
\hline $\mathrm{H} 30$ & 68 & -5.3345863 & 0.0962997 & -2.1857359 \\
\hline $\mathrm{H} 31$ & 69 & -6.5827471 & 2.2899801 & 0.4077223 \\
\hline & 70 & -3.9856928 & 2.3344430 & 3.5196135 \\
\hline
\end{tabular}

stoichiometry: $\mathrm{CrSi} 2 \mathrm{O} 6 \mathrm{C} 29 \mathrm{H} 32$

molecular charge $\quad 0.0$

number of electrons $\quad 306.0$

integration mesh: FINE

integration points and checksum: $289670 \quad 305.999931$ 
$\mathrm{E}(\mathrm{DFT})=-3200.00162 \quad \mathrm{BP} 86$

total time: $1215 \mathrm{~min} .34 .5 \mathrm{sec}$.

end Fri Jul 2 23:34:24 2004

\section{Vinyl Carbene Intermediate (Z)-50}

begin Fri Jul 2 02:20:46 2004 on coulson molecule with a large size: set $\mathrm{TOLG}=0.0008$ run type: $\quad$ ENERGY model: $\quad$ NLSDA/BP86/DN* number of shells: $\quad 300$

182 S shells 79 P shells 39 D shells

number of valence orbitals: 614 point group symmetry used: $\mathrm{C} 1$ spin multiplicity: cartesian coordinates (angstroms)

$\begin{array}{lcccc} & \text { atom } & \mathrm{x} & \mathrm{y} & \mathrm{z} \\ \mathrm{C} 1 & 1 & -2.5828728 & -0.1387778 & -1.4714217 \\ \mathrm{C} 1 & 2 & -2.7338234 & 0.8946847 & 1.5133320 \\ \mathrm{H} 1 & 3 & -2.9932084 & -0.1387518 & 1.7207849 \\ \mathrm{C} 2 & 4 & -1.9906621 & 1.2254840 & 0.3641470 \\ \text { C3 } & 5 & -2.8215250 & 3.2005674 & 2.1699331 \\ \mathrm{C} 4 & 6 & -1.6788046 & 2.5976799 & 0.0994435 \\ \mathrm{C} 5 & 7 & -3.1444116 & 1.8733284 & 2.4124193 \\ \text { C6 } & 8 & -2.1073887 & 3.5584732 & 1.0217758 \\ \text { C7 } & 9 & -0.9437573 & 3.0421718 & -0.9951284 \\ \text { H2 } & 10 & -3.7084338 & 1.6002848 & 3.2999006 \\ \text { C8 } & 11 & -0.5248775 & 6.5910271 & -0.0968448 \\ \text { H3 } & 12 & -3.1268757 & 3.9714903 & 2.8730470 \\ \text { C9 } & 13 & -0.7602101 & 4.3997159 & -1.2015022 \\ \text { H4 } & 14 & -0.4993762 & 2.3561306 & -1.7062538 \\ \text { H5 } & 15 & -0.2209599 & 4.7231727 & -1.9848530 \\ \text { C10 } & 16 & -1.4707760 & 5.4173286 & -0.3443828 \\ \text { O2 } & 17 & -1.8261327 & 4.8967622 & 0.9372285 \\ \text { H6 } & 18 & -0.2183495 & 7.0632222 & -1.0356302 \\ \text { H7 } & 19 & 0.3797978 & 6.2478991 & 0.4173328 \\ \text { H8 } & 20 & -0.9898963 & 7.3469277 & 0.5453187 \\ \text { H9 } & 21 & -2.4928877 & 6.3387071 & -2.0325311 \\ \text { C11 } & 22 & -2.7327754 & 5.8952608 & -1.0608742 \\ \text { H10 } & 23 & -3.2749462 & 6.6311644 & -0.4573163 \\ \text { H11 } & 24 & -3.4197281 & 5.0602695 & -1.2369408 \\ \text { Cr1 } & 25 & -1.3183510 & -2.4164880 & -0.1750770 \\ \text { C12 } & 26 & 4.0374878 & -5.0214531 & -0.8481405 \\ \text { C13 } & 27 & -3.2394543 & -2.6432703 & 0.5990394 \\ \text { C14 } & 28 & -0.5626849 & -4.3686106 & 0.0714200 \\ \text { C15 } & 29 & -0.6614093 & -2.1279916 & 1.8266826 \\ \text { C16 } & 30 & -2.1747748 & -3.1687300 & -1.9743778 \\ \text { C17 } & 31 & -0.2691436 & -0.2789135 & -0.5641275 \\ \text { C18 } & 32 & 0.0433699 & -1.5246541 & -1.1473102 \\ \text { C19 } & 33 & 0.7449044 & 0.4035656 & 0.1936032\end{array}$




$\begin{array}{lcccc}\text { C20 } & 34 & -1.5759486 & 0.0765478 & -0.5237475 \\ \text { C21 } & 35 & 4.6651360 & -3.2835724 & -3.2864690 \\ \text { O3 } & 36 & -4.2977817 & -2.7683345 & 1.0286232 \\ \text { O4 } & 37 & -2.6336689 & -3.5709358 & -2.9480445 \\ \text { O5 } & 38 & -0.3076004 & -1.9696221 & 2.9083301 \\ \text { O6 } & 39 & -0.1491970 & -5.4323342 & 0.2050081 \\ \text { C22 } & 40 & -2.2233797 & 0.0737660 & -2.8326368 \\ \text { H12 } & 41 & -1.4038505 & -0.5679594 & -3.1641295 \\ \text { H13 } & 42 & -1.9705013 & 1.1228992 & -3.0059723 \\ \text { H14 } & 43 & -3.0979876 & -0.1611495 & -3.4468756 \\ \text { C23 } & 44 & 1.5599058 & 1.0095810 & 0.8343771 \\ \text { Si1 } & 45 & 2.7036886 & 1.9648004 & 1.8281173 \\ \text { C24 } & 46 & 2.3465520 & 1.6870417 & 3.6475856 \\ \text { C25 } & 47 & 4.4625278 & 1.4322935 & 1.4512952 \\ \text { C26 } & 48 & 2.5062560 & 3.7869706 & 1.4277834 \\ \text { C27 } & 49 & 1.3307368 & -2.0820947 & -1.3141633 \\ \text { C28 } & 50 & 2.4287290 & -2.5558095 & -1.4215504 \\ \text { Si2 } & 51 & 4.0703975 & -3.2657893 & -1.5076031 \\ \text { C29 } & 52 & 5.2528012 & -2.2386309 & -0.4725345 \\ \text { H15 } & 53 & 4.6948649 & 1.5805482 & 0.3924009 \\ \text { H16 } & 54 & 3.3583865 & -5.6446962 & -1.4377362 \\ \text { H17 } & 55 & 3.7005016 & -5.0385667 & 0.1927333 \\ \text { H18 } & 56 & 3.2050471 & 4.3893212 & 2.0157725 \\ \text { H19 } & 57 & 3.0365610 & 2.2656387 & 4.2689645 \\ \text { H20 } & 58 & 5.2929294 & -1.2079762 & -0.8377948 \\ \text { H21 } & 59 & 4.6060496 & 0.3737401 & 1.6880112 \\ \text { H22 } & 60 & 5.1762717 & 2.0138937 & 2.0423148 \\ \text { H23 } & 61 & 3.9961182 & -3.8806870 & -3.9134018 \\ \text { H24 } & 62 & 2.4570142 & 0.6300397 & 3.9079435 \\ \text { H25 } & 63 & 4.7013028 & -2.2687091 & -3.6938053 \\ \text { H26 } & 64 & 4.9341941 & -2.2187246 & 0.5740455 \\ \text { H27 } & 65 & 1.4902633 & 4.1242340 & 1.6544744 \\ \text { H28 } & 66 & 2.7000989 & 3.9755455 & 0.3675627 \\ \text { H29 } & 67 & 6.2632984 & -2.6558670 & -0.5143831 \\ \text { H30 } & 68 & 1.3257074 & 1.9948633 & 3.8936066 \\ \text { H31 } & 69 & 5.0352544 & -5.4682510 & -0.8913926 \\ \text { H32 } & 70 & 5.6689874 & -3.7137011 & -3.3526230 \\ & & & & \end{array}$

stoichiometry: CrSi2O6C29H32

molecular charge $\quad 0.0$

number of electrons $\quad 306.0$

integration mesh: $\quad$ FINE

integration points and checksum: 288254305.999860

$\mathrm{E}(\mathrm{DFT})=\quad-3199.92118 \quad \mathrm{BP} 86$

total time: $1192 \mathrm{~min} .36 .8 \mathrm{sec}$.

end Fri Jul 2 23:02:58 2004

\section{Vinyl Ketene Complex 51}

begin Sun Jul 4 23:17:47 2004 on fermi molecule with a large size: set TOLG $=0.0008$

run type: $\quad$ ENERGY

model: $\quad$ NLSDA/BP86/DN*

number of shells: $\quad 300$

$182 \mathrm{~S}$ shells 
79 P shells

39 D shells

number of valence orbitals: 614

point group symmetry used: $\mathrm{Cl}$

spin multiplicity:

1

cartesian coordinates (angstroms)

\begin{tabular}{|c|c|c|c|c|}
\hline & ato & $\mathrm{X}$ & $y$ & \\
\hline $\mathrm{O} 1$ & 1 & 0.1104374 & 1.7625960 & 1.3139668 \\
\hline $\mathrm{C} 1$ & 2 & 1.2003705 & -0.0216680 & -1.7408761 \\
\hline $\mathrm{C} 2$ & 3 & 0.9143847 & 0.9714033 & -0.8574200 \\
\hline H1 & 4 & 2.1388394 & -0.6824083 & -3.6087592 \\
\hline $\mathrm{H} 2$ & 5 & 1.0141135 & -1.0799828 & -1.6184478 \\
\hline $\mathrm{C} 3$ & 6 & 1.6340238 & 2.3158829 & -1.1589094 \\
\hline H3 & 7 & 3.0616845 & 1.5366055 & -4.1586924 \\
\hline $\mathrm{C} 4$ & 8 & 2.4894241 & 1.3707251 & -3.2527477 \\
\hline H4 & 9 & 3.7360367 & -4.4365974 & -0.8771739 \\
\hline C5 & 10 & 1.9977774 & 0.1682689 & -2.9512963 \\
\hline C6 & 11 & 1.6270394 & 5.6138031 & -2.8718165 \\
\hline C7 & 12 & 2.3091107 & 2.4638581 & -2.3332666 \\
\hline Si1 & 13 & 2.1433748 & -4.8496847 & 0.9844034 \\
\hline $\mathrm{C} 8$ & 14 & 3.8138286 & -4.4823572 & 0.2132669 \\
\hline C9 & 15 & 2.2416780 & 4.6309467 & -0.6630227 \\
\hline $\mathrm{C} 10$ & 16 & 2.6876161 & 4.8398569 & -2.0827059 \\
\hline $\mathrm{O} 2$ & 17 & 2.9481898 & 3.6026449 & -2.7687404 \\
\hline H5 & 18 & 1.4304120 & 6.5982500 & -2.4332847 \\
\hline H6 & 19 & 0.6807821 & 5.0615680 & -2.9099582 \\
\hline H7 & 20 & 1.9422116 & 5.7548022 & -3.9122461 \\
\hline H8 & 21 & 3.9152102 & 6.5999364 & -1.6313286 \\
\hline $\mathrm{C} 11$ & 22 & 4.0112253 & 5.6130544 & -2.0973233 \\
\hline H9 & 23 & 4.3706382 & 5.7511285 & -3.1239489 \\
\hline H10 & 24 & 4.7956379 & 5.0574949 & -1.5690800 \\
\hline $\mathrm{Cr} 1$ & 25 & -1.0878433 & 0.0812667 & -1.4046654 \\
\hline $\mathrm{C} 12$ & 26 & 2.3277053 & -4.9272398 & 2.8500100 \\
\hline $\mathrm{C} 13$ & 27 & -1.4092550 & -0.9365719 & -3.2544756 \\
\hline $\mathrm{C} 14$ & 28 & -3.1205130 & 0.6165917 & -0.9474027 \\
\hline C15 & 29 & -1.2553496 & 1.8687633 & -2.6427472 \\
\hline C16 & 30 & -0.6201370 & -0.3997826 & 0.6958381 \\
\hline $\mathrm{O} 3$ & 31 & -2.8789355 & -2.5452067 & -0.8388384 \\
\hline $\mathrm{C} 17$ & 32 & -1.2142682 & -0.4946205 & 2.0184691 \\
\hline $\mathrm{C} 18$ & 33 & 0.0582487 & 0.7247323 & 0.3529883 \\
\hline C19 & 34 & 1.5226919 & -6.5037584 & 0.3553220 \\
\hline O4 & 35 & -1.5756657 & -1.4852218 & -4.2499647 \\
\hline $\mathrm{C} 20$ & 36 & -0.7145079 & -1.6212305 & -0.0683627 \\
\hline $\mathrm{O} 5$ & 37 & -1.3467253 & 2.8115924 & -3.2930068 \\
\hline $\mathrm{O} 6$ & 38 & -4.2030906 & 0.9080083 & -0.6967908 \\
\hline $\mathrm{C} 21$ & 39 & -1.0430348 & 2.6089296 & 1.2320924 \\
\hline H1 1 & 40 & -0.9065261 & 3.4203960 & 1.9534278 \\
\hline H12 & 41 & -1.9605478 & 2.0788337 & 1.5018227 \\
\hline H13 & 42 & -1.1429000 & 3.0576378 & 0.2389121 \\
\hline C22 & 43 & -1.7116042 & -0.5949971 & 3.1075014 \\
\hline $\mathrm{Si} 2$ & 44 & -2.4581368 & -0.7425807 & 4.7300807 \\
\hline & 45 & -2.4581619 & 0.9310957 & 5.5785540 \\
\hline$(26$ & 46 & -4.2248733 & -1.3496268 & 4.5633922 \\
\hline & 47 & -1.4806663 & -1.9620822 & 5.7679250 \\
\hline & 48 & 0.2039708 & -2.6843576 & 0.2630171 \\
\hline
\end{tabular}




$\begin{array}{rrrrr}\mathrm{C} 27 & 49 & 0.9802120 & -3.5564614 & 0.5469313 \\ \mathrm{H} 14 & 50 & 2.3246859 & 5.4575212 & 0.0361325 \\ \mathrm{C} 28 & 51 & 1.7752281 & 3.4481465 & -0.2450103 \\ \mathrm{H} 15 & 52 & -4.2543977 & -2.3288005 & 4.0759988 \\ \mathrm{H} 16 & 53 & 1.5530972 & 3.3363576 & 0.8058153 \\ \mathrm{C} 29 & 54 & -1.8611422 & -2.0201770 & -0.5345042 \\ \mathrm{H} 17 & 55 & 1.3669181 & -5.1452391 & 3.3260393 \\ \mathrm{H} 18 & 56 & 2.6963979 & -3.9750722 & 3.2432744 \\ \mathrm{H} 19 & 57 & -0.4459768 & -1.6272199 & 5.8882346 \\ \mathrm{H} 20 & 58 & -1.4370970 & 1.3063673 & 5.6959390 \\ \mathrm{H} 21 & 59 & -2.9120624 & 0.8595251 & 6.5714714 \\ \mathrm{H} 22 & 60 & -3.0264813 & 1.6615759 & 4.9949019 \\ \mathrm{H} 23 & 61 & 4.5370188 & -5.2616739 & 0.4715800 \\ \mathrm{H} 24 & 62 & -1.4683112 & -2.9497036 & 5.2970654 \\ \mathrm{H} 25 & 63 & -1.9244830 & -2.0636657 & 6.7627959 \\ \mathrm{H} 26 & 64 & 2.2237540 & -7.3025274 & 0.6153086 \\ \mathrm{H} 27 & 65 & -4.8201716 & -0.6520871 & 3.9665023 \\ \mathrm{H} 28 & 66 & 3.0356107 & -5.7113530 & 3.1347768 \\ \mathrm{H} 29 & 67 & 4.2030709 & -3.5237466 & 0.5693086 \\ \mathrm{H} 30 & 68 & 1.4116311 & -6.4883316 & -0.7330801 \\ \mathrm{H} 31 & 69 & -4.6944167 & -1.4438265 & 5.5471251 \\ \mathrm{H} 32 & 70 & 0.5507143 & -6.7465194 & 0.7952301\end{array}$

stoichiometry: $\mathrm{CrSi} 2 \mathrm{O} 6 \mathrm{C} 29 \mathrm{H} 32$

molecular charge $\quad 0.0$

number of electrons $\quad 306.0$

integration mesh: FINE

integration points and checksum: 291002305.999806

$\mathrm{E}(\mathrm{DFT})=\quad-3199.89670 \quad \mathrm{BP} 86$

total time: $1387 \mathrm{~min} .43 .1 \mathrm{sec}$.

end Mon Jul 5 23:15:49 2004

\section{Vinyl Ketene Intermediate $\mathbf{5 2}$}

begin Thu Jul 15 02:07:31 2004 on slater molecule with a large size: set TOLG $=0.0008$

run type: ENERGY

model: $\quad$ NLSDA/BP86/DN*

number of shells: $\quad 300$

$182 \mathrm{~S}$ shells

79 P shells

39 D shells

number of valence orbitals: 614

point group symmetry used: $\mathrm{C} 1$

spin multiplicity: $\quad 1$

cartesian coordinates (angstroms)

$\begin{array}{ccccc} & \text { atom } & \mathrm{x} & \mathrm{y} & \mathrm{z} \\ & & & & \\ \text { O1 } & 1 & -0.2496463 & 2.1637712 & 0.8827959 \\ \mathrm{C} 1 & 2 & -2.4954894 & 0.0368931 & 1.5455640 \\ \text { H1 } & 3 & -1.9902477 & 0.1536964 & 2.5039046 \\ \text { C2 } & 4 & -1.8405322 & 0.2797106 & 0.3178032 \\ \text { C3 } & 5 & -4.4985183 & -0.6013637 & 0.3797995\end{array}$




\begin{tabular}{|c|c|c|c|c|}
\hline 4 & 6 & 2.5313789 & & \\
\hline & 7 & -3.8173787 & -0.3986046 & \\
\hline & 8 & -3.8643463 & -0.3777310 & -0.8435258 \\
\hline & 9 & 0.3815569 & 2.2606076 & 5.5278885 \\
\hline & 10 & & & 5187527 \\
\hline & 11 & & & \\
\hline & 12 & 313107 & & 0.3950417 \\
\hline & 13 & 2.4282000 & & \\
\hline & 14 & 73540 & & 7107 \\
\hline & 15 & & & 1955 \\
\hline 10 & 16 & & & 31251 \\
\hline & 17 & & & \\
\hline & 18 & & & \\
\hline & 19 & & & \\
\hline & 20 & & & \\
\hline & 21 & & & \\
\hline & 22 & & & \\
\hline & 23 & & & \\
\hline & 24 & & & \\
\hline & 25 & & & \\
\hline & 26 & & & \\
\hline 13 & 27 & & & \\
\hline 11 & 28 & & & \\
\hline 14 & 29 & & & \\
\hline & 30 & & & \\
\hline & 31 & & & \\
\hline 16 & 32 & & & \\
\hline & 33 & & & \\
\hline & 34 & & & \\
\hline & 35 & & & \\
\hline 19 & 36 & & & \\
\hline & 37 & & & 176 \\
\hline & 38 & & & \\
\hline 21 & 39 & & & \\
\hline & 40 & & & \\
\hline & 41 & & & \\
\hline & 42 & & & \\
\hline 22 & 43 & & & \\
\hline & 44 & -0.1 & & \\
\hline & 45 & & & \\
\hline & 46 & & & \\
\hline 25 & 47 & & & \\
\hline 26 & 48 & & & \\
\hline & 49 & & & \\
\hline & 50 & & & \\
\hline & 51 & & & \\
\hline & 52 & & & \\
\hline & 53 & & & \\
\hline & 54 & & & \\
\hline 19 & 55 & & & 5.0260805 \\
\hline H2O & 56 & -0.8146532 & 83518 & 2635589 \\
\hline & 57 & & & \\
\hline & 58 & & & \\
\hline & 59 & & & \\
\hline & 60 & & & \\
\hline & 61 & & 0.0789139 & \\
\hline & & & & \\
\hline & & & & \\
\hline
\end{tabular}




$\begin{array}{lllll}\mathrm{H} 27 & 64 & 2.2041849 & -5.0426343 & -1.1330450 \\ \mathrm{H} 28 & 65 & 0.8854018 & 1.4789703 & 7.0369201 \\ \mathrm{H} 29 & 66 & 0.2623181 & -5.3788166 & 1.2736148 \\ \mathrm{H} 30 & 67 & -1.4436157 & -4.9289231 & 1.1006685 \\ \mathrm{H} 31 & 68 & -1.8689074 & -5.2312217 & -2.4300981 \\ \mathrm{H} 32 & 69 & 3.2832768 & 3.2194907 & 5.0448508 \\ \mathrm{O} 6 & 70 & 0.6537097 & 3.8598305 & -3.0776563\end{array}$

stoichiometry: CrSi2O6C29H32

molecular charge $\quad 0.0$

number of electrons $\quad 306.0$

integration mesh: $\quad$ FINE

integration points and checksum: 289682305.999993

$\mathrm{E}(\mathrm{DFT})=-3199.90603 \quad \mathrm{BP} 86$

total time: $1390 \mathrm{~min} .32 .2 \mathrm{sec}$.

end Fri Jul 16 03:40:13 2004

\section{Chromacyclohexadiene Intermediate 53}

begin Mon Mar 28 16:50:57 2005 on pauling

molecule with a large size: set TOLG $=0.0008$

run type: ENERGY

model: $\quad$ NLSDA/BP86/DN*

number of shells: $\quad 288$

$176 \mathrm{~S}$ shells

$75 \mathrm{P}$ shells

$37 \mathrm{D}$ shells

number of valence orbitals: 586

point group symmetry used: $\mathrm{C} 1$

spin multiplicity:

cartesian coordinates (angstroms)

\begin{tabular}{|c|c|c|c|c|}
\hline & ato & $\mathrm{x}$ & $\mathrm{y}$ & Z \\
\hline H1 & 1 & 0.0980289 & -0.9955483 & -5.4332225 \\
\hline $\mathrm{C} 1$ & 2 & -0.2934327 & -0.7242888 & -4.4464331 \\
\hline $\mathrm{H} 2$ & 3 & 1.2431570 & 0.7054626 & -3.9219981 \\
\hline $\mathrm{C} 2$ & 4 & 0.3007633 & 0.1741803 & -3.6427278 \\
\hline $\mathrm{C} 3$ & 5 & -1.9314122 & -1.2953456 & -2.6696622 \\
\hline $\mathrm{C} 4$ & 6 & -0.2894094 & 0.5125132 & -2.3204112 \\
\hline C5 & 7 & -1.5198854 & -1.3626831 & -3.9731641 \\
\hline C6 & 8 & -1.1572828 & -0.5249479 & -1.6927172 \\
\hline C7 & 9 & 3.3567259 & 0.9335543 & -2.2707274 \\
\hline $\mathrm{O} 1$ & 10 & -2.1571184 & -2.0630622 & -4.9612505 \\
\hline $\mathrm{O} 2$ & 11 & -2.2139962 & -1.4978263 & 0.1870505 \\
\hline $\mathrm{C} 8$ & 12 & -3.1394312 & -2.0033879 & -2.2971055 \\
\hline C9 & 13 & 0.9248520 & 0.4711002 & 0.3924421 \\
\hline C10 & 14 & 1.8172638 & -1.3172665 & -1.4952665 \\
\hline C11 & 15 & 1.7858458 & 0.9892042 & 1.3887389 \\
\hline C12 & 16 & -0.3267341 & -0.0191430 & 0.6546245 \\
\hline C13 & 17 & -0.8362425 & 0.1059377 & 1.9756964 \\
\hline C14 & 18 & -1.2051600 & -0.6801417 & -0.3345195 \\
\hline C15 & 19 & -3.4767919 & -2.5942656 & -4.6868790 \\
\hline
\end{tabular}




\begin{tabular}{|c|c|c|c|c|}
\hline $\mathrm{C} 16$ & 20 & -3.8669233 & -2.6170117 & -3.2362274 \\
\hline H3 & 21 & -3.3813302 & -2.0041299 & -1.2171704 \\
\hline H4 & 22 & -2.7520685 & -4.6608124 & -4.6855254 \\
\hline H5 & 23 & -4.7869652 & -3.1589453 & -2.9958992 \\
\hline $\mathrm{C} 17$ & 24 & -3.4573509 & -4.0266166 & -5.2372834 \\
\hline $\mathrm{C} 18$ & 25 & -4.4861787 & -1.7388225 & \\
\hline H6 & 26 & -3.1676427 & -4.0497954 & \\
\hline & 27 & -5.4996967 & -2.1451822 & -5.3566645 \\
\hline $\mathrm{H} 8$ & 28 & -4.2501106 & -1.7110012 & \\
\hline H9 & 29 & -4.5015705 & $-0.7038^{\prime}$ & -5.1012637 \\
\hline H10 & 30 & & & \\
\hline C19 & 31 & & & \\
\hline $\mathrm{Cr} 1$ & 32 & $1.5 \mathrm{~s}$ & & \\
\hline $\mathrm{O} 3$ & 33 & 4.41 & & \\
\hline $\mathrm{O} 4$ & 34 & & & \\
\hline & 35 & 1.9 & -2.45 & \\
\hline $\mathrm{C} 20$ & 36 & -1.7439112 & & \\
\hline 11 & 37 & -2.6686694 & & \\
\hline 12 & 38 & & & \\
\hline 13 & 39 & & & \\
\hline 14 & 40 & & & \\
\hline 21 & 41 & -1. & & \\
\hline 22 & 42 & & 702 & 629 \\
\hline & 43 & -1.8 & & \\
\hline $\mathrm{Si} 2$ & 44 & 3.52 & & \\
\hline $\mathrm{C} 23$ & 45 & -3.6 & & \\
\hline 24 & 46 & & & \\
\hline 25 & 47 & & & \\
\hline 26 & 48 & & & \\
\hline 27 & 49 & & 0.6 & \\
\hline 28 & 50 & & & \\
\hline 15 & 51 & 0.2895090 & -0.2 & 0573 \\
\hline 16 & 52 & -0.8188549 & 23009 & 5.6218190 \\
\hline 17 & 53 & & & \\
\hline 18 & 54 & & & \\
\hline 9 & 55 & & & \\
\hline ) & 56 & -3.7 & -1.0 & \\
\hline 2 & 57 & -0.53 & & 4379 \\
\hline & 58 & & & \\
\hline H23 & 59 & -2.1321754 & 2.9547222 & 4.5313982 \\
\hline H24 & 60 & 5.4144098 & & 4.8517974 \\
\hline H25 & 61 & & & \\
\hline H26 & 62 & & & \\
\hline & 63 & & & \\
\hline & 64 & & & \\
\hline & 65 & & & \\
\hline & 66 & & & 3.7972563 \\
\hline H31 & 67 & 3.6971926 & 4.3638768 & 2.7279358 \\
\hline H32 & 68 & 5.0456816 & 3.3909306 & 2.1237391 \\
\hline
\end{tabular}

stoichiometry: $\mathrm{CrSi} 2 \mathrm{O} 5 \mathrm{C} 28 \mathrm{H} 32$

molecular charge $\quad 0.0$

number of electrons $\quad 292.0$

integration mesh: $\quad$ FINE

integration points and checksum: 281088291.999960

$\mathrm{E}(\mathrm{DFT})=\quad-3086.53678 \quad \mathrm{BP} 86$

total time: $322 \mathrm{~min} .0 .7 \mathrm{sec}$. 
end Mon Mar 28 22:29:19 2005

\section{Indene 54}

begin Fri Apr 1 15:27:02 2005 on pauling run type: ENERGY model: $\quad$ NLSDA/BP86/DN*

number of shells: $\quad 242$

$153 \mathrm{~S}$ shells

$60 \mathrm{P}$ shells

29 D shells

number of valence orbitals: 478

point group symmetry used: $\mathrm{C} 1$

spin multiplicity:

1

cartesian coordinates (angstroms)

\begin{tabular}{|c|c|c|c|c|}
\hline & atol & $\mathrm{x}$ & $\mathrm{y}$ & \\
\hline H1 & 1 & -1.7080639 & 2.1927644 & 4.2069794 \\
\hline $\mathrm{C} 1$ & 2 & -1.5596350 & 1.4151215 & 3.4489066 \\
\hline $\mathrm{H} 2$ & 3 & -1.3119358 & 2.8187959 & 1.8182132 \\
\hline $\mathrm{C} 2$ & 4 & -1.3412103 & 1.7669124 & 2.1205436 \\
\hline C3 & 5 & -1.4131063 & -0.9747964 & 2.8675143 \\
\hline $\mathrm{C} 4$ & 6 & -1.1510572 & 0.7636137 & 1.1859379 \\
\hline C5 & 7 & -1.5916004 & 0.0609178 & 3.8115508 \\
\hline C6 & 8 & -1.1764452 & -0.6028631 & 1.5445393 \\
\hline H3 & 9 & 1.2369850 & 4.2336776 & -3.6466067 \\
\hline $\mathrm{O} 1$ & 10 & -1.8627143 & -0.1642280 & 5.1390393 \\
\hline $\mathrm{O} 2$ & 11 & -0.8655305 & -2.7440254 & 0.4047445 \\
\hline C7 & 12 & -1.5000975 & -2.3435914 & 3.3448842 \\
\hline C8 & 13 & -0.9260454 & 0.9061643 & -0.2988411 \\
\hline H4 & 14 & 1.9503864 & 5.4963889 & -0.8600552 \\
\hline C9 & 15 & 0.2061312 & 1.7230866 & -0.6599461 \\
\hline $\mathrm{C} 10$ & 16 & -0.7434417 & -0.5401532 & -0.7446104 \\
\hline C11 & 17 & -0.3876133 & -0.8091811 & -2.0744429 \\
\hline $\mathrm{C} 12$ & 18 & -0.9126284 & -1.3831841 & 0.3168485 \\
\hline $\mathrm{C} 13$ & 19 & -1.5861303 & -1.4778482 & 5.6748458 \\
\hline C14 & 20 & -1.5874135 & -2.5831533 & 4.6572421 \\
\hline H5 & 21 & -1.4996965 & -3.1599092 & 2.6153850 \\
\hline H6 & 22 & -3.6837195 & -1.7753369 & 6.2297206 \\
\hline H7 & 23 & -1.6514790 & -3.6006825 & 5.0567311 \\
\hline C15 & 24 & -2.6962770 & -1.7211651 & 6.7055422 \\
\hline C16 & 25 & -0.2162908 & -1.4374934 & 6.3668638 \\
\hline H8 & 26 & -2.7326545 & -0.9210641 & 7.4568361 \\
\hline H9 & 27 & 0.0011730 & -2.3991247 & 6.8485863 \\
\hline H10 & 28 & -0.1797880 & -0.6594281 & 7.1406083 \\
\hline H11 & 29 & 0.5902615 & -1.2326232 & 5.6513429 \\
\hline H12 & 30 & -2.5280893 & -2.6672772 & 7.2361282 \\
\hline H13 & 31 & 3.8939662 & 1.2073367 & -2.2643654 \\
\hline H14 & 32 & 1.8787795 & 2.6445037 & -4.0908244 \\
\hline H15 & 33 & 4.9196081 & 2.6313790 & -2.0224274 \\
\hline
\end{tabular}




$\begin{array}{lcccc}\text { H16 } & 34 & 4.2378498 & 1.7837763 & -0.6260070 \\ \mathrm{H} 17 & 35 & 2.9506969 & 4.0557745 & -4.0518356 \\ \mathrm{C} 17 & 36 & -0.6093896 & -3.4558641 & -0.7846833 \\ \mathrm{H} 18 & 37 & -0.6278027 & -4.4938768 & -0.4429057 \\ \mathrm{H} 19 & 38 & 0.3705287 & -3.2076174 & -1.2088858 \\ \mathrm{H} 20 & 39 & -1.3870847 & -3.2849769 & -1.5380097 \\ \mathrm{H} 21 & 40 & 3.0313729 & 4.6457533 & 0.2515931 \\ \mathrm{C} 18 & 41 & -0.0247806 & -0.9320048 & -3.2120763 \\ \mathrm{C} 19 & 42 & 1.1425777 & 2.3640471 & -1.0416736 \\ \mathrm{~S} 11 & 43 & 0.6078495 & -0.9855526 & -4.8438631 \\ \mathrm{~S} 2 & 44 & 2.5060205 & 3.2182313 & -1.7358007 \\ \mathrm{C} 20 & 45 & 0.2118853 & -2.6514004 & -5.6528554 \\ \mathrm{C} 21 & 46 & -0.1566409 & 0.4320510 & -5.8449525 \\ \mathrm{C} 22 & 47 & 2.4865292 & -0.7283513 & -4.7493850 \\ \mathrm{C} 23 & 48 & 2.1034505 & 3.5740688 & -3.5566822 \\ \mathrm{C} 24 & 49 & 2.8198065 & 4.8362707 & -0.8037307 \\ \mathrm{C} 25 & 50 & 4.0373682 & 2.1027960 & -1.6516269 \\ \mathrm{H} 22 & 51 & 0.1585793 & 1.3992686 & -5.4411944 \\ \mathrm{H} 23 & 52 & -1.2481968 & 0.3921769 & -5.8181639 \\ \mathrm{H} 24 & 53 & 0.1600259 & 0.3800794 & -6.8900584 \\ \mathrm{H} 25 & 54 & 0.6612356 & -3.4759994 & -5.0935700 \\ \mathrm{H} 26 & 55 & 0.6002247 & -2.6835258 & -6.6745229 \\ \mathrm{H} 27 & 56 & -0.8672092 & -2.8204473 & -5.6954860 \\ \mathrm{H} 28 & 57 & 2.7203139 & 0.2209944 & -4.2551770 \\ \mathrm{H} 29 & 58 & 2.9240789 & -0.7088153 & -5.7509085 \\ \mathrm{H} 30 & 59 & 2.9664225 & -1.5306382 & -4.1836168 \\ \mathrm{H} 31 & 60 & 3.6758831 & 5.3658523 & -1.2309074 \\ \mathrm{H} 32 & 61 & -1.8385459 & 1.3373470 & -0.7798503 \\ & & & & \end{array}$

stoichiometry: $\mathrm{Si} 2 \mathrm{O} 2 \mathrm{C} 25 \mathrm{H} 32$

molecular charge $\quad 0.0$

number of electrons $\quad 226.0$

integration mesh: $\quad$ FINE

integration points and checksum: $244652 \quad 225.999933$

$\mathrm{E}(\mathrm{DFT})=\quad-1701.74846 \quad \mathrm{BP} 86$

total time: $\quad 89 \mathrm{~min} .24 .6 \mathrm{sec}$.

end Fri Apr 1 17:10:30 2005

\section{Chelated Carbene Complex 55}

begin Fri Jul 2 02:19:44 2004 on pauling molecule with a large size: set $\mathrm{TOLG}=0.0008$

run type: ENERGY

model: $\quad$ NLSDA/BP86/DN*

number of shells: $\quad 300$

$182 \mathrm{~S}$ shells

79 P shells

39 D shells

number of valence orbitals: 614

point group symmetry used: $\mathrm{C} 1$

spin multiplicity: $\quad 1$

cartesian coordinates (angstroms) 


\begin{tabular}{|c|c|c|c|c|}
\hline & ator & $\mathrm{x}$ & y & \\
\hline $\mathrm{O} 1$ & 1 & 1.1724348 & -2.2066183 & 2.7187272 \\
\hline $\mathrm{C} 1$ & 2 & 1.6769303 & 0.6810203 & 3.3723629 \\
\hline H1 & 3 & 2.5771651 & 0.0890465 & 3.5225523 \\
\hline $\mathrm{C} 2$ & 4 & 0.6042795 & 0.1628180 & 2.6348119 \\
\hline C3 & 5 & 0.5039811 & 2.7822719 & 3.6058162 \\
\hline $\mathrm{C} 4$ & 6 & -0.5562041 & 0.9469729 & 2.4488992 \\
\hline $\mathrm{C} 5$ & 7 & 1.6195221 & 1.9847661 & 3.8669054 \\
\hline C6 & 8 & -0.5782281 & 2.2672311 & 2.8909905 \\
\hline C7 & 9 & -1.6394848 & 0.4537313 & 1.7321485 \\
\hline H2 & 10 & 2.4596992 & 2.3945263 & 4.4214618 \\
\hline $\mathrm{C} 8$ & 11 & -3.5129083 & 3.6653698 & 1.2868318 \\
\hline H3 & 12 & 0.4763025 & 3.8122717 & 3.9514232 \\
\hline C9 & 13 & -2.5968834 & 1.3179592 & 1.2546489 \\
\hline H4 & 14 & -1.7797661 & -0.6211106 & 1.6282988 \\
\hline H5 & 15 & -3.4323899 & 0.8990887 & 0.8939682 \\
\hline $\mathrm{C} 10$ & 16 & -2.8255683 & 2.5804979 & 2.1146304 \\
\hline $\mathrm{O} 2$ & 17 & -1.6048592 & 3.1364229 & 2.6339257 \\
\hline H6 & 18 & -4.4597751 & 3.3085510 & 0.8698424 \\
\hline H7 & 19 & -2.8816545 & 3.9962284 & 0.4590560 \\
\hline H8 & 20 & -3.7117110 & 4.5553192 & 1.8947186 \\
\hline H9 & 21 & -4.6945881 & 1.8238889 & 2.9570593 \\
\hline $\mathrm{C} 11$ & 22 & -3.7342705 & 2.2214561 & 3.3009152 \\
\hline H10 & 23 & -3.9175936 & 3.0959452 & 3.9349224 \\
\hline H11 & 24 & -3.2698007 & 1.4629294 & 3.9400137 \\
\hline Cr1 & 25 & -1.5514381 & 0.5931662 & -0.5708013 \\
\hline $\mathrm{C} 12$ & 26 & 4.6988267 & 0.6978589 & -3.2295463 \\
\hline $\mathrm{C} 13$ & 27 & -3.2913003 & 1.5359547 & -1.4434722 \\
\hline C14 & 28 & -1.1234486 & 0.4005623 & -2.7017452 \\
\hline C15 & 29 & -2.5508552 & -1.2499016 & -0.7595889 \\
\hline C16 & 30 & -0.7592069 & 2.5759537 & -0.5691568 \\
\hline C17 & 31 & 0.5613831 & -1.2742840 & 0.5922976 \\
\hline $\mathrm{C} 18$ & 32 & 0.2555397 & -0.1603279 & -0.3093225 \\
\hline C19 & 33 & 0.7117585 & -2.5541159 & -0.0304550 \\
\hline $\mathrm{C} 20$ & 34 & 0.7494267 & -1.1438705 & 1.9324899 \\
\hline $\mathrm{C} 21$ & 35 & 2.9149227 & 3.1650873 & -3.5198753 \\
\hline $\mathrm{O} 3$ & 36 & -4.2195861 & 2.0283173 & -1.9088545 \\
\hline $\mathrm{O} 4$ & 37 & -0.3221869 & 3.6390966 & -0.5876460 \\
\hline O5 & 38 & -3.0981982 & -2.2555118 & -0.8562121 \\
\hline O6 & 39 & -0.9019177 & 0.2972392 & -3.8247277 \\
\hline $\mathrm{C} 22$ & 40 & 0.1762717 & -2.6075435 & 3.6577439 \\
\hline H12 & 41 & -0.7780659 & -2.8092959 & 3.1588347 \\
\hline H13 & 42 & 0.0455092 & -1.8553331 & 4.4421383 \\
\hline H14 & 43 & 0.5151649 & -3.5335943 & 4.1313505 \\
\hline $\mathrm{C} 23$ & 44 & 0.8197248 & -3.6242419 & -0.5642864 \\
\hline Sil & 45 & 0.9761350 & -5.2189392 & -1.3660623 \\
\hline C24 & 46 & 2.5489758 & -5.2682446 & -2.3868206 \\
\hline $\mathrm{C} 25$ & 47 & 1.0338947 & -6.5777150 & -0.0737336 \\
\hline C26 & 48 & -0.4988900 & -5.5027088 & -2.4920974 \\
\hline $\mathrm{C} 27$ & 49 & 1.3485564 & 0.4822189 & -0.9670212 \\
\hline $\mathrm{C} 28$ & 50 & 2.2626317 & 1.0387554 & -1.5116770 \\
\hline Si2 & 51 & 3.6080173 & 1.9129839 & -2.3058121 \\
\hline C29 & 52 & 4.6342002 & 2.8070347 & -1.0149276 \\
\hline H15 & 53 & 4.1257450 & 0.1668107 & -3.9955524 \\
\hline H16 & 54 & 3.4275908 & -5.1123143 & -1.7536537 \\
\hline H17 & 55 & 5.1221462 & -0.0423170 & -2.5438878 \\
\hline H18 & 56 & -1.4317680 & -5.4848873 & -1.9205633 \\
\hline
\end{tabular}




$\begin{array}{rrrrr}\text { H19 } & 57 & 2.3157691 & 2.6685350 & -4.2890817 \\ \mathrm{H} 20 & 58 & 5.4596613 & 3.3487709 & -1.4862868 \\ \mathrm{H} 21 & 59 & 0.1222795 & -6.5765930 & 0.5313729 \\ \mathrm{H} 22 & 60 & 5.5252615 & 1.2192672 & -3.7216962 \\ \mathrm{H} 23 & 61 & -0.4216190 & -6.4736798 & -2.9903430 \\ \mathrm{H} 24 & 62 & 4.0223789 & 3.5283382 & -0.4647634 \\ \mathrm{H} 25 & 63 & -0.5537505 & -4.7268594 & -3.2616809 \\ \mathrm{H} 26 & 64 & 1.1263591 & -7.5584229 & -0.5498962 \\ \mathrm{H} 27 & 65 & 2.6548315 & -6.2366665 & -2.8848602 \\ \mathrm{H} 28 & 66 & 2.2782847 & 3.8916167 & -3.0059404 \\ \mathrm{H} 29 & 67 & 1.8890219 & -6.4409189 & 0.5950149 \\ \mathrm{H} 30 & 68 & 3.7240262 & 3.7098274 & -4.0154549 \\ \mathrm{H} 31 & 69 & 5.0569626 & 2.0984051 & -0.2963781 \\ \mathrm{H} 32 & 70 & 2.5377467 & -4.4889562 & -3.1548127 \\ & & & & \end{array}$

stoichiometry: $\mathrm{CrSi} 2 \mathrm{O} 6 \mathrm{C} 29 \mathrm{H} 32$

molecular charge $\quad 0.0$

number of electrons $\quad 306.0$

integration mesh: FINE

integration points and checksum: 290126305.999982

$\mathrm{E}(\mathrm{DFT})=\quad-3199.93292 \quad$ BP86

total time: $242 \mathrm{~min} .25 .4 \mathrm{sec}$.

end Fri Jul 2 08:05:12 2004

\section{$[2+2]$ Cycloaddition Product 56}

begin Fri Jul 2 02:24:50 2004 on fermi molecule with a large size: set TOLG $=0.0008$ run type: ENERGY model: $\quad$ NLSDA/BP86/DN*

number of shells: $\quad 300$

$182 \mathrm{~S}$ shells

79 P shells

39 D shells

number of valence orbitals: 614

point group symmetry used: $\mathrm{C} 1$

spin multiplicity: $\quad 1$

cartesian coordinates (angstroms)

$\begin{array}{lcccc} & \text { atom } & \mathrm{x} & \mathrm{y} & \mathrm{z} \\ \mathrm{O} 1 & 1 & -2.0934452 & -1.9981357 & 2.6379586 \\ \mathrm{C} 1 & 2 & -1.9316645 & -3.9122532 & 0.4189062 \\ \mathrm{H} 1 & 3 & -0.6026204 & -5.3725315 & -2.3796480 \\ \mathrm{C} 2 & 4 & -0.7101678 & -4.6762001 & -1.5417563 \\ \mathrm{C} 3 & 5 & -1.7553534 & -4.8102163 & -0.6320592 \\ \mathrm{C} 4 & 6 & 0.0670255 & -2.7737805 & -0.2684832 \\ \mathrm{C} 5 & 7 & -1.0206803 & -2.8704810 & 0.6073955 \\ \mathrm{C} 6 & 8 & 0.2005400 & -3.6283971 & -1.3622100 \\ \mathrm{H} 2 & 9 & 3.0216913 & -1.5985258 & -0.9715792 \\ \mathrm{H} 3 & 10 & -2.4690018 & -5.6315763 & -0.7575431 \\ \mathrm{C} 7 & 11 & 0.5191513 & -1.4602251 & -3.3710351 \\ \text { Si1 } & 12 & -2.3197850 & 1.3156723 & -2.6871455\end{array}$




\begin{tabular}{|c|c|c|c|c|}
\hline 14 & 13 & 1.6908169 & -2.0748740 & \\
\hline 8 & 14 & 1.0750783 & & \\
\hline & 15 & 1.9665127 & -1.3217868 & \\
\hline 10 & 16 & 1.6237170 & -2.0819023 & -2.5117497 \\
\hline & 17 & & -3.4730349 & -2.2477662 \\
\hline & 18 & & & \\
\hline & 19 & & & \\
\hline & 20 & & & -4.2567027 \\
\hline & 21 & & & -3.6040047 \\
\hline 11 & 22 & & & 720366 \\
\hline & 23 & 2.66 & & \\
\hline & 24 & & & \\
\hline & 25 & & & \\
\hline & 26 & & & \\
\hline & 27 & & & \\
\hline & 28 & & & \\
\hline & 29 & & & \\
\hline & 30 & & & \\
\hline 17 & 31 & & & \\
\hline & 32 & & & \\
\hline & 33 & & & \\
\hline & 34 & & & \\
\hline & 35 & & & \\
\hline & 36 & & & \\
\hline & 37 & & & \\
\hline & 38 & & & \\
\hline & 39 & & & \\
\hline & 40 & & & \\
\hline 23 & 41 & & & \\
\hline & 42 & & & \\
\hline & 43 & & & \\
\hline 13 & 44 & -2.5 & & \\
\hline 24 & 45 & -1.0 & & \\
\hline & 46 & -1.44 & & \\
\hline & 47 & & & \\
\hline & 48 & & & \\
\hline & 49 & & & \\
\hline & 50 & & & \\
\hline & 51 & & & \\
\hline & 52 & & & \\
\hline & 53 & & & \\
\hline & 54 & & & \\
\hline & 55 & & & \\
\hline & 56 & & & \\
\hline & 57 & & & \\
\hline & 58 & & & \\
\hline 21 & 59 & -2.8 & & 468 \\
\hline H22 & 60 & & & \\
\hline H23 & 61 & & & \\
\hline & 62 & & & \\
\hline & 63 & & & \\
\hline & 64 & & & \\
\hline & 65 & & & \\
\hline H28 & 66 & -0.7196853 & & -4.6168020 \\
\hline H29 & 67 & -4.0146399 & -0.4939830 & -2.3404185 \\
\hline H30 & 68 & -3.2731752 & 2.8267609 & 6.0332908 \\
\hline & 69 & & & -1.6508770 \\
\hline & & $-4.1 / 00900$ & 2.9813751 & -2.5516259 \\
\hline
\end{tabular}


stoichiometry: $\mathrm{CrSi} 2 \mathrm{O} 6 \mathrm{C} 29 \mathrm{H} 32$

molecular charge $\quad 0.0$

number of electrons $\quad 306.0$

integration mesh: $\quad$ FINE

integration points and checksum: 289622306.000058

$\mathrm{E}(\mathrm{DFT})=\quad-3199.98966 \quad \mathrm{BP} 86$

total time: $1034 \mathrm{~min} .16 .0 \mathrm{sec}$.

end Fri Jul 2 20:28:37 2004

\section{$\beta$-Hydride Elimination Intermediate $\mathbf{5 8}$}

begin Thu Mar 31 19:39:04 2005 on pauling molecule with a large size: set TOLG $=0.0008$ run type: $\quad$ ENERGY model: $\quad$ NLSDA/BP86/DN*

number of shells: $\quad 300$

$182 \mathrm{~S}$ shells

79 P shells

$39 \mathrm{D}$ shells

number of valence orbitals: 614

point group symmetry used: $\mathrm{C} 1$ spin multiplicity:

cartesian coordinates (angstroms)

\begin{tabular}{|c|c|c|c|c|}
\hline & ator & $\mathrm{x}$ & $\mathrm{y}$ & z \\
\hline $\mathrm{O} 1$ & 1 & 3.3367001 & -1.8348320 & -2.4193451 \\
\hline $\mathrm{C} 1$ & 2 & 2.0788062 & -0.4234605 & -4.5197300 \\
\hline H1 & 3 & -0.2156869 & 1.4901890 & -6.1172314 \\
\hline $\mathrm{C} 2$ & 4 & 0.3036783 & 0.9886777 & -5.3048803 \\
\hline C3 & 5 & 1.4513489 & 0.2515567 & -5.5629121 \\
\hline C4 & 6 & 0.4504422 & 0.4439668 & -2.9267832 \\
\hline $\mathrm{C} 5$ & 7 & 1.5858202 & -0.3387271 & -3.2042914 \\
\hline C6 & 8 & -0.2070176 & 1.0623789 & -4.0060430 \\
\hline $\mathrm{H} 2$ & 9 & -0.4849235 & 2.5924489 & -1.7517275 \\
\hline H3 & 10 & 1.8388948 & 0.1782586 & -6.5750411 \\
\hline C7 & 11 & -2.8942913 & 0.2612579 & -2.7336603 \\
\hline Si1 & 12 & -0.9637802 & -1.5703017 & 3.3741292 \\
\hline $\mathrm{H} 4$ & 13 & -0.3507459 & 1.9607724 & 0.8150481 \\
\hline $\mathrm{C} 8$ & 14 & -0.0799636 & 0.5723793 & -1.5202259 \\
\hline C9 & 15 & -1.0997206 & 1.7137050 & -1.4967088 \\
\hline $\mathrm{C} 10$ & 16 & -2.1207411 & 1.5889995 & -2.6635171 \\
\hline $\mathrm{O} 2$ & 17 & -1.3867782 & 1.7532843 & -3.9055045 \\
\hline H5 & 18 & -3.6143413 & 0.1614402 & -1.9199025 \\
\hline H6 & 19 & -2.2360494 & -0.6125993 & -2.7148144 \\
\hline H7 & 20 & -3.4493845 & 0.1945738 & -3.6775158 \\
\hline H8 & 21 & -3.9272349 & 2.6196243 & -1.9711782 \\
\hline $\mathrm{C} 11$ & 22 & -3.1377887 & 2.7355037 & -2.7155097 \\
\hline H9 & 23 & -3.6273130 & 2.7748111 & -3.6970363 \\
\hline H10 & 24 & -2.6489210 & 3.7071275 & -2.5848085 \\
\hline & 25 & -1.8989200 & 2.4718212 & 0.5102120 \\
\hline
\end{tabular}




$\begin{array}{lcccc}\mathrm{C} 12 & 26 & -1.2141128 & -3.4205564 & 3.1575096 \\ \mathrm{C} 13 & 27 & 0.4331773 & -1.2690364 & 4.5916692 \\ \mathrm{C} 14 & 28 & -3.6797333 & 3.6367240 & 0.4352607 \\ \mathrm{C} 15 & 29 & -1.8174771 & 2.7515049 & 2.6136378 \\ \mathrm{C} 16 & 30 & -0.8848898 & 4.3112721 & 0.1180577 \\ \mathrm{C} 17 & 31 & -3.1329741 & 0.7855008 & 0.6735419 \\ \mathrm{C} 18 & 32 & 1.5891736 & -1.1514070 & -0.9064086 \\ \mathrm{C} 19 & 33 & 0.3974942 & -0.3157418 & -0.6081089 \\ \mathrm{C} 20 & 34 & 2.1745396 & -1.9707373 & 0.1187618 \\ \mathrm{C} 21 & 35 & 2.2018970 & -1.1011543 & -2.1082840 \\ \mathrm{C} 22 & 36 & -2.5420779 & -0.8431083 & 4.0735551 \\ \mathrm{O} 3 & 37 & -4.6402502 & 4.2664904 & 0.3990132 \\ \mathrm{O} 4 & 38 & -3.8194411 & -0.1313791 & 0.7681046 \\ \mathrm{O} 5 & 39 & -0.3390856 & 5.3009948 & -0.0887624 \\ \mathrm{O} 6 & 40 & -1.7695907 & 2.9080106 & 3.7508937 \\ \mathrm{C} 23 & 41 & 4.5173416 & -1.0853732 & -2.1282655 \\ \mathrm{H} 11 & 42 & 4.5897967 & -0.8492144 & -1.0616310 \\ \mathrm{H} 12 & 43 & 4.5586400 & -0.1648189 & -2.7202542 \\ \mathrm{H} 13 & 44 & 5.3798243 & -1.7018377 & -2.3981616 \\ \mathrm{C} 24 & 45 & 2.7331435 & -2.6525590 & 0.9355395 \\ \mathrm{~S} 2 & 46 & 3.6816458 & -3.6669179 & 2.0672081 \\ \mathrm{C} 25 & 47 & 2.5593501 & -4.7900359 & 3.0610572 \\ \mathrm{C} 26 & 48 & 4.8954373 & -4.7202204 & 1.0934852 \\ \mathrm{C} 27 & 49 & 4.6447480 & -2.5652230 & 3.2450534 \\ \mathrm{C} 28 & 50 & -0.1652914 & -0.5120767 & 0.6947644 \\ \mathrm{C} 29 & 51 & -0.5389819 & -0.8452459 & 1.7885794 \\ \mathrm{H} 14 & 52 & 2.9490196 & -1.0358070 & -4.7448539 \\ \mathrm{H} 15 & 53 & 1.9055011 & -4.2073539 & 3.7156947 \\ \mathrm{H} 16 & 54 & 1.3720265 & -1.6852369 & 4.2167455 \\ \mathrm{H} 17 & 55 & 4.3652238 & -5.3827034 & 0.4027771 \\ \mathrm{H} 18 & 56 & 5.5744773 & -4.0897876 & 0.5115096 \\ \mathrm{H} 19 & 57 & -2.7728004 & -1.2955211 & 5.0429853 \\ \mathrm{H} 20 & 58 & 3.9669908 & -1.9381271 & 3.8317074 \\ \mathrm{H} 21 & 59 & -2.0887460 & -3.6189801 & 2.5306772 \\ \mathrm{H} 22 & 60 & 5.3259631 & -1.9108231 & 2.6929299 \\ \mathrm{H} 23 & 61 & 3.1491210 & -5.4649121 & 3.6887630 \\ \mathrm{H} 24 & 62 & 5.2375567 & -3.1694840 & 3.9381849 \\ \mathrm{H} 25 & 63 & -2.4481763 & 0.2350100 & 4.2209956 \\ \mathrm{H} 26 & 64 & -1.3699318 & -3.9044862 & 4.1261405 \\ \mathrm{H} 27 & 65 & 1.9333430 & -5.3988893 & 2.4019826 \\ \mathrm{H} 28 & 66 & -3.3889693 & -1.0288917 & 3.4074901 \\ \mathrm{H} 29 & 67 & -0.3436271 & -3.8776332 & 2.6798158 \\ \mathrm{H} 30 & 68 & 5.4954502 & -5.3381755 & 1.7680856 \\ \mathrm{H} 31 & 69 & 0.5765139 & -0.1970690 & 4.7575730 \\ \mathrm{H} 32 & 70 & 0.2120154 & -1.7376755 & 5.5551798\end{array}$

stoichiometry: CrSi2O6C29H32

molecular charge $\quad 0.0$

number of electrons $\quad 306.0$

integration mesh: $\quad$ FINE

integration points and checksum: $290426 \quad 305.999940$

$\mathrm{E}(\mathrm{DFT})=\quad-3199.92958 \quad \mathrm{BP} 86$

total time: $258 \mathrm{~min} .7 .6 \mathrm{sec}$.

end Fri Apr 1 00:10:21 2005 


\section{Carbon Monoxide}

begin Thu Mar 31 08:08:57 2005 on pauling

run type: $\quad$ ENERGY

model: $\quad$ NLSDA/BP86/DN*

number of shells: $\quad 12$

$6 \mathrm{~S}$ shells

$4 \mathrm{P}$ shells

2 D shells

number of valence orbitals: 28

point group symmetry used: $\mathrm{C} 2 \mathrm{~V}$

spin multiplicity:

cartesian coordinates (angstroms)

\begin{tabular}{ccccr} 
& atom & $\mathrm{x}$ & $\mathrm{y}$ & \multicolumn{2}{l}{$\mathrm{z}$} \\
& & & & \\
$\mathrm{O} 1$ & 1 & 0.0000000 & 0.0000000 & 0.4863107 \\
$\mathrm{C} 1$ & 2 & 0.0000000 & 0.0000000 & -0.6484143
\end{tabular}

stoichiometry: $\quad$ OC

molecular charge $\quad 0.0$

number of electrons $\quad 14.0$

integration mesh: FINE

integration points and checksum: $2266 \quad 14.000002$

$\mathrm{E}(\mathrm{DFT})=\quad-113.36183 \mathrm{BP} 86$

total time: $\quad 0 \mathrm{~min} .1 .0 \mathrm{sec}$.

end Thu Mar 31 08:08:59 2005

\section{Benzene}

begin Wed Jul 7 12:05:21 2004 on heitler

run type:

ENERGY

model: $\quad$ NLSDA/BP86/DN*

number of shells:

48

$30 \mathrm{~S}$ shells

12 P shells

6 D shells

number of valence orbitals: 96

point group symmetry used: $\mathrm{D} 2 \mathrm{H}$

spin multiplicity:

1

cartesian coordinates (angstroms)

\begin{tabular}{cccccc} 
& atom & $\mathrm{x}$ & $\mathrm{y}$ & \multicolumn{2}{l}{$\mathrm{z}$} \\
& & & & & \\
H1 & 1 & 0.0000000 & 0.0000000 & 2.4858122
\end{tabular}




$\begin{array}{lcccc}\mathrm{C} 1 & 2 & 0.0000000 & 0.0000000 & 1.3910772 \\ \mathrm{C} 2 & 3 & 0.0000000 & 1.2047082 & 0.6955386 \\ \mathrm{C} 3 & 4 & 0.0000000 & -1.2047082 & 0.6955386 \\ \mathrm{C} 4 & 5 & 0.0000000 & -1.2047082 & -0.6955386 \\ \mathrm{H} 2 & 6 & 0.0000000 & -2.1527765 & 1.2429060 \\ \mathrm{C} 5 & 7 & 0.0000000 & 0.0000000 & -1.3910772 \\ \mathrm{H} 3 & 8 & 0.0000000 & -2.1527765 & -1.2429060 \\ \mathrm{C} 6 & 9 & 0.0000000 & 1.2047082 & -0.6955386 \\ \mathrm{H} 4 & 10 & 0.0000000 & 0.0000000 & -2.4858122 \\ \mathrm{H} 5 & 11 & 0.0000000 & 2.1527765 & -1.2429060 \\ \mathrm{H} 6 & 12 & 0.0000000 & 2.1527765 & 1.2429060\end{array}$

$\begin{array}{lc}\text { stoichiometry: } & \text { C6H6 } \\ \text { molecular charge } & 0.0 \\ \text { number of electrons } & 42.0 \\ \text { integration mesh: } & \text { FINE }\end{array}$

integration points and checksum: $13336 \quad 42.000014$

$\mathrm{E}(\mathrm{DFT})=-232.31431 \quad \mathrm{BP} 86$

total time: $1 \mathrm{~min} .42 .6 \mathrm{sec}$.

end Wed Jul 7 12:07:15 2004

Benzenetricarbonyl Chromium Complex 64

begin Wed Jul 7 12:03:30 2004 on coulson

run type: ENERGY

model: $\quad$ NLSDA/BP86/DN*

number of shells: $\quad 94$

$53 \mathrm{~S}$ shells

27 P shells

14 D shells

number of valence orbitals: 204

point group symmetry used: CS

spin multiplicity:

1

cartesian coordinates (angstroms)

\begin{tabular}{|c|c|c|c|c|}
\hline \multicolumn{3}{|c|}{ atom } & \\
\hline $\mathrm{Cr} 1$ & 1 & -0.0001211 & 0.0000000 & 0.0923317 \\
\hline H1 & 2 & -2.1955801 & -1.2658256 & -1.6794619 \\
\hline $\mathrm{H} 2$ & 3 & 0.0012594 & -2.5341757 & -1.6796961 \\
\hline $\mathrm{H} 3$ & 4 & -2.1955801 & 1.2658256 & -1.6794619 \\
\hline H4 & 5 & 2.1938237 & 1.2683606 & -1.6801118 \\
\hline H5 & 6 & 2.1938237 & -1.2683606 & -1.6801118 \\
\hline H6 & 7 & 0.0012594 & 2.5341757 & -1.6796961 \\
\hline $\mathrm{C} 1$ & 8 & 0.0058182 & 1.4383732 & -1.6227906 \\
\hline $\mathrm{C} 2$ & 9 & 0.0058182 & -1.4383732 & -1.6227906 \\
\hline C3 & 10 & -1.2488763 & 0.7139708 & -1.6226942 \\
\hline C4 & 11 & 1.2425793 & 0.7243817 & -1.6230440 \\
\hline C5 & 12 & 1.2425793 & -0.7243817 & -1.6230440 \\
\hline C6 & 13 & -1.2488763 & -0.7139708 & -1.6226942 \\
\hline C7 & 14 & 1.5319270 & 0.0000000 & 1.2065111 \\
\hline C8 & 15 & -0.7658707 & -1.3264842 & 1.2068167 \\
\hline C9 & 16 & -0.7658707 & 1.3264842 & 1.2068167 \\
\hline $\mathrm{O} 1$ & 17 & -1.2516834 & -2.1683222 & 1.8571620 \\
\hline $\mathrm{O} 2$ & 18 & 2.5044332 & 0.0000000 & 1.8561832 \\
\hline $\mathrm{O} 3$ & 19 & -1.2516834 & 2.1683222 & 1.8571620 \\
\hline
\end{tabular}


stoichiometry: $\quad \mathrm{CrO} 3 \mathrm{C} 9 \mathrm{H} 6$

molecular charge $\quad 0.0$

number of electrons $\quad 108.0$

integration mesh: $\quad$ FINE

integration points and checksum: $43342 \quad 107.999995$

$\mathrm{E}(\mathrm{DFT})=\quad-1617.24843 \quad \mathrm{BP} 86$

total time: $23 \mathrm{~min} .16 .8 \mathrm{sec}$.

end Wed Jul 7 12:38:48 2004 